\title{
Energy
}

\section{SEPARATION, FRACTIONATION, CONCENTRATION AND DRYING OF FOOD PRODUCTS}

Technology Progress Report for the Period October 1, 1984-March 3, 1987

\author{
By \\ W. W. Rose \\ L. D. Pederson \\ C. A. Merlo \\ P. L. Brewbaker
}

November 1987

Work Performed Under Contract No. AC07-84ID12553

For

U. S. Department of Encrgy

Office of Industrial Programs

Washington, DC

By

National Food Processors Association

Dublin, California 


\section{DISCLAIMER}

This report was prepared as an account of work sponsored by an agency of the United States Government. Neither the United States Government nor any agency Thereof, nor any of their employees, makes any warranty, express or implied, or assumes any legal liability or responsibility for the accuracy, completeness, or usefulness of any information, apparatus, product, or process disclosed, or represents that its use would not infringe privately owned rights. Reference herein to any specific commercial product, process, or service by trade name, trademark, manufacturer, or otherwise does not necessarily constitute or imply its endorsement, recommendation, or favoring by the United States Government or any agency thereof. The views and opinions of authors expressed herein do not necessarily state or reflect those of the United States Government or any agency thereof. 


\section{DISCLAIMER}

Portions of this document may be illegible in electronic image products. Images are produced from the best available original document. 


\section{DISCLAIMER}

This report was prepared as an account of work sponsored by an agency of the Inited States Government. Neither the United States Government nor any agency thereof, nu diny of their emplnyees. makes any warranty, express or implied, or assumes any legal liability or responsibility for the accuracy, completencss, or use fulness of any information, apparatus, product, or process disclosed, or represents that its use would not infringe privately owned rights. Reference herein to any specific commercial product, process, or scrvice by trade name, trademark, manufacturer, or otherwise does not necessarily constitute or imply its endorsement, recommendation, or favoring by the United States Government or any agency thereof. The views and opinions of authors expressed herein do not necessarily state or reflect those of the United States Government or any agency thereof.

This report has been reproduced directly from the best available copy.

Available from the National Technical Information Service, U. S. Department of Commerce, Springfield, Virginia 22161.

Price: Printed Copy A06

Microfiche A01

Codes are used for pricing all publications. The code is determined by the number of pages in the publication. Information pertaining to the pricing codes can be found in the current issues of the following publications, which are generally available in most libraries: Energy Research Abstracts (ERA); Government Reports Announcements and Index (GRA and I); Scientific and Technical Abstract Reports (STAR), and publication NTIS-PR-360 available from NTIS at the above address. 


\section{Separation, fractionation, concentration and drying of food products: Technology progress report, October 1, 1984-March 3, 1987}

Rose, W.W.; Pederson, L.D.; Merlo, C.A.; Brewbaker, P.L.

Nov 1987

National Food Processors Association, Dublin, CA (USA)

Reproduced and Distributed by:

U.S. DEPARTMENT OF ENERGY

Office of Scieritific and Technlcal Information

P.O. Box 62

Oak Ridge, TN 37831 


\section{Department of Energy}

Washington, DC 20585

\section{FOR YOUR INFORMATION AND ACTION}

Techincal Progress Report - Separation, Concentration and Drying of Food Products (October 1, T984 to March 3, T987)

The National Food Processors Association has completed Phases I and II of an effort to develop more energy efficient technologies for processing, containerizing, and transporting juice products.

This on-going effort has been partly supported by the Department of Energy's Office of Industrial Programs and is reviewed in the enclosed report. The concept to separate foods and concentrate the components at one site and then recombine at another is novel and could be very effective in reducing energy consumption and various other costs in the food industry.

Please review the report and provide comments and recommendations by phone or writing to:

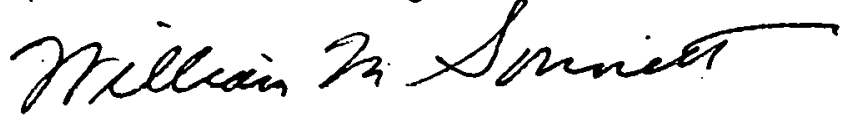

Mr. William M. Sonnett, PE

Program Manager

U.S. Department of Energy

CE-142 - Room 5F-043

1000 Independance Ave., SW

Washington, DC 20585

Phone - 202-586-2389

Your input will be greatly appreciated. 
DOE/ID/12553-1

(DE88006269)

Distribution Category UC-311

\title{
SEPARATION, FRACTIONATION, CONCENTRATION AND DRYING \\ OF FOOD PRODUCTS
}

Technology Progress Report

October 1, 1984 to March 3, 1987

by

W. W. Rose

L. D. Pederson

C. A. Merlo

P. L. Brewbaker

November 1987

Work Performed Under Contract No. DE-AC07-84ID12553

\author{
Prepared ror \\ U.S. Department of Energy \\ Idaho Operations Office, Idaho Falls, Idaho \\ Sponsored by the Office of the Assistant Secretary. for \\ Conservation and Renewable Energy \\ Office of Industrial Programs \\ Washington, DC
}

\author{
Prepared by \\ National Food Processors Association \\ 6363 Clark Avenue \\ Dublin, California 94568
}




\section{EXECUTIVE SUMMARY}

This study was undertaken to assess the potential for developing more energy efficient technology for processing, containerizing, and transporting of juice products.

Container manufacturing and product transportation consume significant energy in conjunction with food production. Evaporation is presently used to concentrate food products, especially juice products; however, a large fraction of the final product is water, which is packaged and shipped with the food product. For example, tomato paste, which is produced by concentrating tomato juice from $5 \%$ total solids to $30 \%$ total solids, is over 60\% water. Approximately 500,000 tons of tomato paste are produced, canned, and transported each year in the United states: In other words, over 300,000 tons of water are transported with tomato paste each year. Due to technical and economic limitations, evaporation cannot be used to further concentrate food products.

In this project, an advanced process is being investigted; this process, if successful, will greatly reduce the amount of water that must be packaged and shipped. with food products. The research is described below.

In Phase I of this project (described in detail in this report), tomato puree was fractionated by conventional vacuum filtration, centrifugation, and crossflow microfiltration to produce a pulp fraction and a serum fraction. The resulting fractions from each separation were chracterized. The pulp and serum fractions were recombined by homogenization, stomacher 
blending, and static (in-line) mixing; the viscosity of the resulting recombined tomato purees were determined and compared to the viscosity of the original puree. In this study, viscosity was used as the most important quality characteristic of tomato puree. Centrifugation (for fractionation) followed by homogenization (for recombination) produced a recombined puree with viscosity equivalent to that of the original puree. In subsequent phase I studies, the pulp fraction was rinsed with water to recover the soluble components of the pulp (producing a rinsed-pulp fraction) and the rinse water was added to the serum fraction (producing a rinse/serum fraction). The rinse/ serum fraction was then concentrated by vacuum evaporation to produce a concentrated-rinse/serum fraction (50\% and 21\% total solids (TS]). The resulting fractions were characterized. The rinsed-pulp and concentrated-rinse/serum fractions were recombined (with water) by homogenization; satisfactory puree was produced.

In Phase II (described in detail in this report), the following fractionation sequence was investigated. Puree was fractionated by centrifugation and the resulting pulp fraction was rinsed to produce a rinsed-pulp fraction. The rinse water was added to the serum fraction to produce a rinse/serum fraction. The rinse/serum fraction was 1) concentrated by vacuum evaporation to $13 \% \mathrm{TS}$, or 2) further fractionated by ultrafiltration (with a 100,000 molecular-weight-cutoff membrane) to produce a high-molecular weight (MW) fraction and a low/intermediate-MW fraction. The resulting low/intermediate-MW fraction was then further fractionated by ultrafiltration (with a 2000-MW-cutoff membrane) to produce a low-MW fraction and an intermediate-MW fraction. 
The low-MW fraction was treated by anion exchange to separate organic acids from sugars. The organic acid salts were recovered. from the anion exchange resin and were regenerated by cation exchange.

The low/intermediate-MW fraction (pre-ion-exchange) was concentrated by vacuum evaporation to $74 \%$ TS.

Recombined puree was produced by homogenizing concentrated rinse/serum ( $13 \%$ TS) with pulp and water, and by homogenizing concentrated low/intermediate-MW fraction, :high-MW fraction, pulp and water. The viscosity of these purees was close to the baseline puree; colors were lighter and yellower.

Phase II also included fractionation/recombination studies using fresh tomato juice. In the fresh juice studies, a puree containing $11 \%$ TS was produced by vacuum evaporation to serve as a baseline so that the viscosity measurement commoniy used by industry (Bostwick) could be used to assess product quality. The fresh juice was centrifuged to produce a pulp fraction and a serum fraction. The pulp fraction was not rinsed in the fresh juice studies. The serum fraction was concentrated by vacuum evaporation to $13 \%$ and $70 \%$ TS. A satisfactory recombined puree was produced upon homogenizing the pulp, concentrated serum (70\% TS), and water, or upon static mixing or homogenizing the pulp, concentrated serum (13\% TS) and water.

Phase II also included product stability tests, in which recombined puree (made with $13 \%$ TS serum from fresh juice) was canned and stored (under refrigeration) and the cans were opened at one, four and eight months to examine the recombined puree for quality stability. Quality was stable for the samples studied. 


\section{ABSTRACT}

This report describes the first and second phases of a three phase project, the object of which is to develop energy efficient separation, concentration, and drying processes for food products, especially juice products, in order to reduce energy requirements and their associated costs for processing, preservation, and transportation. Presently in juice processing, much water is eliminated through evaporation. However, there are significant limits to the current evaporation technology. If, however, the juice could be separated, prior to evaporation, into liquid and solid fractions, and the liquid concentrated further, the containerization and transportation costs could be significantly reduced.

In the first phase of this study, tomato puree was separated by three methods: conventional vacuum filtration, centrifugation, and crossflow microfiltration, producing pulp and serum fractions. The greatest separation by weight was obtained by centrifugation. The separated fractions were characterized. The clearest serum was obtained by microporous filtration. The separated fractions were recombined by three techniques (static mixing, stomacher blending, and homogenizing) and evaluated. The iecumblned puree consistently regained viscosity when homogenized, and in some cases, when static mixed.

In a subsequent part of the first phase tomato puree was separated by centrifugation and the pulp fraction was rinsed producing a rinsed-pulp fraction. The rinse water was added to the serum fraction producing a rinse/serum fraction. The rinse/serum fraction was concentrated by vacuum evaporation to 
30, 50, and $70 \%$ total solids (TS). These fractions were characterized. Rinsing the pulp successfully lowered the sugar content of the rinsed-pulp.

The concentrated rinse/serum (50\% and $21 \%$ TS) and rinsed pulp were recombined with the addition of water by homogenization, producing satisfactory puree.

The relation of viscosity to protein and pectin content of ripening tomatocs was also examined. The percent protein in the serum more closely followed the changes in viscosity than did percent pectin.

In the second phase, tomato puree was centrifuged to produce a pulp fraction and a serum fraction. The pulp fraction was rinsed producing a rinsed-pulp fraction and a rinse/serum fraction. The rinse/serum was then fractionated into high- and low/intermediate-MW (molecular weight) fractions by ultraliltration with membranes of 100,000-MW-cutoff. The permeate stream (low/intermediate-MW fraction) from this ultrafiltration was then ultrafiltered with membranes of 2000-MW-cutoff producing intermediate- and low-MW (permeate) fractions. The low-MW fraction was treated by weak base anion exchange to remove organic acids from the fraction. The organic acid salts were recovered from the anion exchange resin and regenerated by cation exchange.

The low/intermediate-MW traction was concenliated by varumm evaporation to $74 \%$ TS. Satisfactory recombined puree was made by homogenizing rinsed pulp, concentrated low/intermediate-Mw fraction, high-MW fraction, and water. Satisfactory recombined 
puree was also made by homogenizing concentrated rinse/serum (13\% TS) with rinsed pulp and water.

The second phase also included studies with fresh tomato juice. The juice was centrifuged into pulp and serum. Puree was made by vacuum evaporating juice to provide a baseline to compare with previous puree studies. Serum was concentrated by vacuum evaporation to $13 \%$ and $70 \%$ TS. A recombined puree was made by homogenizing pulp, concentrated serum (70\% TS), and water, or by static mixing the pulp, concentrated serum (13\% TS) and water. The viscosity was satisfactorily restored. The recombined puree (made with $13 \%$ Ts serum) was canned and stored 8 months (under refrigeration) and quality was stable. 


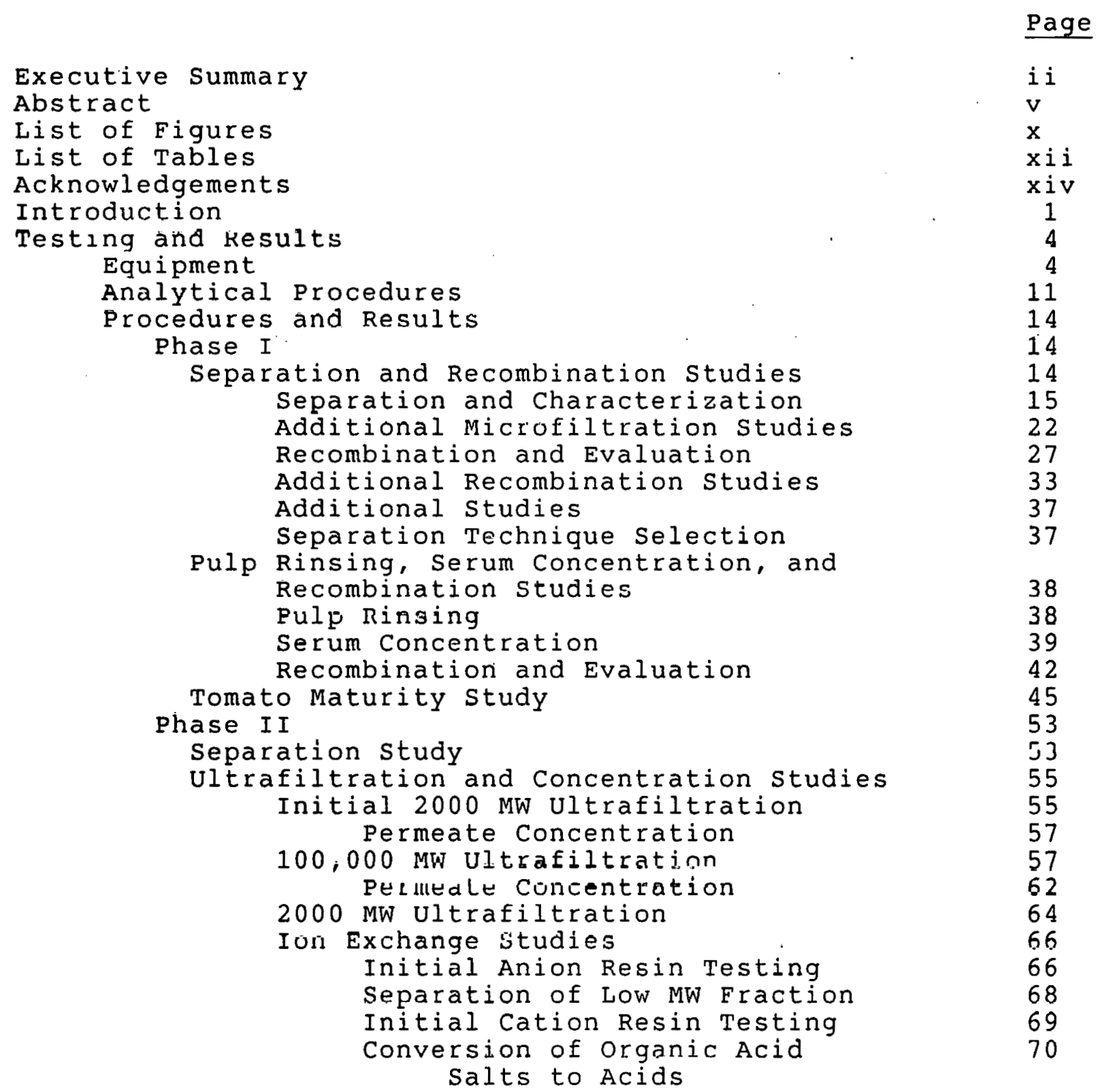


TABLE OF CONTENTS (Continued)

Page

Mass Balance

Recombination studies

Second Level Recombination

75

First Level Recombination

77

77

79

Pulp Drying studies

79

Drying of Rinsed Pulp

80

Hygroscopy of Dried Pulp $\quad 82$

Fresh Juice Studies

85

Puree Production

85

Serum Concentration 85

$\begin{array}{ll}\text { Recombination } & 87\end{array}$

$\begin{aligned} \text { Recombination with Low } & 87 \\ \text { Level Solids Serum } & 87\end{aligned}$

Recombination with High

Level Solids Serum $\quad 89$

Storage Effects

Recombined Product storage

91

High Level Solids Serum Storage

91

Ultrafiltration of serum

Conclusions and Recommendations

93

93

101

References

Appendix A - Abbreviations

102

103

Appendix B - Metric to English Conversion Table

104 
No.

$\underline{\text { Page }}$

1 Separation, fractionation and concentration schematic

2 Recirculation mode operation 5

3 Batch mode operation 5

4 Continuous mode operation 9

5 High pertormance llquid chromatogram of organic acids for three samples and a standard. The samples: original puree, microfiltered pulp, and microflltered serum contained respectively: 0.91 , 0.94 , and $0.86 \%$ citric acid.

6 Microporous filter(0.2 micron)--Flux versus pressure and flow

8 Microporous filter(1.0 micron)--Flux, temperature, and $\frac{\circ}{6}$ solids of permeate versus operating time

9 Bostwick viscosity (cm) versus stomacher mixing time(min) for unseparated puree (10.8\% NTSS)

10 Bostwick viscosity $(\mathrm{cm})$ versus homogenizing time (min) on unseparated puree $(10.2 \%$ NTSS $)$

11 Bostwick viscosity $(\mathrm{cm})$ versus homogenizing time (min) on unseparated puree $(9.2 \%$ NTSS $)$

12 Percent protein in serum versus maturity stage (Bradford method)

13 Libby's efflux viscosity versus maturity stage

14 Serum viscosity versus maturity stage (Ostwald method)

15 Precipitate weight ratio versus maturity stage 


\section{$x i$ \\ LIST OF FIGURES (CON'T.}

No.

Page

16 Percent pectin in serum versus maturity stage (carbazole/ $\mathrm{H}_{2} \mathrm{SO}_{4}$ method)

17 Flux versus time - 100,000 MW ultrafiltration of rinse/serum

18 NTSS (\%) versus time - 100,000 MW ultrafiltration of rinse/serum

19 Pressure drop versus time - 100,000 MW ultrafiltration of rinse/serum

20 pH vs. throughput for cation resin C-391b using NaOH regenerant from anion resin $A-399 b$ as feed

21 pH vs. throughput for cation resin C-391b using effluent $>\mathrm{pH} 2$ (in Figure 8) plus "sweeten-off" backwash of resin in Figure 8 ; second feed is "NaOH-off" backwash from anion resin $A-399 b$

$22 \mathrm{pH}$ vs. throughput for cation resin C-391b using $\mathrm{NaOH}$ regenerant from anion resin SM-73 as feed

$23 \mathrm{pH}$ vs. throughput for cation resin C-391b using effluent $>\mathrm{pH} 2$ (in Figure 10) plus "sweeten-off" backwash of resin in Figure 10 ; second feed is "NaOH-off" backwash from anion resin $\mathrm{SM}-73$

24 Hygroscopy - weight gain (\%) versus time in tropical room

25 Hygroscopy - weight gain (\%) versus time in prairie room

26 Flux versus time $-100,000$ MW ultrafiltration in fresh juice serum

27 NTSS (\%) versus time - 100,000 MW ultrafiltration of fresh juice serum

28 Pressure drop versus time - 100,000 MW ultrafiltration of fresh juice serum 
$x i \mathrm{i}$

LIST OF TABLES

No.

Page

1 Ultrafiltration Membrane Specifications

7

2 Separation Methods 16

3 Characterization of Puree and $\begin{array}{ll}\text { Separated Fractions } & 17\end{array}$

4 Characterization of Puree 19

5 Characterization of Diluted Pastes 20

6 Results of Static Mixer Recombination with Three Separation Techniques

7 Results of stomacher Recombination with Two Separation Techniques

8 Results of Homogenizer Recombination with Three Separation Techniques

9 Consistency Measurements and Chemical Analyses of Homogenized Tomato Puree Samples

10 Change in Viscosity will 3tomaching 2 Minutes and Sitting

11 Characterization of Puree and Rinsed and Concentrated Fractions

12 Original and Recombined Purees 43

13 Original and Recombined Purees after Different Homogenization Times

14 Original and Recombined Purees before and after Refrigerated storage

$15 \mathrm{pH}$ of Tomato Juice and Serum Harvested at Six stages of Maturity

16 Tomato Juice Hunter Color Readings of Tomatoes Harvested at Six stages of Maturity 


\section{xiii \\ LIST OF TABLES (CON'T.)}

No.

$\underline{\text { Page }}$

17 Percent Total Solids in Tomato Juice

Adjusted to $5.5 \mathrm{Brix}$ from Tomatoes

Harvested at various stages of Maturity 52

18 Characterization of Puree and Fractions . 54

$19100,000 \mathrm{MW}$ Ultrafiltration Testing with Rinse/serum

20100,000 MW Ultrafiltration Temperature

Scans with Rinse/serum

212000 MW Ultrafiltration Testing with

Low/Int. MW Fraction

22 Acidity of Effluents from Cation Exchange with IWT C-391b of Organic Acid Salts Samples 73

23 Mass Balance 76

24 Results of Recombinations 78

25 Pulp Drying Results . 81

26 Characterization of Fresh Juice and Fractions 86

27 Characterization of Fresh Juice and Recombined Samples.

88

$28100,000 \mathrm{MW}$ Ultrafiltration Testing with

Fresh Juice Serum

29100,000 MW Ultrafiltration Temperature Scans with Fresh Juice Serum 
$x i v$

\section{ACKNOWLEDGEMENTS}

Work presented in this report was partially supported by the United states Department of Energy (DOE), under Contract No. DE-AC07-84ID12553.

The authors extend special thanks to Mr. William M. Sonnett, DOE-OIP (Washington, D.C.), and Mr. David M. Blanchfield, DOE-ID (Traho Falls, ID). Gratitude is also extended to Mr. Stephen $A$. Leeper, E.G.\&G. Idaho, Inc. (Idaho Fal1s, 1D).

We especially wish to thank the members flum the food industry n our advisory committee who provided input, advise, enthusiasm, and recommendations for the execution of the project.

We also wish to thank Contadina Foods, Inc. (Woodland, CA) and Tri/Valley Growers (Modesto, CA) for tomato puree, Norton Co. (worcester, MA) for technical assistance in selection of appropriate microporous filtralion equipment, centrino (Northvale, NJ) for the loan of and assistance with a westfalia Decanter centrifuge, Niro Atomizer (Hudson, WI) for the loan uf and advice on use of ultrafiltration equipment, Illinois water Treatment Co. (Rockford, IL), for advise and samples of ion exchange resins, and H.B. Fuller Co., Monarch Div. (Minneapolis, MN) for the use of their membrane cleaners. In addition, we acknowledge the assistance of Steve A. Rittmanic, Joyce C. Hung, and Bradford $H$. Allen for analytical testing. 


\section{INTRODUCTION}

In 1970 the food processing industry used approximately 3.3 quads of energy for all aspects of food processing, including energy for processing the food, manufacturing paper, glass and metal containers, transporting food products, and manufacturing processing machinery and trucks and trailers for transportation. of this total, 1.5 quads were used for manufacturing metal containers and for transporting food products (Loftness, 1978). Transportation and containerization are major costs associated with food processing.

In juice processing, for example, products are concentrated by evaporation prior to packaging and shipping to reduce containerization and trasportation costs. The water content is reduced significantly. However, a significant amount of water remains in the concentrated product. For example, when tomato juice ( $\sim 5 \%$ total solids) is conventionally concentrated to paste of $30 \%-$ $40 \%$ total solids, it still contains $60 \%-70 \%$ water. Approximately 500,000 tons of conventionally concentrated tomato paste are produced in the United states each year, thus requiring transportation of 300,000 to 350,000 tons of water.

As tomato juice is concentrated by evaporation, the viscosity increases, thus limiting the amount of water which can be removed by evaporation. Refinements of the evaporation technology can only produce minor increases in achievable concentration.

In this project, a new approach is being studied (Fig. 1). In these studies, tomato juice was separated into pulp and serum fractions. This concept allows the individual fractions to be processed more efficiently. The pulp was rinsed to remove water soluble materials such as sugars and acids. These components may adversely affect the quality of the dried pulp. The rinse watcr 
was added to the serum to produce a rinse/serum fraction. The resulting rinse/serum fraction was treated by UF to produce a high-molecular weight (MW) fraction and a low/intermediate-MW fraction. The permeate, or low/intermediate-Mw fraction was ultrafiltered to produce a low-MW and an intermediate-MW fraction. These resulting fractions were concentrated by vacuum evaporation to further reduce water content. This separation, fractionation, and concentration process can provide substantial economic benefits by redueing the amount of water to be containerized and transported with the essential product. I'hree recombination techniques were studied: homogenization, stomacher blending, and static (in-line) mixing. Quality of the recombined product was analyzed in terms of viscosity, color, and syneresis. Additionally some studies were performed with fresh tomato juice instead of canned puree.

Fractionation of the rinse/serum fraction could allow concentration of individual components so that transportation of only "essential" ingredients is necessary. If practical, the sugars and/or organic acids will not be transported, and recombination may use locally available watcr, sugar, and organic acids.

The proposed approach may be applicable to the processing of tomato, orange, apple, and grape juices. Significant energy savings could result in several segments of the juice processing industry.

The nverall objective of this project is the development of energy efficient separation, fractionation, and concentration processes for food products in order to reduce processing, preservation, and transportation energy requirements and their associated costs. 


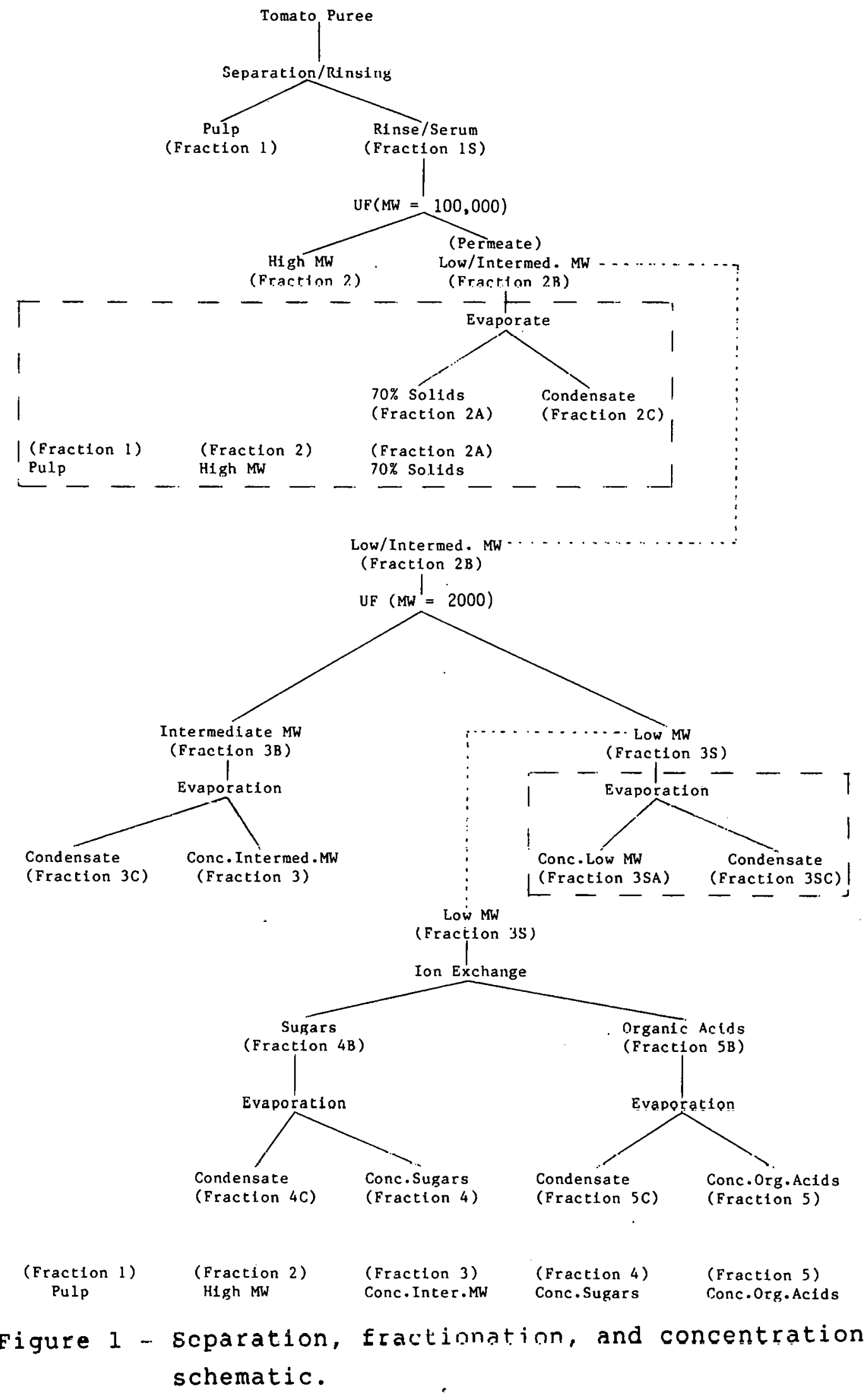


TESTING AND RESULTS

EQUI PMENT

The following equipment was used for Phase I separation studies:

Centrifuge - Sorvall RC-5B and SS-3 centrifuges with GSA rotors used for separation by density. These centrifuge heads, when operated at $12,0 \cup 0 \mathrm{rpm}$, have a g-force (relative centrifugal force) of approximately $19,000 \pm 4000 \times \mathrm{g}$ (gravity):

Conventional Filter - A conventional filter allowed separation by size. This consisted of amilk filter disc, 38 um pore size. This consisted of a milk filter disc, 38 um pore size in a Buchner funnel. Vacuum was used to drive the separation.

Microporous Filter - A ceramic microfilter (Norton Co.) also separated by size. Modules with 1.0 um and 0.2 um pore sizes were used. Each module $(2.5 \mathrm{~cm} \times 40 \mathrm{~cm})$ contained eight ceramic tubes $(2.8 \mathrm{~mm}$ ID) in a shell and tube configuration. The total surface area was $0.3 \mathrm{ft}^{2}$ per module.

Three different pumping units were used with the microporous filtcr: a Rannie A3 piston pump, a poilable pumping unit (CARRE, INC.) with a centrifugal booster pump and a $3 \mathrm{hp}$ high pressure diaphragm pump, a lab top pumping unit (Norton Co.) employing an external gear pump (Indiana General).

Two modes of operation were used. Recirculation mode (Fig. 2) is run with permeate and concentrate returning to the feed tank. Batch mode (Fig. 3) is run to effect concentration, with concentrate returning to the feed tank and permeate going to a permeate holding tank. 


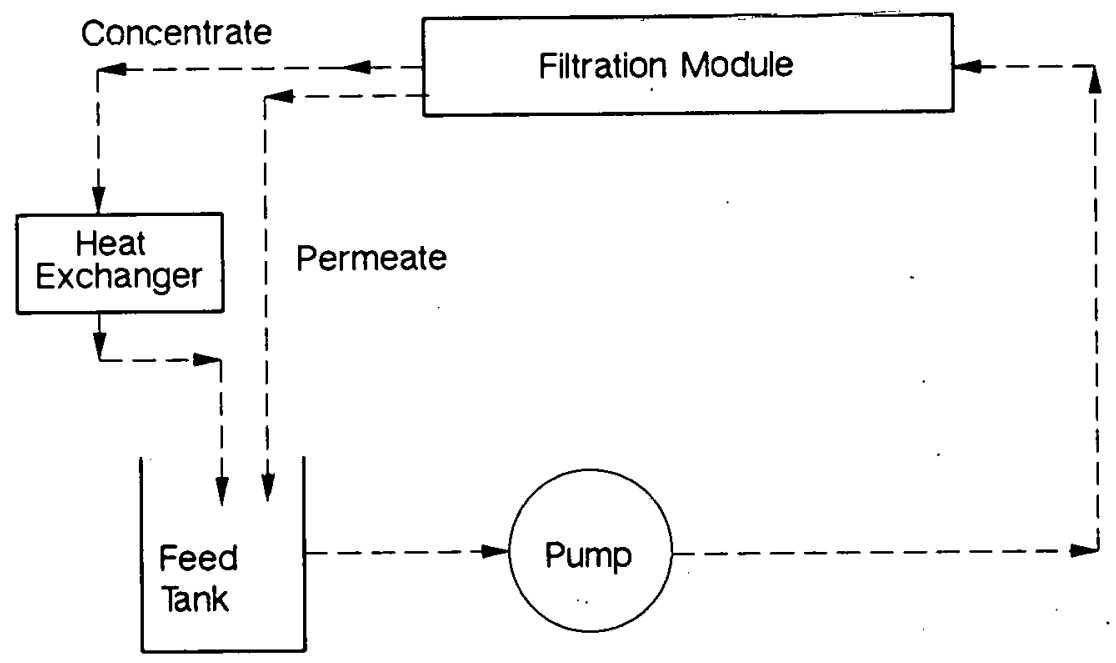

Figure 2 - Recirculation mode operation.

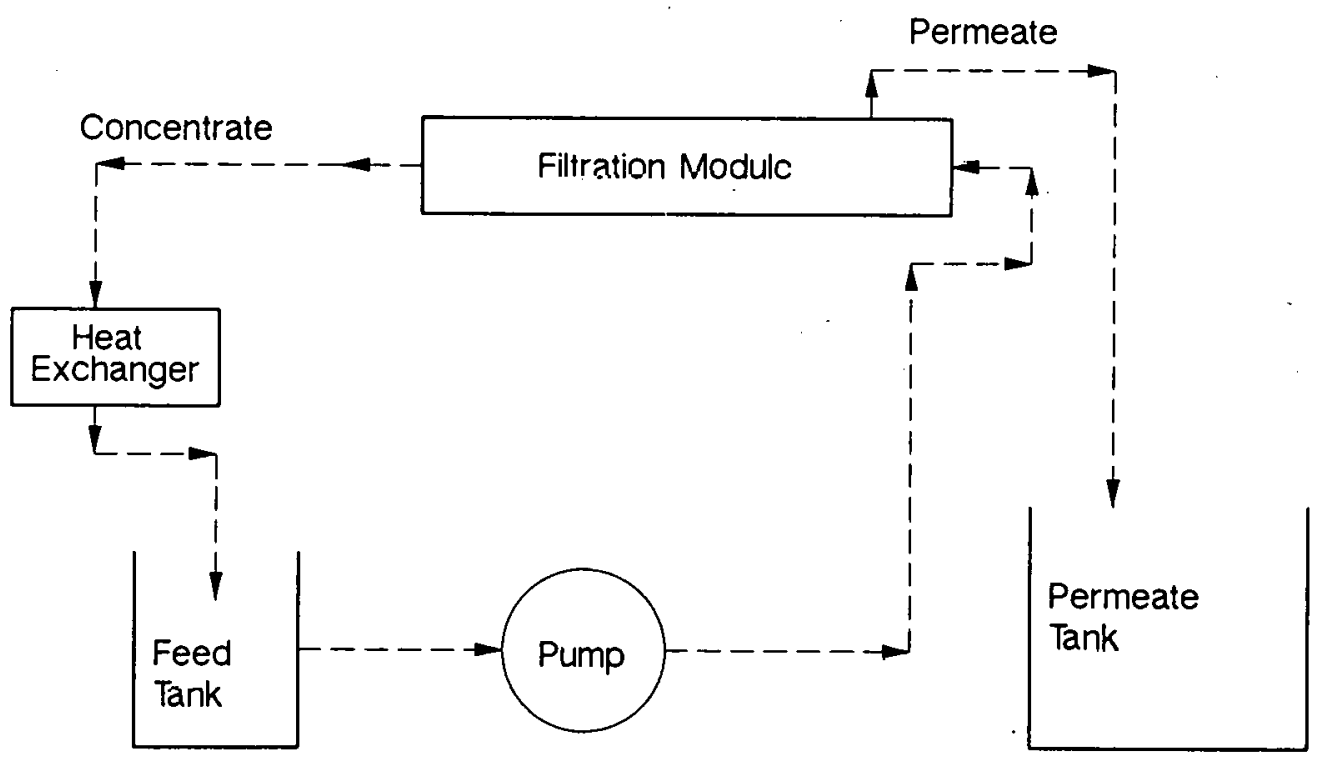

Figure 3 - Batch mode operation. 
The following equipment was used for Phase II separation and fractionation studies:

Decanter Centrifuge - A Westfalia Model CA 220-110 Decanter was used for separating tomato puree. This centrifuge has a maximum g-force of $\sim 3500$.

Ultrafilter - A DDS/Niro Lab 20 Module with Rannie A3 piston pump was ucod. This is a plate and frame type module. Membranes used include:

2000-MW-cutoff value, Type GR90PP (polysulfone)

100,000-MW-cutoff value, Types GR40PP and PES-100

(polysulfone; polyether sulfone) (see Table 1 for specifications.)

Each membrane had $0.195 \mathrm{ft}^{2}\left(0.018 \mathrm{~m}^{2}\right)$ surface area.

Four modes of operation were used:

Recirculation mode and batch luvde wcrc run as tescribed in the Microporous Filter section.

Batch diafiltration mode is used after batch mode has been used to produce a concentrate. Water is added to the concentrate in the feed tank and the UF unit is then run in batch mode. 
TABLE 1. ULTRAFILTFATION MEMBRANE SPECIFICATIONS

\begin{tabular}{|c|c|c|c|c|c|c|c|}
\hline \multirow{3}{*}{$\begin{array}{l}\text { Meniorane } \\
\text { Type }\end{array}$} & \multirow{3}{*}{$\begin{array}{l}\text { Component } \\
\text { Type }\end{array}$} & \multirow{3}{*}{$\begin{array}{l}\text { Approx. } \\
\text { MW-Cutoff } \\
\text { Value }\end{array}$} & \multirow[b]{3}{*}{$\mathrm{pH}$} & \multicolumn{4}{|c|}{ Recommended Operation Limits } \\
\hline & & & & \multicolumn{2}{|c|}{ Temperature } & \multicolumn{2}{|c|}{ Pressure } \\
\hline & & & & ${ }^{\circ} \mathrm{C}$ & ${ }^{\circ} \mathrm{F}$ & $\underline{\mathrm{MPa}}$ & psi \\
\hline GRAJPP & Polysulfone & 100,000 & $1-13$ & $0-75$ & $32-167$ & $0-1$ & $0-145$ \\
\hline PES100 & Polyethersulfone & 100,000 & NA & $0-75$ & $32-167$ & $0-0.7$ & $0-100$ \\
\hline 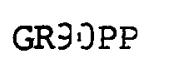 & Polysulfone & 2000 & $1-13$ & $0-75$ & $32-167$ & $0-2$ & $0-290$ \\
\hline
\end{tabular}


Batch diafiltration mode is used to wash low-molecular weight solutes out of the concentrate. The fraction of low-MW solutes removed is directly proportional to the amount they are diluted by the volume of water added to the feed tank.

Continuous mode (or feed and bleed) was run initially in batch mode to increase the concentration of the retentate lu lie level whele lle peilieale 33 (soluble solids) equalled the original feed ss. Then batch mode operation was continued, but with feed added periodically to the feed tank in amounts equal to the volume lost to permeate (Fig. 4). This was done to increase the amount of constituents passing through the membrane without diluting the permeate.

In some cases a temperature scan was made while in batch mode. During this test, the pressure and flow rates are held constant while the temperature is varied; flux and rejection data are monitored at various temperature settings.

Ion Exchange - Anion exchange resins, IWT SM-73 and IWT A-399b (Illinois water Treatment Co.), were used for removing organic acids from sugars. The columns used were $2.3 \times 27 \mathrm{~cm}$ and $1.9 \times 35 \mathrm{~cm}$ respectively.

Cation exchange resin, IWT $\mathrm{C}-391 \mathrm{~b}$ was used to convert organic acid salts to organic acids. The column used was $1.9 \times 35 \mathrm{~cm}$. 


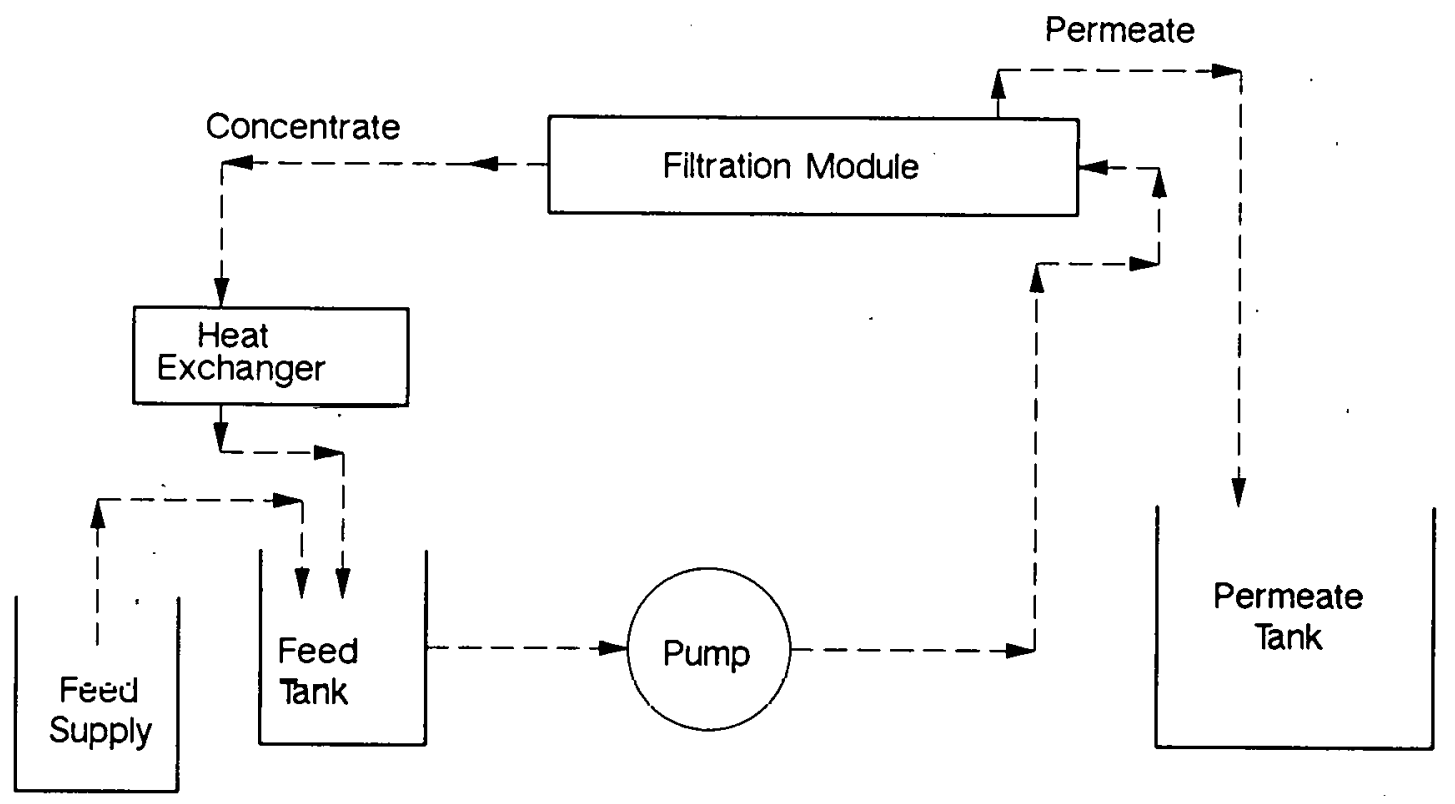

Figure 4 - Continuous mode operation. 
The following equipment was used for serum concentration:

Hyperfilter - A spiral wound thin film composite membrane (FT30 ) was examined for use in concentrating tomato serum. Each spiral wound module $(6.4 \mathrm{~cm}$ diameter $x 36 \mathrm{~cm}$ length) container $0.52 \mathrm{~m}^{2}$ membrane area. Two modules were used per pressure vessel. Pumping was accomplished by means of the portable pumping unit described in the Microporous Filter section. (Tomato serum for testing with the liypeililter was produced by means of a tubular zoss [zirconium oxide stainless steel] ultrafilter [CARRE, Inc.] and two small pilot scale centrifuges [Alfa-Laval] [2000 and $18,000 \mathrm{rpm}]$.

Rotary evaporator - A Yamato Rotary Evaporator (Model No. RE-51B) and a Buchi/Brinkmann Rotovapor-R were used in connection with vacuum.

Pilot scale evaporator - A single effect Junior Plate Evaporator (APV) was used at $\sim 160^{\circ} \mathrm{F}\left(70^{\circ} \mathrm{C}\right)$.

The following equipment was used for recombination of fractions:

Homogenizer - A Brinkmann Homogenizer PT-35 (also known as Polytron) with a $\mathrm{PT}-35 / \mathrm{K}$ probe generator which runs at 0-20,000 rpm was used. The homogentzer cumbines ultrasonic energy with mechanical shearing.

Static Mixer - A static mixer (Komax systems, Inc.) was used. This inline mixer $(1.2 \mathrm{~cm} \times 28 \mathrm{~cm})$ uses multivaned elements to divide and recombine a flowing process stream. Product flow was driven by a peristaltic pump (Sigmamotor T6S) at 0.5 gpm. 
Stomacher - A Stomacher 80 laboratory blender (Dynatech Labs., Inc.) provided mixing by action of two reciprocating paddles on a whirl-pak bag. This instrument is commonly used for mixing in the laboratory.

\section{ANALYTICAL PROCEDURES}

1. Natural tomato soluble solids (NTSS) - Samples were analyzed with a Bausch and Lomb 33-45-58 refractometer (Lamb, 1969). For some testing the term ${ }^{\circ}$ Brix is used interchangeably with $\%$ NTSS, since Brix is read on the sugar scale (\% sucrose) on a refractometer; $\%$ NTSS is also read as : sucrose on the sugar scale on a refractometer. Some samples were analyzed using an AO Hand Refractometer Model 10430.

2. Gross viscosity - The Bostwick procedure was used (NCA, 1968). In this test a low centimeter $(\mathrm{cm})$ value indicates a high viscosity value.

3. Total solids (TS) - Total solids were determined by drying at $70^{\circ} \mathrm{C}$ under vacuum for 4 hours (NCA, 1968). Samples were also analyzed using a microwave drying moisture solids analyzer (CEM Corp.) following the method of Chin et al. (1985).

4. Filtered Total Solids (FTS) - Samples were centrifuged at $10,000 \mathrm{rpm}$ for $20 \mathrm{~min}$. Supernatant was filtered with a Gelman Type A-E glass fiber filter. The filtrate was analyzed for total solids by the vacuum oven method. 
5. Soluble Solids (SS) - The soluble solids was calculated from the total solids and filtered total solids determined by the vacuum oven method:

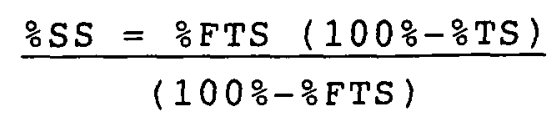

This equation is derived trom the fullowing thrce equations:

$$
\begin{aligned}
& \because \mathrm{FIS}=\frac{\text { s.SS }}{\because \mathrm{SS}+\% \mathrm{H}_{2} \mathrm{O}} \\
& \because T S=\frac{\% S S+\% I S}{\% S S+\% I S+\% \mathrm{H}_{2} \mathrm{O}} \\
& 100 \%=\% \mathrm{SS}+\% \mathrm{IS}+\frac{\%}{2} \mathrm{O}
\end{aligned}
$$

6. Syneresis (Serum Separation) - Sample ( $40 \mathrm{gm}$ ) was weighed into a tube $(26 \mathrm{~mm}$ i.d.) with a 60 mesh screen on the bottom. The tube was suspended over a $50 \mathrm{~m}$ ? beaker. At time intervals $(0.25,0.5,1,2,3,4,5$ hrs) fluid that had accumulated in the beaker was weighed. value lepurted is the weight of fluid at $1 \mathrm{hr}$ divided by $40 \mathrm{gms} \times 100$. This method was adapted from the method of N. Stoforos (University of California, Davis).

7. Color - A Minolta Chroma Meter CR-100 was used. A beaker (150ml) was filled to the rim with sample. The meter's measuring head was equipped with the glass light projection tube and was immersed $\sim 1 \mathrm{~cm}$ into the sample. Measurement $\left(L^{*} a * b *\right)$ was made. (The instrument makes three measurements and records the mean 
value.) The measuring head was removed from the sample, cleaned, and dried. The measurement process was performed a total of 10 times, and the overall mean was reported.

8. Titratable Acidity - The electrometric titration method, using $0.02 \mathrm{~N}$ and $0.1 \mathrm{~N} \mathrm{NaOH}$ to $\mathrm{pH} 8.1$, was used (NCA, 1968). The results were presented as the anhydrous citric acid equivalent.

9. $\mathrm{pH}-\mathrm{pH}$ meters (IBC TropHy Meter and Yokogawa Model PH51 Pocket pH Meter) were used.

10. Conductivity - A conductivity meter (Yokogawa Model sc51 Pocket Conductivity Meter) was used.

11. Sugars - A Bio-Rad high performance liquid chromatographic (HPLC) system with column heater and refractive index detector was used. An HPX-87C column (Bio-Rad) was used with the HPLC system. Samples were diluted 1:10, mixed thoroughly, centrifuged, and the supernatant filtered through a 0.45 micron filter.

12. Organic Acids - (See Sugars procedure for instrument used.) An HPX-87H column (Bio-Rad) was used. Samples were treated as for sugar analysis, but with an additional clean-up step: an aliquot was passed through a Bond-Elut PSA column, rinsed with methanol and with water, and then eluted with $2 \mathrm{~N} \mathrm{HCl}$.

13. Pectin - Samples were analyzed in the following manner. Sugars were removed and the samples defatted as per Southgate (1969). Pectin was extracted by pectinase following McCready and McComb (1952). The uronic aids 
were determined colorimetrically using the method of Blumenkrantz and Asboe-Hansen (1973).

14. Protein - Samples were analyzed using the Kjeldahl method $2.055-2.057$ (AOAC, 1984).

15. Lipid - Samples were analyzed using the ChloroformMethanol Extraction method 43.276-43.277 (AOAC, 1984).

16. Molecular Weight Distribution of pectins and rruleins (See sugars procedure for instrument used.) TSK-40 and TSK-60 columns (Bio-Rad) were used. Samples of pectin extract or tomato fractions were diluted in mobile phase to yield about $0.1 \%$ as pectin. Mobile phase was acetic acid-sodium sulfate ( $\sim \mathrm{pH} 4)$ to neutralize acid groups on pectins to negate ionic interactions on the column so separation would be by size only.

\section{PROCEDURES AND RESULTS}

\section{Phase I}

Studies were performed with commercially-prepared tomato puree (8-14\% NTSS) because of its availability year-round, and because its viscosity can be easily measured by the Bostwick procedure which is commonly used in the tomato processing industry.

\section{Separation and Recombination studies}

Tomato puree ( $10 \%$ NTSS) was separated into two fractions (pulp and serum) by three methods:

\section{centrifugation}

conventional vacuum filtration

crossflow microporous filtration (or microfiltration) 
Each of the resulting fractions, plus the original puree, were then characterized as described in the analytical procedures section.

Additional separation studies examined in a greater detail the microfiltration separation technique.

Recombined tomato puree was then prepared from the fractions produced by the three separation techniques utilizing three recombination methods:

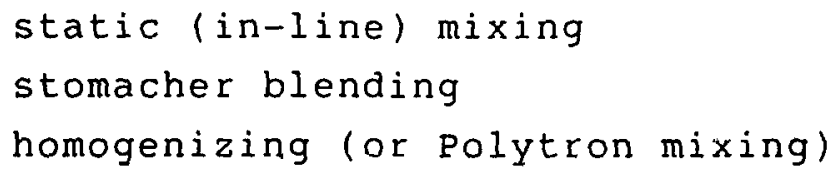

Additional recombination studies examined the effect of the stomacher and homogenizer on the puree without prior separation.

In addition some studies examined the effect of microfiltration and homogenization upon tomato puree cells.

Separation and Characterization. Table 2 gives a brief comparison of the three methods used and the separation obtained. Table 3 gives results of the characterization of the original purees and the fractions obtained upon separation. Fig. 5 shows the HPLC output for organic acids of three samples and a standard. In addition the sub-contractor performed characterization studies on tomato puree (Tablc 4) and diluted tomato pastes (Table 5). The three separation methods are described in more detail following the tables. 
TABLE 2. SEPARATION METHODS

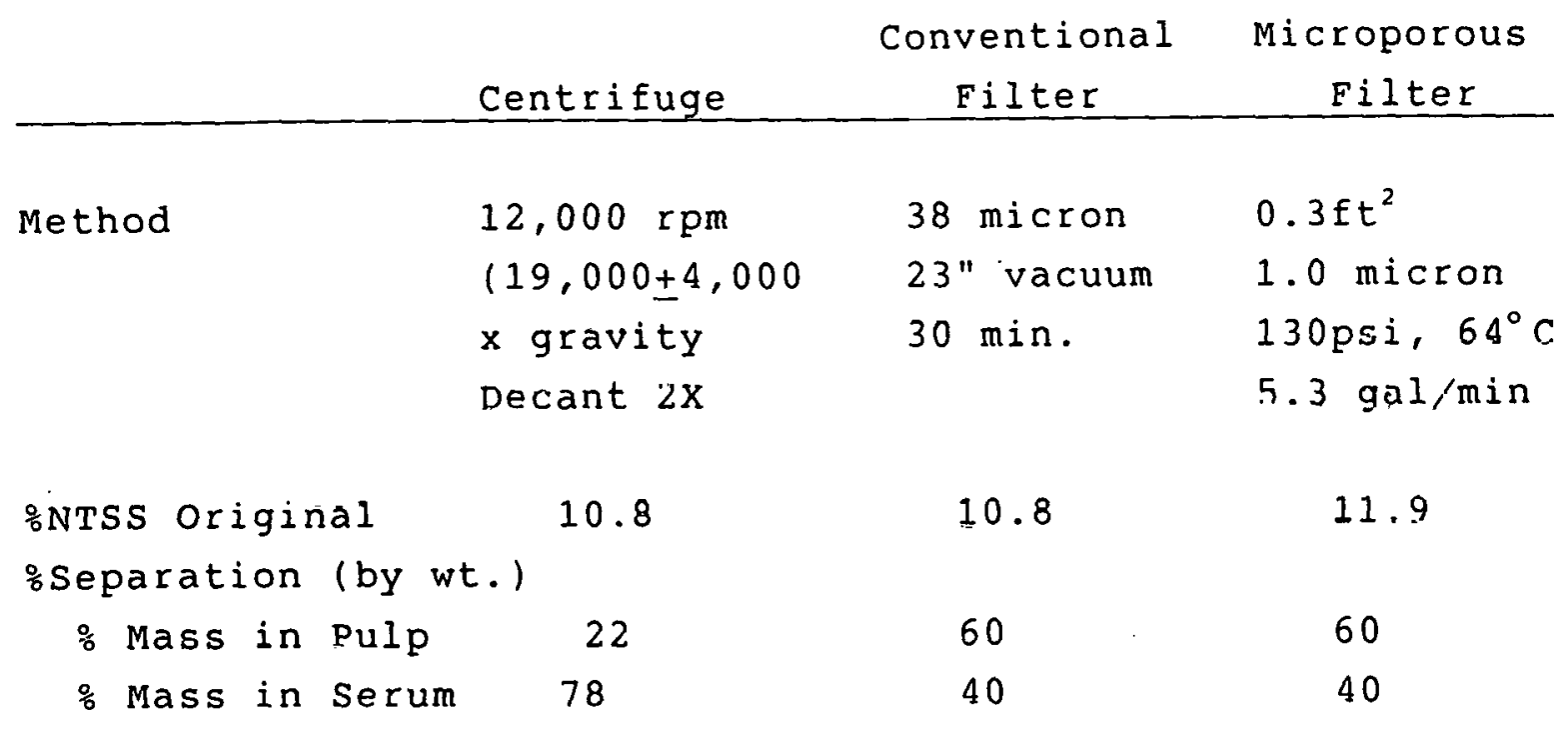


TABLE 3. CHARACTERIZATION OF PUREE AND SEPAZATED FRACTIONS

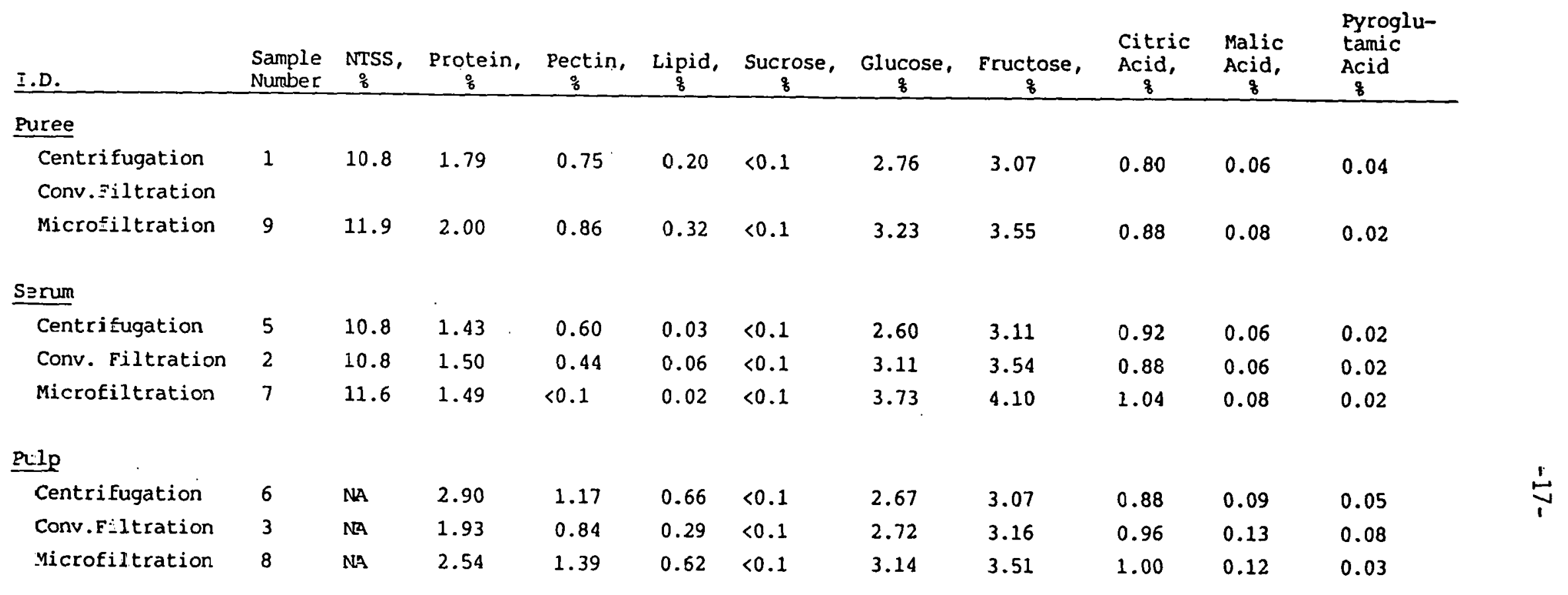



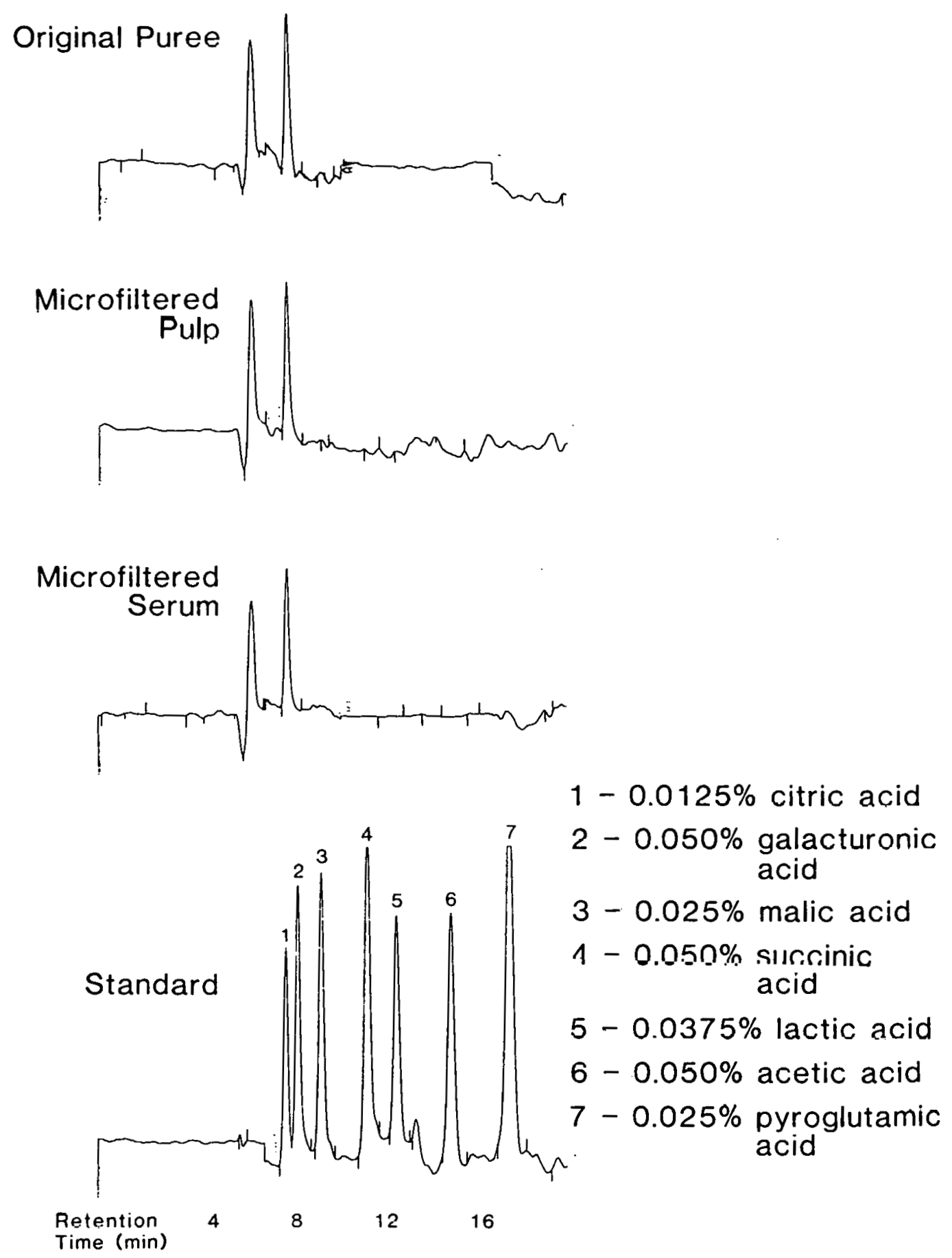

Figure 5 - High performance liquid chromatogram of organic acids for three samples and a standard. The samples: original puree, microfiltered pulp, and microfiltered serum contained respectively: $0.91,0.94$, and $0.86 \%$ citric acid. 
TABLE 4. CHARACTERIZATION OF PUFEE

\section{Juice Concentrate}

Bostwick Consistency $(\mathrm{cm})$

Brix $\left({ }^{\circ}\right)$

Libby's Efflux Viscosity (catsup opering) (sec)

Precipitate wt ratio( $\%)$

To:al solids $(\%)$

Ash

Hunter Color

L
a
b

Titratable Acicity(ml)

$\mathrm{pH}$

To:al Carbohydrate $(\mathrm{mg} / \mathrm{ml})$

Serum

Osiwald Serum viscosity(sec)

Insoluble Solids

Cell Wall Fractionation (gm/lgm solids)

Ionically ass. pectin

Covalently bound pectin

Hemicellulose

Cellulose

$\%$ Recovery

${ }^{*} s$ = standard deviation

\begin{tabular}{|c|c|c|c|c|}
\hline Trial 1 & Trial 2 & Trial 3 & $x$ & $\mathrm{~s}^{*}$ \\
\hline $\begin{array}{r}5.3 \\
13.0 \\
719\end{array}$ & $\begin{array}{r}5.7 \\
13.1 \\
650\end{array}$ & $\begin{array}{r}5.5 \\
13.3 \\
646\end{array}$ & $\begin{array}{r}5.5 \\
13.1 \\
672\end{array}$ & $\begin{array}{c}0.2 \\
0.15 \\
41\end{array}$ \\
\hline $\begin{array}{r}36.75 \\
14.16 \\
1.07\end{array}$ & $\begin{array}{r}35.80 \\
14.05 \\
1.20\end{array}$ & $\begin{array}{r}36.24 \\
14.08 \\
1.27\end{array}$ & $\begin{array}{r}36.26 \\
14.10 \\
1.18\end{array}$ & $\begin{array}{l}0.48 \\
0.06 \\
0.10\end{array}$ \\
\hline $\begin{array}{r}25.5 \\
26.9 \\
13.1 \\
11.4 \\
4.3 \\
52\end{array}$ & $\begin{array}{c}25.7 \\
26.7 \\
13.1 \\
11.3 \\
4.4 \\
68\end{array}$ & $\begin{array}{c}25.5 \\
26.8 \\
13.0 \\
11.5 \\
4.4 \\
\mathrm{NA}\end{array}$ & $\begin{array}{c}25.5 \\
26.3 \\
13.1 \\
11.7 \\
4.7 \\
60\end{array}$ & $\begin{array}{c}0.12 \\
0.1 \\
0.06 \\
0.1 \\
0.06 \\
11\end{array}$ \\
\hline
\end{tabular}

94.7

0.1732

0.1413

0.1786

0.4984

$99.15 \%$ 
TABLE 5. CHARACTERIZATION OF DILUTED PASTES

(Same variety, harvest day, and identical treatment except hot vs. cold break; diluted to $12.1^{\circ}$ Brix before analysis; reported values are averages for at least triplicate determination.)

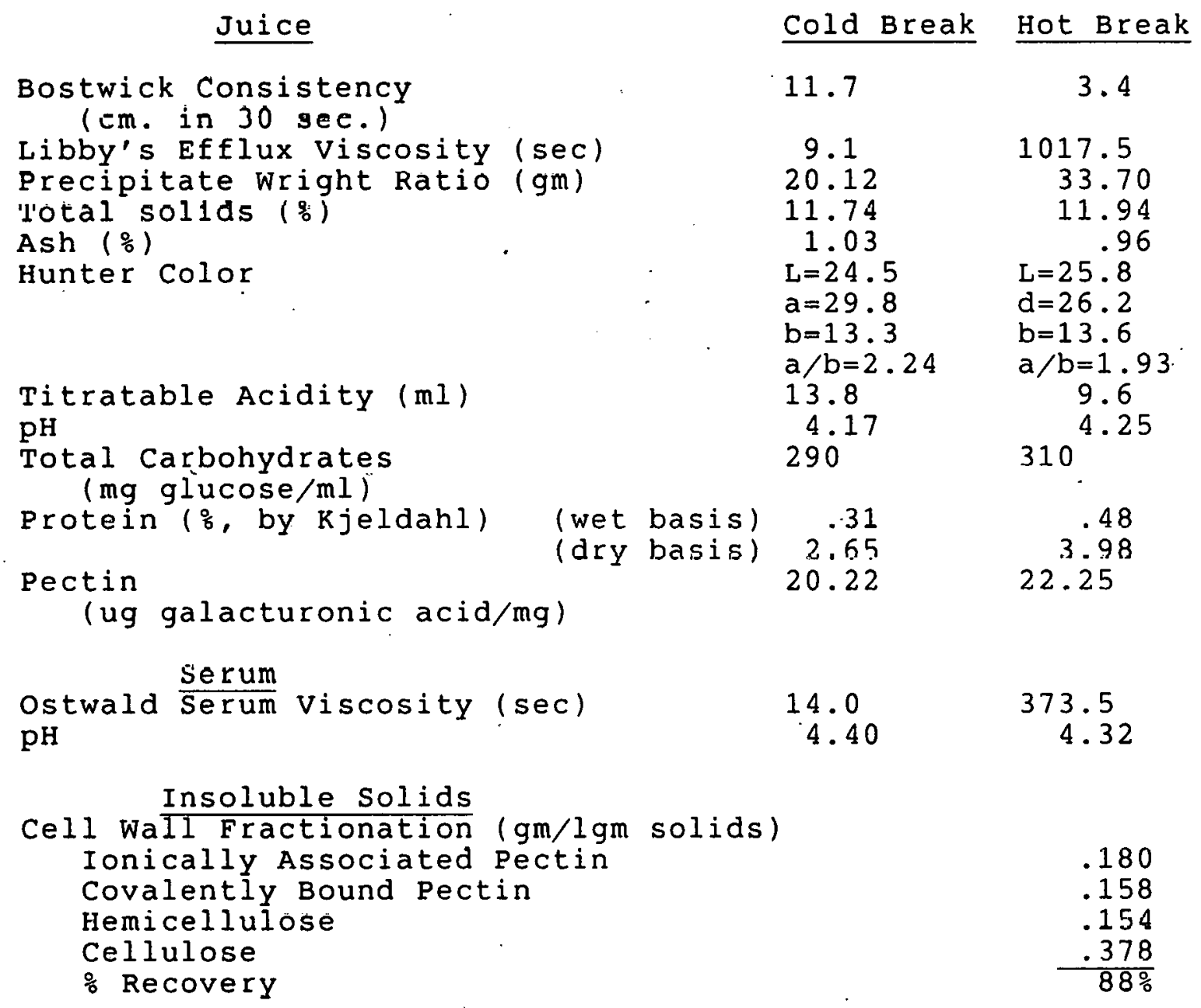


Centrifugation

Materials:

Tomato puree - 2 cans (425 gms (a) (10.8\% NTSS)

Laboratory centrifuge and cups

Method:

1) Place puree in centrifuge cups (150 gms/cup).

2) Centrifuge at $12,000 \mathrm{rpm}, 30 \mathrm{~min}(19,000 \pm 4000 \mathrm{x}$ gravity).

3) Decant clear serum for characterization. Decant semi-clear serum into other centrifuge cups. Place pulp in container for characterization.

4) Repeat Steps 2 and 3 twice; on final decanting, all liquid goes to serum container.

Conventional filtration

Materials:

Tomato puree - 4 cans (425 gms @) (1.0.8\% NTSS)

Buchner funnels - $186 \mathrm{~mm}$ and $155 \mathrm{~mm} \mathrm{i.d.}$

Vacuum filtration manifold

Milk filter discs to fit Buchner funnels:

( 38 micron pore size)

Method:

1) Filter $1 / 10$ volume of puree (composited) in each funnel for $30 \mathrm{~min}$. Repeat until.all puree is filtered.

2) Adjust NTSS of filtrate to level of original puree with water (to make up for evaporation). 
Microporous filtration

Materials:

Tomato puree $(11,000 \mathrm{gms})(11.9 \%$ NTSS $)$

1 micron microfilter (Norton)

portable pumping unit (CARRE)

Method:

1) Heat puree to $60^{\circ} \mathrm{C}$.

2) Run puree through microfilter pumping unit in batch (concentration) mode with permeate leaving the system, concentrate returning to the feed tank. Operating conditions: $130 \mathrm{psi}$ ( 9 bar), $147^{\circ} \mathrm{F}\left(64^{\circ} \mathrm{C}\right), 5.3 \mathrm{gal} / \mathrm{min}(20 \mathrm{~J} / \mathrm{min})$. Length of test was $1.9 \cdot \mathrm{hr}$. (The flux obtained during this test was 52-48 $\mathrm{gal} / \mathrm{ft}^{2}$ day $\left(88-81 \mathrm{~L} / \mathrm{m}^{2} \mathrm{hr}\right)$ ).

3) Water was not added to the serum to make up for the small amount of evaporation during the test.

of the three separation methods studied centrifugation provided the most complete separation on a weight basis, microporous filtration provided the second most complete separation by weight. (See Additional Microfiltration studies, below.) Micro-porous filtration provided the most complete separation of pectin (Table 2).

Additional Microfiltration studies. Flux (or permeation rate) was studied versus pump flow rate $(1.5-3 \mathrm{gal} / \mathrm{min}, 5.7-11.4$ $\mathrm{L} / \mathrm{min})$ and average operating pressure (20-140 psi, $1.4-9.7$ bar). The test was run at $73-86^{\circ} \mathrm{F}\left(23-30^{\circ} \mathrm{C}\right)$. in recirculation mode. Results are shown in Fig. 6. Increasing flow rate and pressure resulted in increasing flux rate. 


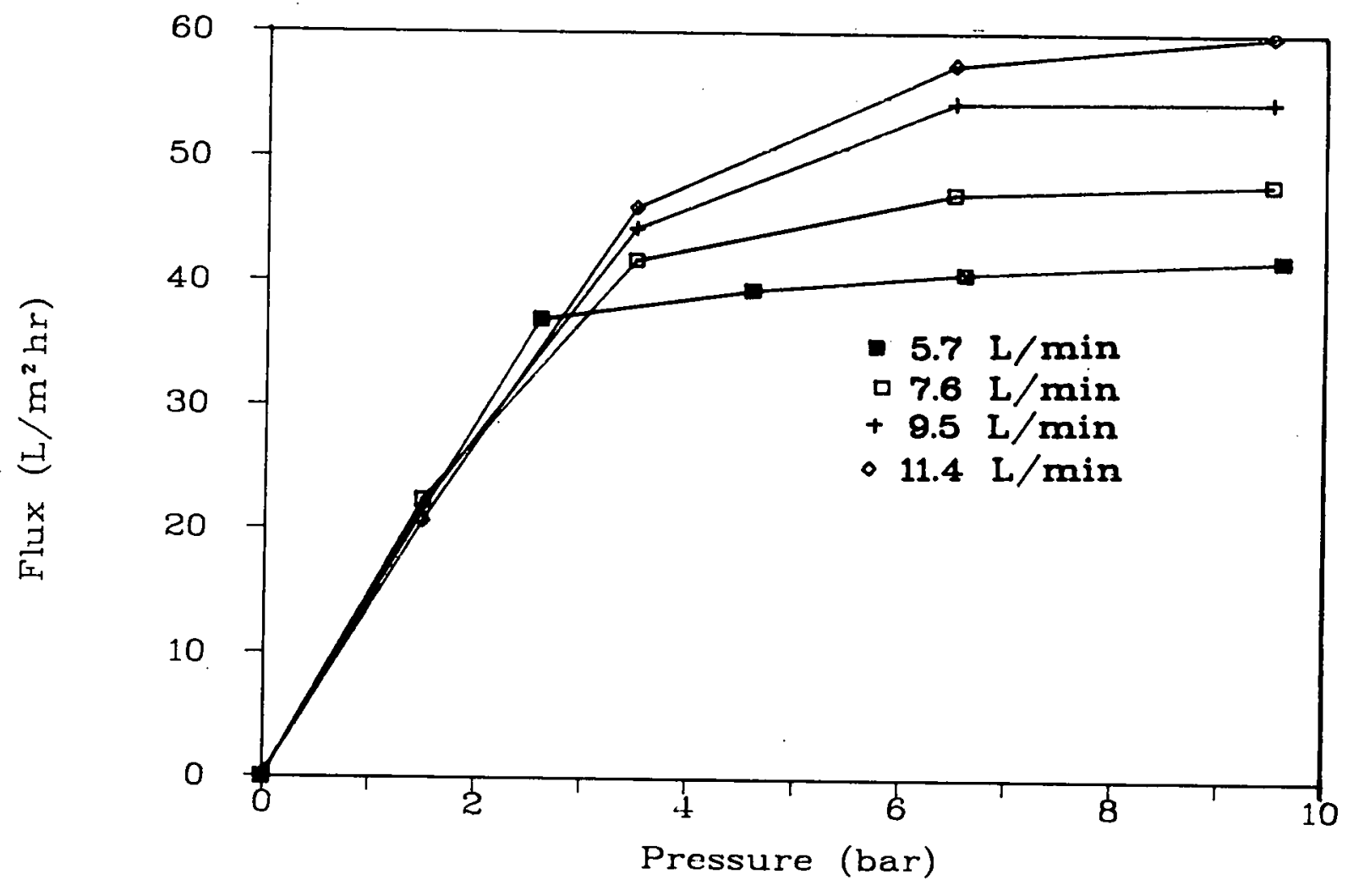

Figure 6 - Microporous filter (0.2 micron)--Flux versus pressure and flow. 
Flux was also studied versus temperature $\left(81\right.$ and $140^{\circ} \mathrm{F}, 27$ and $\left.60^{\circ} \mathrm{C}\right)$ and average pressure (20-140psi, $1.4-9.7$ bar). The test was run at $2 \mathrm{gal} / \mathrm{min}(7.6 \mathrm{~L} / \mathrm{min})$. Results are shown in $\mathrm{Fig} .7$. Increasing temperature and pressure resulted in increasing flux. 


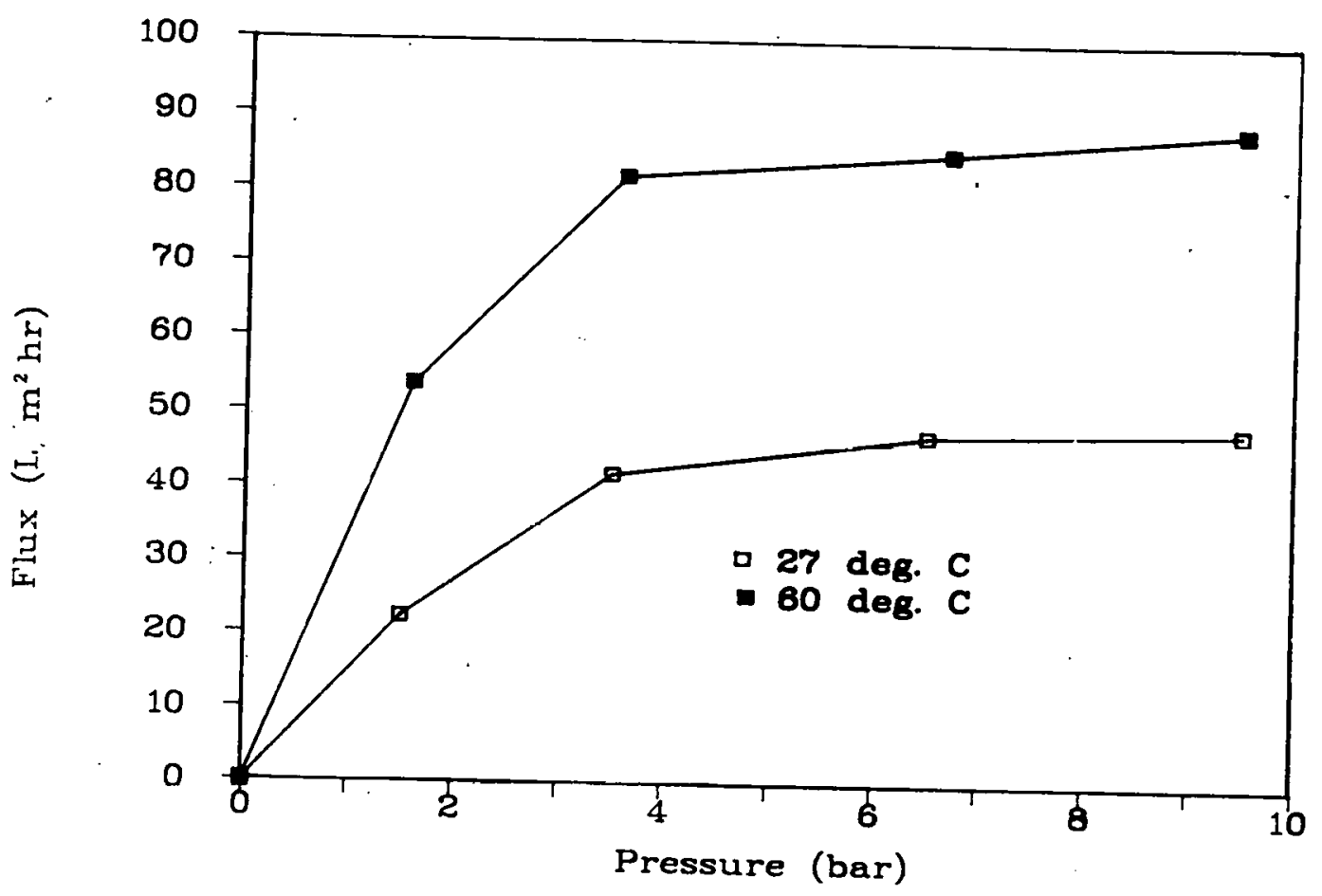

Figure 7 - Microporous filter $(0.2$ micron)--Flux versus pressure and temperature.

One test was run for $48 \mathrm{hrs}$ in recirculation mode. Operating pressure was 116 psi ( 8 bar), temperature was $111-156^{\circ} \mathrm{F}$

$\left(44-69^{\circ} \mathrm{C}\right)$, and flow rate was $\sim 5 \mathrm{gal} / \mathrm{min}(19 \mathrm{~L} / \mathrm{min})$. Initially the flux was $54 \mathrm{gal} / \mathrm{ft}^{2}$ day $\left(92 \mathrm{~L} / \mathrm{m}^{2} \mathrm{hr}\right)$. Mid-way through the test the feed was changed to fresh juice and the flux was 51 $\mathrm{gal} / \mathrm{ft} \mathrm{t}^{2}$ day $\left(87 \mathrm{~L} / \mathrm{m}^{2} \mathrm{hr}\right)$. Results are shown in Fig. 8.

Microfiltration of puree was also studied in batch mode. The inlet operating pressure was 88-120psi (6-8 bar), temperature was $115-149^{\circ} \mathrm{F}\left(46-65^{\circ} \mathrm{C}\right)$, and flow rate was $4.2 \mathrm{gal} / \mathrm{min}(16 \mathrm{~L} / \mathrm{min})$. The approximate separation by weight obtained was: $52 \%$ pulp; $48 \%$ serum. The flux varied from 54 to $83 \mathrm{gal} / \mathrm{ft}^{2}$ day $(92-141$ $\mathrm{L} / \mathrm{m}^{2} \mathrm{hr}$ ) during the $45 \mathrm{~min}$ test. 


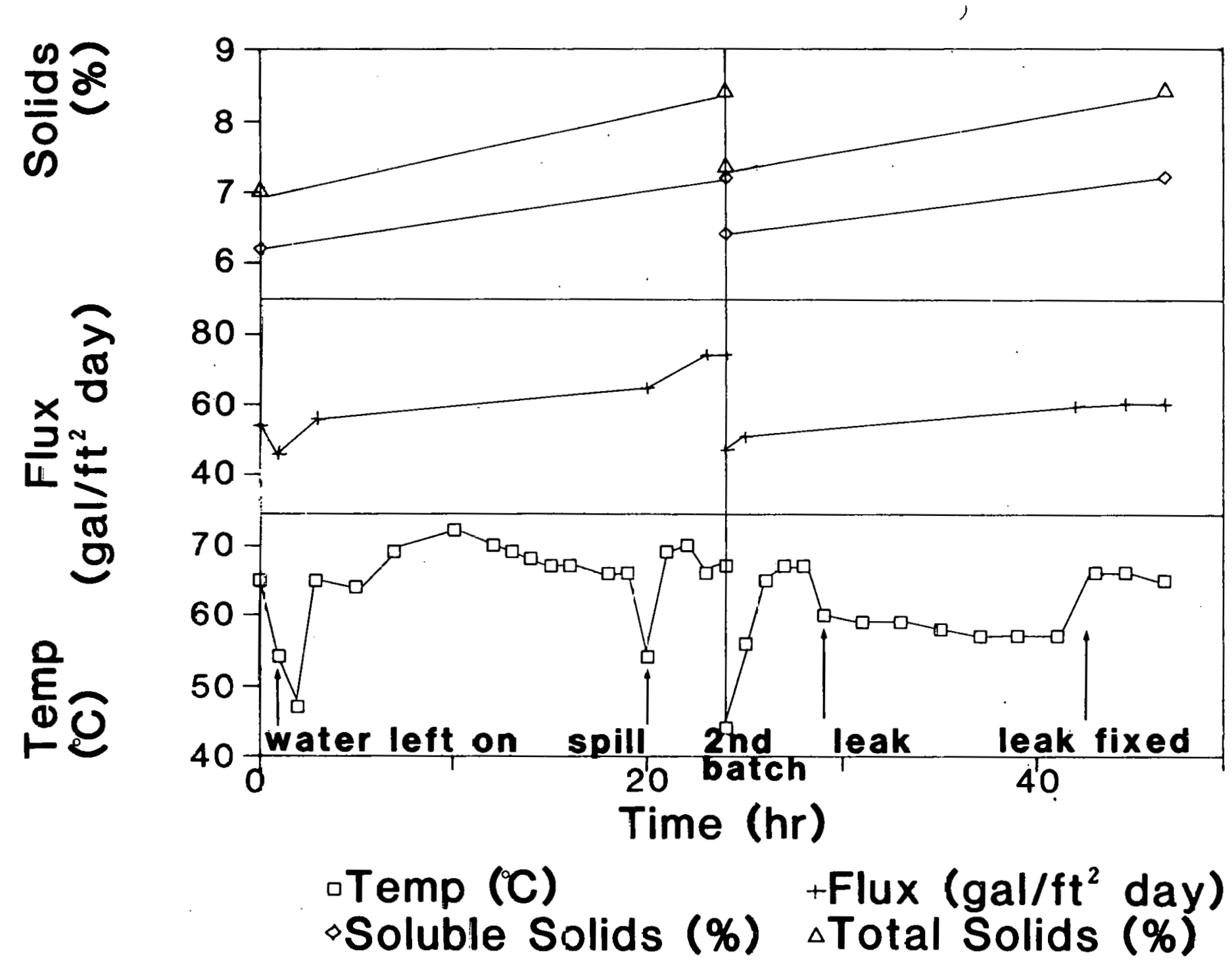

Figure 8 - Microporous filter (1.0 micron)-Flux, temperature, and $\%$ solids of permeate versus operating time. 
Recombination and Evaluation. The three recombination methods are described below, followed by the results of the recombination testing.

static Mixer.

Both fractions (serum and pulp) were placed in a feed tank and the peristaltic pump was used at $0.5 \mathrm{gal} / \mathrm{min}$ to pump the feed through the static mixer. When recombining pulp and serum separated by centrifugation, the recombined fluid passed through the static mixer three times. The fluid recombined from the fractions produced by conventional filtration and microfiltration passed through the static mixer twice in both cases.

Results of the recombinations are given in Table 6. Separation by centrifugation or conventional filtration, followed by recombination by static mixing slightly decreased viscosity $(+0.22 \mathrm{~cm}$ and $+0.18 \mathrm{~cm},+4.2 \%$ and $+3.8 \%$, respectively). Separation by microporous filtration, followed by recombination by static mixing, slightly increased viscosity $(-0.17 \mathrm{~cm},-3.2 \%)$.

Stomacher.

Both fractions (serum and pulp) were placed in whirl-pak bags and then in a protective bag and placed in the stomacher compartment. When recombining the centrifuge-separated serum and pulp, the stomacher was run for $2 \mathrm{~min}$; with the conventional filterseparated fractions, it was run and samples tested after $0.5,1$, 3 , and $5 \mathrm{~min}$. Since the conventional filter technique gave a less sharp separation than the centrifuge, recombining with the stomacher was adequate after less time. Since other testing with the stomacher (see Additional Recombination studies) showed 
viscosity deterioration with its use, this technique was not used to recombine the microporous filter-separated fractions.

Results of the recombinations are given in Table 7. After separation by centrifuge, recombination by stomacher resulted in loss in viscosity $(+1.1 \mathrm{~cm}$ to $0.6 \mathrm{~cm},+26.5 \%$ to $+10.9 \%)$; recombination by stomacher after conventional filtration resulted in no significant change in viscosity. 
TABLE 6. RESULTS OF STATIC MIXER RECOMBINATION WITH THREE SEPARATION TECHNIQUES

\begin{tabular}{ccc} 
& Conventional & Microporous \\
Centrifuge & Filter & Filter \\
\hline
\end{tabular}

$\%$ NTSS

$\begin{array}{llll}\text { Original Puree } & 9.2 & 10.8 & 9.2 \\ \text { Recombined Puree } & 9.2 & 10.8 & 9.15\end{array}$

Visccsity (Bostwick, cm.)

$\begin{array}{llll}\text { Original Puree } & 5.28 & 4.75 & 5.27 \\ \text { Recombined Puree } & 5.5 & 4.93 & 5.1\end{array}$

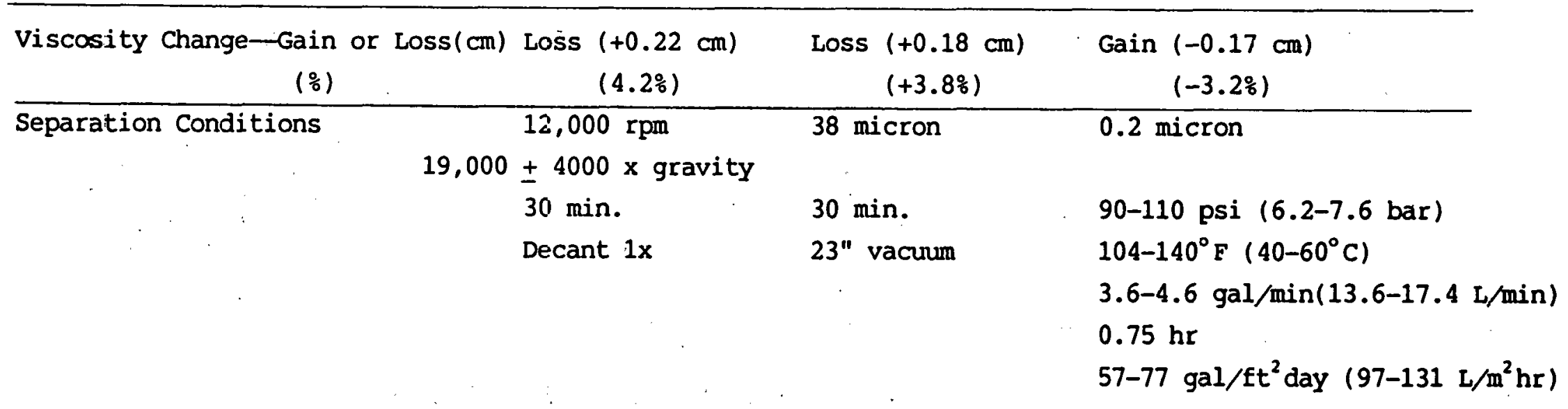


TABLE 7. RESULTS OF STOMACHER RECOMBINATION WITH TNO SEPARATION TECHNIQUES

Centrifúge

Conventional Filter

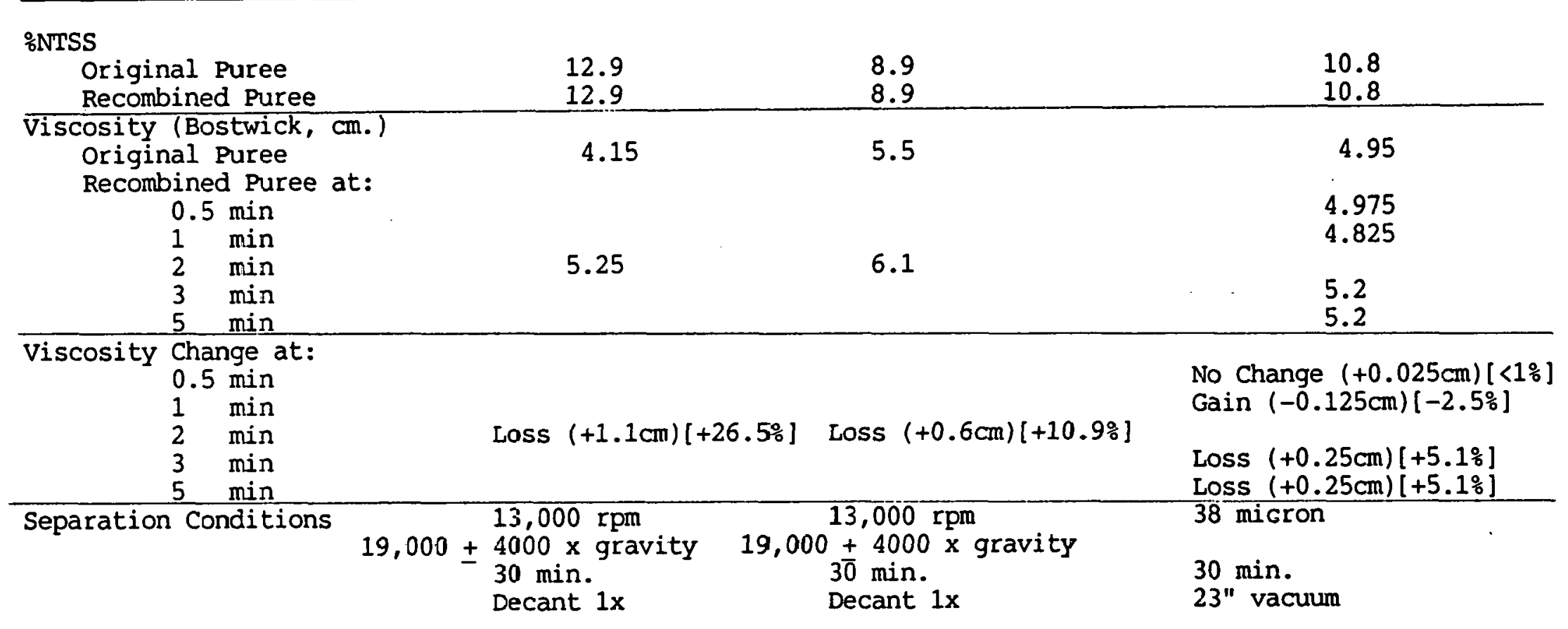


Homogenizer.

The homogenizer was used for recombining by placing serum and pulp ( $\sim 300 \mathrm{gms}$ ) into a $400 \mathrm{ml}$ beaker and homogenizing for 0.5 to 7 minutes (depending upon the test) while moving the beaker to distribute the homogenizing action throughout the beaker. In one study, the recombined puree was heated before the viscosity was measured.

Results of the recombinations are given in Table 8 . After separation by all three methods, recombination by homogenizer for 5 min or longer resulted in viscosity gain $(-0.43 \mathrm{~cm}$ to $-1.73 \mathrm{~cm}$, $-8.9 \%$ to $-33.0 \%)$; recombination by homogenizer for $3 \mathrm{~min}$ also caused a viscosity gain for all but the centrifuge separation method.

In addition the sub-contractor duplicated a centrifugation study with tomato puree adjusted to $11.6^{\circ}$ Brix. Samples of the original puree and recombined centrifuged puree were characterized (Table 9).

All data points given in Table 9 are the average of duplicate or triplicate determination. Bostwick consistency, serum viscosity and precipitate weight ratio measurements indicate an increase in viscosity due to homogenization. All chemical measurements suggested that no real changes in chemical composition occur due to homogenization. The increase in viscosity that results from homogenization of tomato juice is hypothesized to be due to changes in physical properties of the chemical components. 
TABLE 8. RESULTS CF HOMOGENIZER RECONBINATION WITH TFREE SEPARATION TECHNIQUES

\begin{tabular}{|c|c|c|c|c|c|c|}
\hline & & Centrifuge & & $\begin{array}{c}\text { Conventional } \\
\text { Filter }\end{array}$ & $\begin{array}{c}\text { Microporous } \\
\text { Ejltter }\end{array}$ & \\
\hline $\begin{array}{l}\text { \&NTSS } \\
\text { Original Puree } \\
\text { Recombined Puree }\end{array}$ & $\begin{array}{l}9.0 \\
9.0\end{array}$ & $\begin{array}{l}8.8,9.8 \\
8.8,9.8\end{array}$ & $\begin{array}{l}10.2 \\
10.2\end{array}$ & $\begin{array}{l}9.6 \\
9.6\end{array}$ & $\begin{array}{l}9.2 \\
9.15\end{array}$ & $\underset{\mathrm{NA}}{9.2}$ \\
\hline $\begin{array}{c}\text { Viscosity (Bostwick, cm.) } \\
\text { Original Puree } \\
\text { Recombined Puree at: } \\
0.5 \mathrm{~min} \\
3 \mathrm{~min} \\
5 \mathrm{~min} \\
7 \mathrm{~min}\end{array}$ & $\begin{array}{l}5.03 \\
6.16\end{array}$ & $\begin{array}{l}5.4,5.0 \\
6.2 \star, 6.0 *\end{array}$ & $\begin{array}{l}5.12 \\
4.42 \\
3.93\end{array}$ & $\begin{array}{l}5.25 \\
4.37 \\
3.52\end{array}$ & $\begin{array}{l}5.27 \\
4.8 \\
4.75\end{array}$ & $\begin{array}{l}5.27 \\
4.57 \\
4.37\end{array}$ \\
\hline $\begin{array}{l}\text { Viscosity Change at: } \\
0.5 \text { min } \\
\begin{array}{ll}3 & \text { min } \\
5 & \text { min } \\
7 & \text { min }\end{array}\end{array}$ & $\begin{array}{c}\text { Loss }(+1.13 \mathrm{~cm}) \\
{[+22.5 \mathrm{E}]}\end{array}$ & $\begin{array}{l}\star \text { Loss }, * \text { Loss } \\
(+0.8,+1.0 \mathrm{~cm}) \\
{[+14.8 \%,+20 \%]}\end{array}$ & $\begin{array}{c}\text { Loss }(+0.27 \mathrm{~cm}) \\
{[+5.6 \%]} \\
\operatorname{Gain}(-0.43 \mathrm{~cm}) \\
{[-8.9 \%]} \\
\operatorname{Gain}(-0.92 \mathrm{~cm}) \\
{[-19.0 \%]}\end{array}$ & $\begin{array}{c}\operatorname{Gain}(-0.88 \mathrm{~cm}) \\
{[-16.8 \mathrm{z}]} \\
\operatorname{Gain}(-1.73 \mathrm{~cm}) \\
{[-33.0 \%]}\end{array}$ & $\begin{array}{c}\text { Gain }(-0.47 \mathrm{~cm}) \\
{[-8.9 \%]} \\
\text { Gain }(-0.52 \mathrm{~cm}) \\
{[-9.98]}\end{array}$ & $\begin{array}{r}\text { Gain }(-0.7 \mathrm{~cm}) \\
{[-13.38]} \\
\text { Gain }(-0.9 \mathrm{~cm}) \\
{[-17.1 \%]}\end{array}$ \\
\hline Separation Conditions & $\begin{array}{l}13.1000 \mathrm{rpm}^{\circ} \\
30 \mathrm{~min} \\
\text { Decant } 1 \mathrm{x}\end{array}$ & $\begin{array}{l}12,000 \mathrm{rpm}^{\circ} \\
30 \mathrm{~min} \\
\text { Decant } 1 x\end{array}$ & $\begin{array}{l}12,000 \mathrm{cpm} " \\
30 \mathrm{~min} \\
\text { Decant } 1 \mathrm{x}\end{array}$ & $\begin{array}{l}38 \text { micron } \\
30 \text { min } \\
23^{\prime \prime} \text { vacuum }\end{array}$ & $\begin{array}{l}0.2 \text { micron } \\
90-110 \text { psi } \\
(6.2-.6 \mathrm{bar}) \\
104-14 \mathrm{C}^{\circ} . \overline{\mathrm{F}} \\
\left(40-6.0^{\circ} \mathrm{C}\right. \\
3.6-4.6 \mathrm{gai} / \mathrm{min} \\
13.6--7.4 \mathrm{~L} / \mathrm{min}) \\
0.75 \mathrm{hr} \\
57-77 \mathrm{gal} / \mathrm{ft}^{2} \mathrm{day} \\
\left(97--31 \mathrm{~L} / \mathrm{m}^{2} \mathrm{hr}\right)\end{array}$ & $\begin{array}{l}0.2 \mathrm{micron} \\
88-120 \mathrm{psi} \\
(6.1-8.3 \mathrm{bar}) \\
115-149^{\circ} \mathrm{F} \\
\left(46-65^{\circ} \mathrm{C}\right) \\
4.2 \mathrm{gal} / \mathrm{min} \\
(15.9 \mathrm{~L} / \mathrm{min}) \\
0.75 \mathrm{hr} \\
54-83 \mathrm{gal} / \mathrm{ft}^{2} \mathrm{day} \\
\left(92-141 \mathrm{~L} / \mathrm{m}^{2} \mathrm{hr}\right)\end{array}$ \\
\hline
\end{tabular}

$\star$ Recombined puree heated to $82^{\circ} \mathrm{C}$ for $35 \mathrm{~min}$, before Bostwick measurenent.

$19,000 \pm 4000 \times$ gravity 
TABLE 9. CONSISTENCY MEASUREMENTS AND CHEMICAL ANALYSES OF HOMOGENIZED TOMATO PUREE SAMPLES

\begin{tabular}{|c|c|c|c|c|}
\hline Homogeñizati & Time & (Min) & & \\
\hline Characteristic & 0 & 3 & 5 & 7 \\
\hline Bostwick Consistency (cm) & 5.5 & 5.5 & 5.3 & 5.1 \\
\hline Serum Viscosity (sec) & 71 & 75 & 75 & 75 \\
\hline Precipitate wt. Ratio (\%) & 32.05 & 36.15 & 37.05 & 37.40 \\
\hline Total Solids ( $\left.\frac{\circ}{6}\right)$ & 12.1 & 12.0 & 12.1 & 12.2 \\
\hline Ash $\left(\frac{8}{6}\right)$ & 0.9 & 0.9 & 0.9 & 0.8 \\
\hline $\mathrm{pH}$ & 4.33 & 4.32 & 4.34 & 4.32 \\
\hline Titratable Acidity (ml) & 13.3 & 13.9 & 11.5 & 14.8 \\
\hline *Total Carbohydrates (gm/gm) & 0.329 & 0.311 & 0.316 & 0.325 \\
\hline *Total Pectin ( gm/gm) & 0.151 & 0.142 & 0.157 & 0.158 \\
\hline * Total Protein ( Kjeldahl)(gm/gm) & 0.158 & 0.163 & 0.159 & 0.156 \\
\hline
\end{tabular}

*Values expressed on a wet weight basis.

Additional Recombination studies. Studies were also undertaken examining the effect of the recombination technique alone upon the viscosity of the puree.

stomacher.

The effect of stomaching on puree viscosity ( 2 min) was examined. Three sets of samples were tested. In each case the Bostwick viscosity decreased $(0.8,0.83,0.68 \mathrm{~cm}$ increase) $[+14.5,+15.4,+12.6 \%]$.

In addition the effect on puree viscosity of stomaching for 2 min and letting the puite sit before measuring viscosity was examined. Six cans $(425 \mathrm{gms} / \mathrm{can})$ of puree at $8.9 \%$ NTSS were used. The original puree had a Bostwick viscosity of $5.47 \mathrm{~cm}$. Table 10 sumarizes results. The puree viscosity did not improve with time. 
TABLE 10. CHANGE IN VISCOSITY WITH STOMACHING 2 MINUTES AND SITTING

\begin{tabular}{cr} 
Time $(\mathrm{min})$ & Viscosity Change from Original Puree \\
\hline 0 & Loss $(+0.65 \mathrm{~cm})[+11.9 \%]$ \\
36 & Loss $(+0.45 \mathrm{~cm})[+8.2 \%]$ \\
72 & Loss $(+0.55 \mathrm{~cm})[+10.1 \%]$ \\
132 & Loss $(+0.70 \mathrm{~cm})[+12.8 \%]$
\end{tabular}

The effect of stomaching time on puree viscosity was also examined. Four cans $(425 \mathrm{gms} / \mathrm{can})$ of puree at $10.8 \%$ NTSS were used. The Bostwick of the original puree was measured. The rest of the puree was divided into $135 \mathrm{ml}$ portions and pairs of portions were stomached for $1,2,4$ and $8 \mathrm{~min}$. A Bostwick measurement was made on each portion. Viscosity decreased with stomacher mixing time (Fig. 9).

Homoqenizer.

The effect of homogenization time upon puree viscosity was examined. Four cans $(425 \mathrm{gms} / \mathrm{can})$ of puree at $10.2 \%$ NTSS were used. The Bostwick of the original puree was measured. The rest of the puree was divided into $270 \mathrm{ml}$ portions. One portion was homogenized for 1 min at setting no. 6 and Bostwick viscosity was measured. This process was repeated lur homogonizatinn times of 3, 5 and $7 \mathrm{~min}$. The viscosity decreased initially and then increased above the original value at 5 and $7 \mathrm{~min}$ (Fig. 10).

The effect of homogenization time on the viscosity of puree was studied using a different puree (containing $9.2 \frac{\circ}{6}$ NSS) and Bostwick was measured after 3,5 and $7 \mathrm{~min}$ of homogenization. The viscosity increased at $3 \mathrm{~min}$ with no further increase with longer mixing time (Fig. 11). 


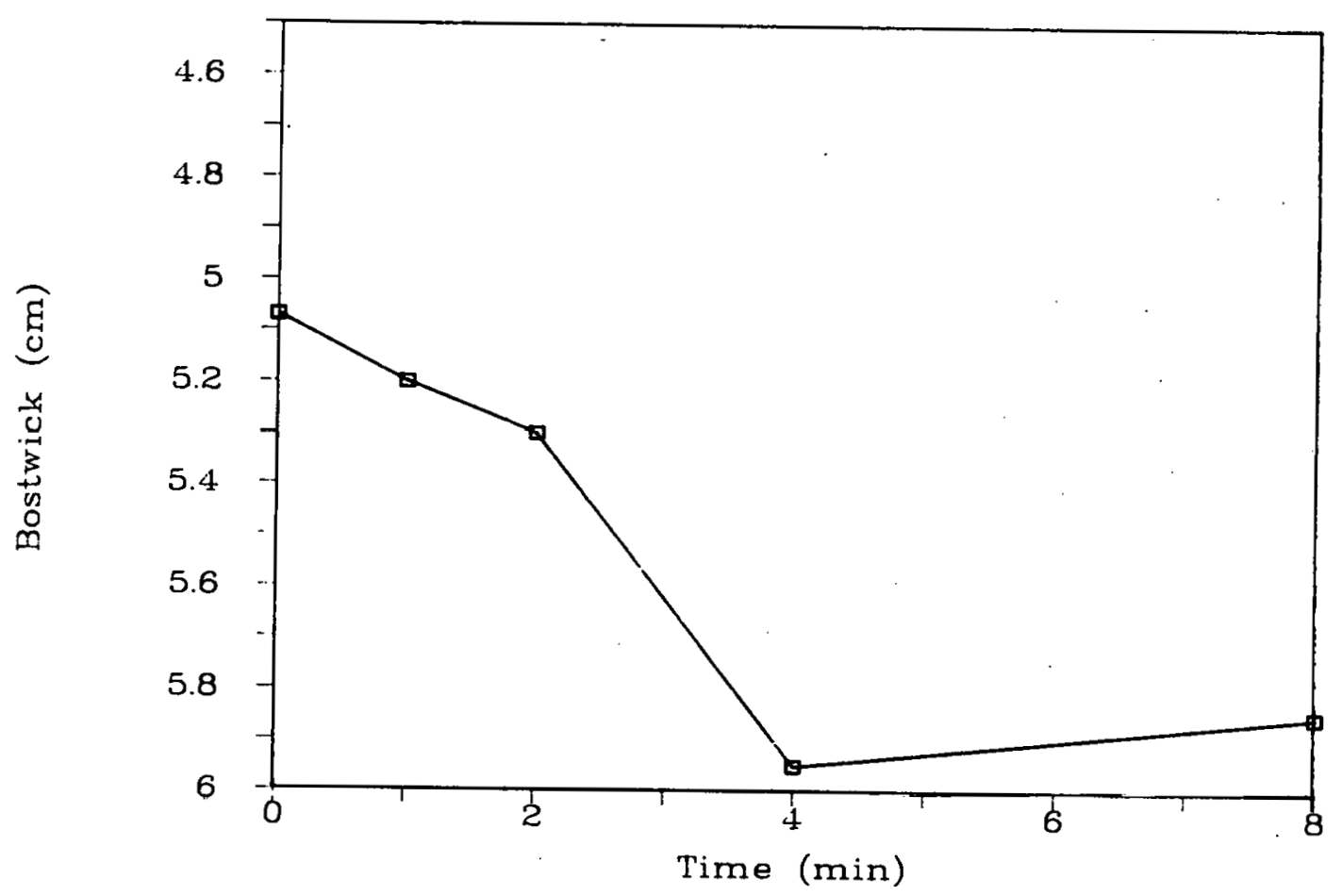

Figure 9 - Bostwick viscosity $(\mathrm{cm})$ versus stomacher mixing time (min) for unseparated puree (10.8\% NTSS). 
$-36-$

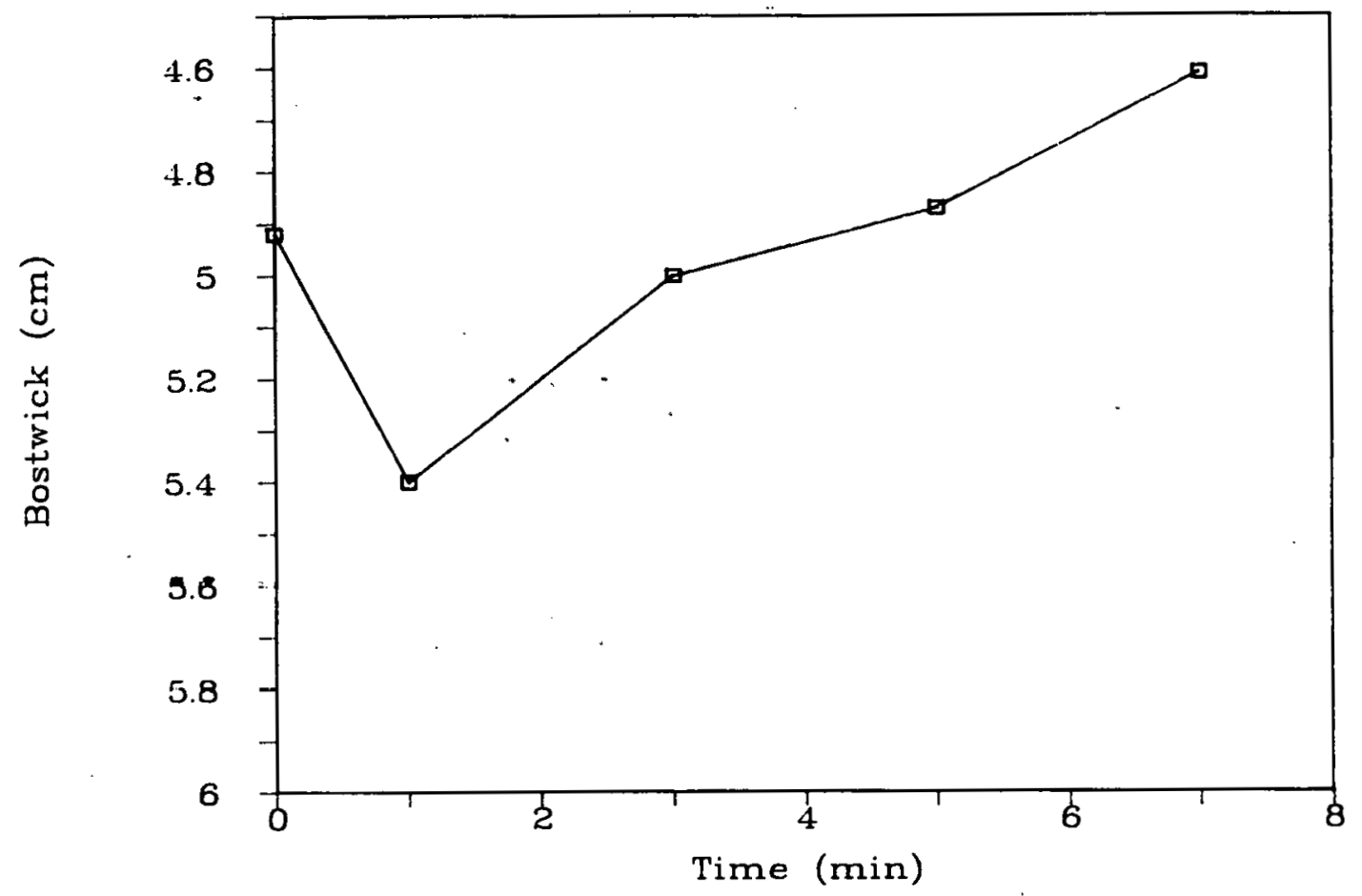

Figure 10 - Bostwick viscosity $(\mathrm{cm})$ versus homogenizing time (min) on unseparated puree (10.2\% NTSS).

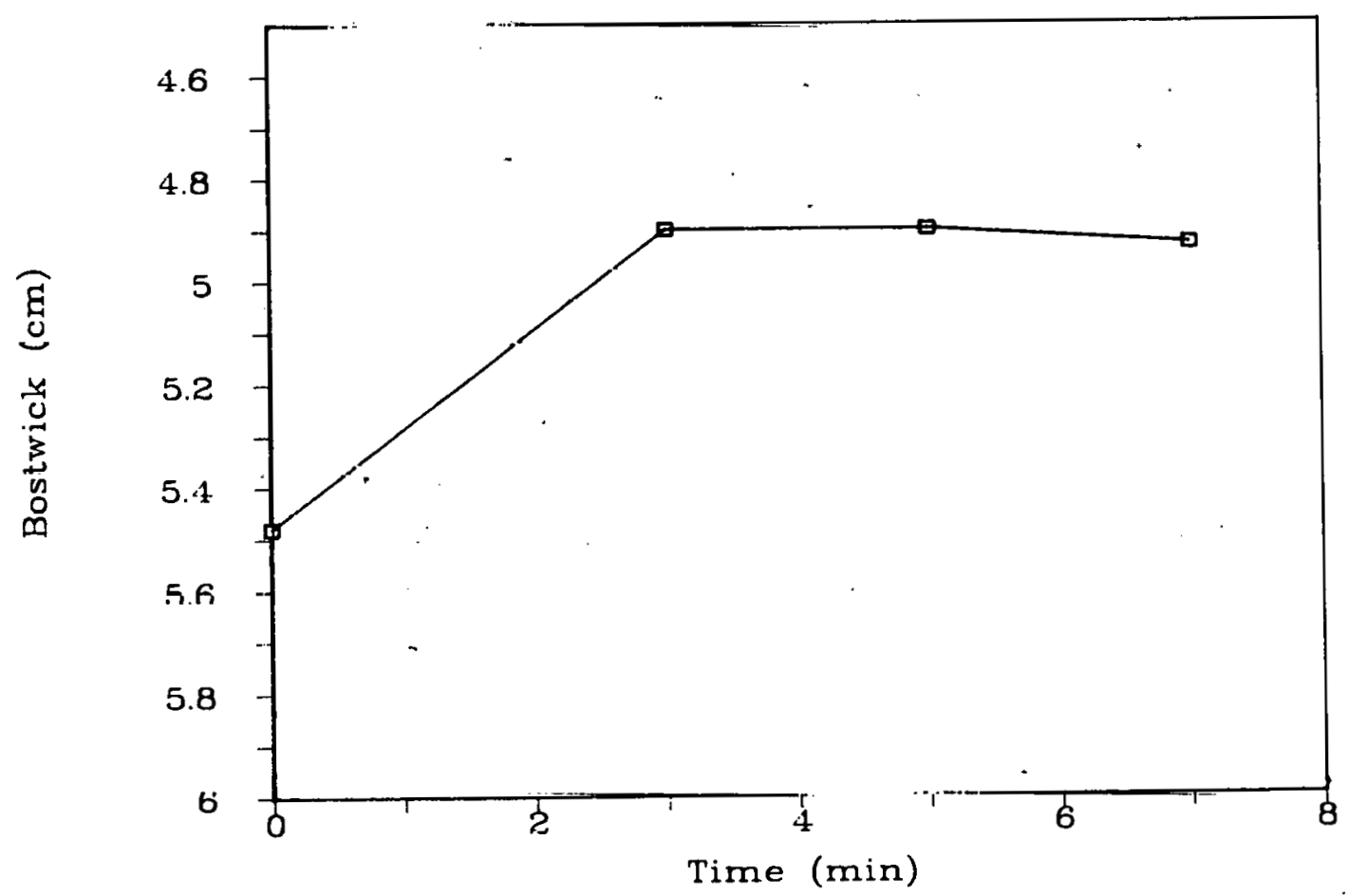

Figure 11 - Bostwick viscosity $(\mathrm{cm})$ versus homogenizing time (min) on unseparated puree ( 9.28 NTSS). 
Additional studies. Several studies were made of the effect of the microfiltration separation technique and the homogenization recombination technique on intact cells in puree.

Samples that had been separated by microfiltration were recombined by homogenization. The microfiltration caused a $52 \%$ broken cell count after $49 \mathrm{~min}$. However, in another study, $24 \mathrm{~min}$ of microfiltration caused a $59 \%$ broken cell count; an additional 23 min of operation increased the broken cell count to 69.8 . When recombined by homogenization there was only a slight increase in broken cells (to $57 \%$ in the first study; to $77 \%$ from $69 \%$ in the second study). Viscosity was restored upon recombination by. homogenization.

Examination of cells after 3,5 and $7 \mathrm{~min}$ of homogenization (without prior separation) showed no increase in the number of broken cells.

Separation Technique selection. Centrifugation separated the most serum, which is highly desirable. Centrifuges are readily available and familiar to the food industry. Consequently, this was the separation technique chosen for further study.

The microporous filter in conjunction with recombination by static mixer is a viable alletuative to the centrifuge., When recombining the two fractions produced by centrifugation, only a polytron homogenizer restored the viscosity to its original value. Homogenization would be an expensive recombination technique at the commercial scale. Microporous filters provided a good separation and the two fractions were recombined with a static mixer with full restoration of viscosity. Microfilters and static mixers are commercially available and may offer an economical alternative to centrifugation and homogenization. Further study of microfiltration and static mixing is warranted. 
Pulp Rinsing, serum Concentration and Recombination studies

Tomato puree ( $\sim 10 \%$ NTSS) was separated into two fractions by centrifugation. The pulp obtained was rinsed and the rinse water added to the serum. The rinsing step is designed to remove components from the pulp which might be damaged in drying. The rinse/serum fraction was then concentrated to 30,50 , and $70 \%$ NTSS by evaporation. These fractions were all characterized.

In addition, tomato serum was concentrated by hyperfiltration to approximately $20 \%$ NTSS. This fraction could be further concentrated by evaporation.

The two fractions obtained by centrifugation, rinsing, and rinse/ serum concentration were recombined to reproduce the original puree solids level and evaluated.

Pulp Rinsing. Five cans $(2900 \mathrm{gms} / \mathrm{can})$ of puree were used rui this step. The puree was centrifuged at $9500 \mathrm{rpm}(12,000 \pm 2700$ $x$ gravity) for $40 \mathrm{~min}$. Tomato serum was decanted and volume measured. Pulp was weighed for separation dta. Water equal to approximately one-half the serum volume was stirred into the pulp (rinsing step). This rinsed pulp was recentrifuged as above, and rinse water decanted. The NTSS of the rinse water was measured and the rinsing repeated until the NTSS measured <1\%. This process required 5 to 6 rinsing steps. The rinse water and serum were combined to produce a rinse/serum fraction.

The separation obtained on a weight basis from centrifuging and rinsing was $21.7 \%$ pulp, $78.3 \%$ serum. The original puree and the fractions obtained upon separation and rinsing were characterized and results are in Table 11. Samples were frozen for later use. 
Serum Concentration. The rinse/serum fraction from the pulp rinsing step was concentrated to 30,50 and $70 \%$ NTSS using a rotary evaporator (Buchi) with vacuum. The water bath temperature was $52-56^{\circ} \mathrm{C}$ during concentration. Batches of about $600 \mathrm{ml}$ rinse/serum were concentrated to about $30 \mathrm{mls}$ of $30 \%$ NTSS. Then several of these batches were combined to concentrate to 50 and $70 \%$ NTSS.

One hundred ml samples of each of the three levels were obtained. The remaining serum was concentrated to $50 \%$ NTSS and frozen. Characterization of these samples was performed and are listed in Table 11. 
TABLE 11. CHARACTERIZATION OF PUREE AND RINSED AND ODNCENTRATED FRACTIONS

\begin{tabular}{|c|c|c|c|c|c|c|c|c|c|}
\hline I.D. & $\begin{array}{c}\text { NTSS, } \\
\frac{0}{8} \\
\end{array}$ & $\begin{array}{l}\text { Protein } \\
\frac{\circ}{6}\end{array}$ & $\begin{array}{c}\text { Pectin } \\
\% \\
\end{array}$ & \begin{tabular}{c} 
Sucrcse, \\
$\substack{o \\
\hdashline}$ \\
\end{tabular} & $\begin{array}{c}\text { Glucose, } \\
:\end{array}$ & $\begin{array}{c}\text { Fruistose, } \\
8\end{array}$ & $\begin{array}{c}\text { Citríc } \\
\text { Acid } \\
q\end{array}$ & $\begin{array}{l}\text { Malic } \\
\text { Acid, } \\
\quad 8 \\
\end{array}$ & $\begin{array}{l}\text { Pyroglu- } \\
\text { tamic } \\
\text { Acid }\end{array}$ \\
\hline Puree & 9.5 & 1.65 & 0.63 & $<0.1$ & 2.63 & 2.92 & $\mathrm{NA}$ & NA & 0.17 \\
\hline $\begin{array}{l}\text { Pulp } \\
\text { Rinsed } \\
(11-25-85)\end{array}$ & 0.8 & 1.97 & 0.94 & $<0.1$ & 0 & 0 & 0 & 0 & 0 \\
\hline $\begin{array}{l}\text { Pulp } \\
\text { Rinsed } \\
\text { (No Date) }\end{array}$ & 0.8 & $\mathrm{NA}$ & 1.35 & $\mathbf{N A}$ & NA & $\mathbf{N A}$ & NA. & NA & NA \\
\hline $\begin{array}{l}\text { Rinse/ } \\
\text { Serum }\end{array}$ & 5.2 & 0.66 & $<0.1$ & $<0.1$ & 0.81 & 0.91 & NA & 0 & 0.01 \\
\hline $\begin{array}{l}30 \% \text { Rinse/ } \\
\text { Serum }\end{array}$ & $30 \pm 3$ & $4 . .22$ & 1.44 & $<3.1$ & 8.31 & 9.24 & 1.88 & 0.16 & 0.08 \\
\hline $\begin{array}{l}50 \% \text { Rinse/ } \\
\text { Serum }\end{array}$ & $50 \pm 4$ & 7.50 & 2.49 & $<0.1$ & 13.5 & 15.3 & 3.28 & 0.24 & 0.06 \\
\hline $\begin{array}{l}70 \% \text { Rinse/ } \\
\text { Serum }\end{array}$ & $70 \pm 5$ & 10.40 & 3.51 & NA & NA & $\mathrm{NA}$ & $\mathrm{NA}$ & $\mathrm{NA}$ & $\mathrm{NA}$ \\
\hline
\end{tabular}


Serum Concentration by Initial Hyperfiltration...

Studies were undertaken on the feasibility of using hyperfiltration to initially concentrate tomato serum prior to evaporation. Tomato serum produced by ultrafiltration and centrifugation were concentrated by hyperfilter. Fresh cold break tomato juice ( $\sim$ \% NSS) was separated into serum and pulp. fractions by ultrafilter (CARRE, Inc.) and fresh hot and cold break tomato juice was separated by centrifuge (Alfa-Laval). Most centrifuged serum was produced at $2000 \mathrm{rpm}(2,200 \mathrm{x}$ gravity), but one test (23 hrs.) involved serum which was recentrifuged at 12,200 rpm (maximum $20,000 \times$ gravity).

Testing with the serum from ultrafiltration and 2000 rpm centrifugation lasted 89 hrs. Operating conditions were at 800 psi (55 bar) 104 and $140^{\circ} \mathrm{F}\left(40\right.$ and $\left.60^{\circ} \mathrm{C}\right)$ in a recycle mode. The flux declined with time from $32 \mathrm{gal} / \mathrm{ft} \mathrm{t}^{2} \mathrm{day}\left(54 \mathrm{~L} / \mathrm{m}^{2} \mathrm{hr}\right)$ to $7 \mathrm{gal} / \mathrm{ft}^{2}$ day $\left(12 \mathrm{~L} / \mathrm{m}^{2} \mathrm{hr}\right)$. Mid-way through this test permeate was diverted from the system allowing concentration to take place to $20.9 \%$ NTSS. The flux declined from $12 \mathrm{gal} / \mathrm{ft}^{2} \mathrm{day}\left(20 \mathrm{~L} / \mathrm{m}^{2} \mathrm{hr}\right)$ to. 2 gal/ft ${ }^{2}$ day $\left(3 \mathrm{~L} / \mathrm{m}^{2} \mathrm{hr}\right)$. Additional analysis of the data is necessary to predict economic feasibility.

Testing ( 23 hrs.) with the double centrifuged juice did not produce significantly different results. Operating conditions were the same at the higher temperature. The flux declined from 17 to $12 \mathrm{gal} / \mathrm{ft} \mathrm{t}^{2} \mathrm{day}\left(29\right.$ to $\left.20 \mathrm{~L} / \mathrm{m}^{2} \mathrm{hr}\right)$.

Rejection of NTSS was high during all testing. The permeate had 0.2 to $<0.1 \%$ NTSS. 
Recombination and Evaluation. The fractions of concentrated rinse/serum and rinsed pulp were recombined to make puree. Three studies were performed.

In the first study, the NTSS and TS of the fractions and original puree was measured to calculate the amounts to be combined with water. The calculated amounts were recombined and mixed lightly giving a piroduct with a "juirelike" appearance. The recombined puree had NTSS of $8.8 \%$; the original puree had NTSS of $9.5 \%$. Consequently more rinse/serum and pulp were added to the mixture, based instead upon 50\% NTSS and 50\% TS in the rinse/serum, since these two analytical procedures are subject to larger experimental error when the solids are at such high levels. This mixture (No. 2) was homogenized for $3 \mathrm{~min}$, followed by measurement of Bostwick and NTSS (Table 12).

A third mixture was made by adding $10 \mathrm{gm}$ of rinsed pulp to Mixture.No. 2 and homogenizing for $3 \mathrm{~min}$. Mixture No. 4 was made by adding $10 \mathrm{gm}$ of rinsed pulp to Mixture No. 3. Table 12 shows results of Bostwick and NTSS analysis. Mixture 4 Boxtwick results are very close to that of the original puree. Mixture 4 also contains $21.5 \%$ pulp (by weight) which is very close to the percent pulp obtained in the separation upon centrifuging and rinsing $(21.7 \%)$. 
TABLE 12. ORIGINAL AND RECOMBINED PUREES

Original

Puree

Mixture 1 Mixture 2 Mixture 3 Mixture 4

wt $\%$ rinse/ serum - -

wt $:$ pulp

17.3

18.8

18.2

17.4

Bostwick $(\mathrm{cm})$

13.7

15.2

17.9

21.5

NTSS $(\%)$

5.5

(assumed $>15$ )

11.4

8.3

5.8

8.8

9.5

9.6

9.3

The second study used fraction amounts close to those of Mixture No. 4 in the previous study, but with a slightly higher amount of rinse/serum, since the NTSS of Mixture No. 4 was somewhat lower than the original puree. The new mixture was homogenized for 3 min followed by measurement of Bostwick, NTSS and TS. A second batch of the mixture was made and homogenized for $7 \mathrm{~min}$. Table 13 shows results. At 7 min homogenization, the Bostwick obtained was better than the original.

TABLE 13. ORIGINAL AND RECOMBMINED PUREES AFTER DIFFERENT HOMOGENIZATION TIMES

\begin{tabular}{cc} 
Original & $\begin{array}{c}\text { Reconstituted } \\
\text { Homogenized }\end{array}$ \\
Puree & $3 \mathrm{~min} \quad 7 \mathrm{~min}$ \\
\hline
\end{tabular}

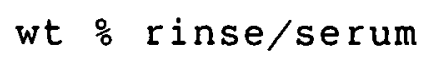

$\begin{array}{lll}- & 18.8 & 18.8\end{array}$

wt $\%$ pump

$--$

21.5

32.5

Bostwick $(\mathrm{cm})$

5.5

5.6

5.35

NTSS (\%)

9.5

9.7

9.6

TS $\left(\frac{\circ}{6}\right)$

10.77

10.91

11.00 
In the third study, the centrifugation, rinsing and concentration steps were repeated with careful monitoring of the addition and removal of water, so that a direct calculation could be made of the amount of concentrated rinse/serum ( $21 \%$ NTSS) needed to be used for reconstituting to the original puree solids level.

Using the weight fractions measured during the separation step as a guide, $82.99 \mathrm{gm}$ rinsed pulp, $142.17 \mathrm{gm}$ concentrated rinse/ serum, and water to produce $350 \mathrm{gm}$ of puree were combined and homogenized for $7 \mathrm{~min}$. This was repeated with a second batch. Bostwick, NTSS, and TS were meásured (Table 14). The samples were refrigerated for 3 days and Bostwick was remeasured. The first batch did not totally recover the viscosity, but the second batch did. Viscosity of both improved after refrigerated storage.

TABLE 14. ORIGINAL AND RECOMBINED PUREES

BEFORE AND AFTER REFRIGERATED STORAGE

Recombined and Homogenized

Original sample 1 Sample 2

Puree Initial Refig. Initial Refrig.

\begin{tabular}{lccccc}
\hline Bostwick $(\mathrm{cm})$ & 5.45 & 6.33 & 5.65 & 5.50 & b.30 \\
NTSS(\%) & 9.1 & 9.1 & - & 9.2 & - \\
TS(\%) & 10.81 & 10.84 & - & 10.96 & - \\
wt $\%$ rinse/serum & - & 40.6 & - & 40.6 & - \\
wt \% rinsed pulp & - & 23.7 & - & .23 .7 & -
\end{tabular}


Tomato Maturity study

The sub-contractor performed a study to quantitate changes in product viscosity and in protein and pectin.contents as tomatoes ripen. To better control the consistency of tomato products, the factors which determine product viscosity must be known and understood. The changes in these factors during ripening and processing of the tomato must also be known. Pectic substances and proteins appear to both be important factors influencing tomato product consistency. However, these two components have not been well quantitated and characterized to examine how they relate to viscosity changes during maturation of the fruit.

Tomatoes of the variety 6203 were grown in the Purdue University horticulture greenhouses. The tomatoes were harvested at various stages of maturity, as measured by date of pollination. Tomatoes for Replication I and Replication II were harvested at stages 5 and 6 of maturity, respectively, as shown below:

\begin{tabular}{cc} 
Stage of & Days after \\
Maturity & Blossoming \\
\hline 1 & 34 (green) \\
2 & 41 \\
3 & 43 \\
4 & 45 \\
5 & 47 (ripe) \\
6 & 49 (overripe)
\end{tabular}

All samples were subjected to the hot break process then analyzed for the following: 


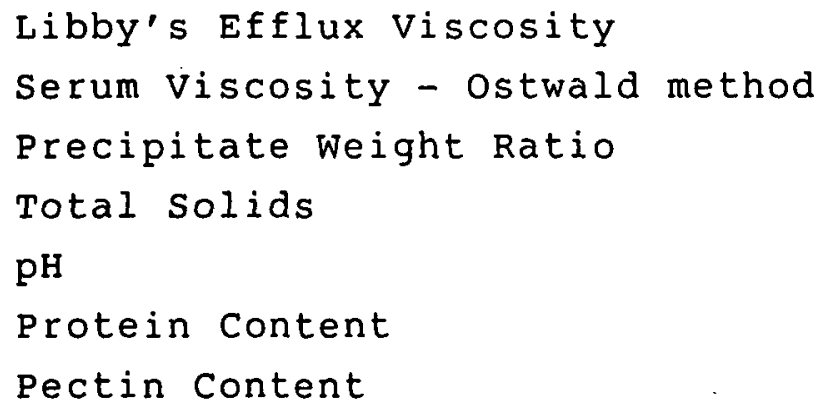

All data points shown are the average of duplicate determinations. The percent protein in the serum (Fig. 12), Libby's efflux viscosity (Fig. 13), and serum viscosity (Fig. 14) decreased sharply between maturity stages 1 and 3 . Levels were all minimized at stages 4 and 6 , and increased slightly in stage 5 . The pattern was similar for precipitate weight ratio (Fig. 15). While serum protein and all measures of viscosity were higher at stage 5 than at stages 4 and 6 , serum pectin (Fig. 16) was minimized at stage 5 . These results suggest that more than just pectin content determines viscosity. The percent protein in the serum more closely followed the changes in viscosity than did percent pectin. The pH of the juice or serum showed little change during maturation (Table 15). Hunter color changes occurred as expected during maturation (Table 16) after stage 1. Total solids in the juice generally decreased continually during maturation (Table 17 ). 


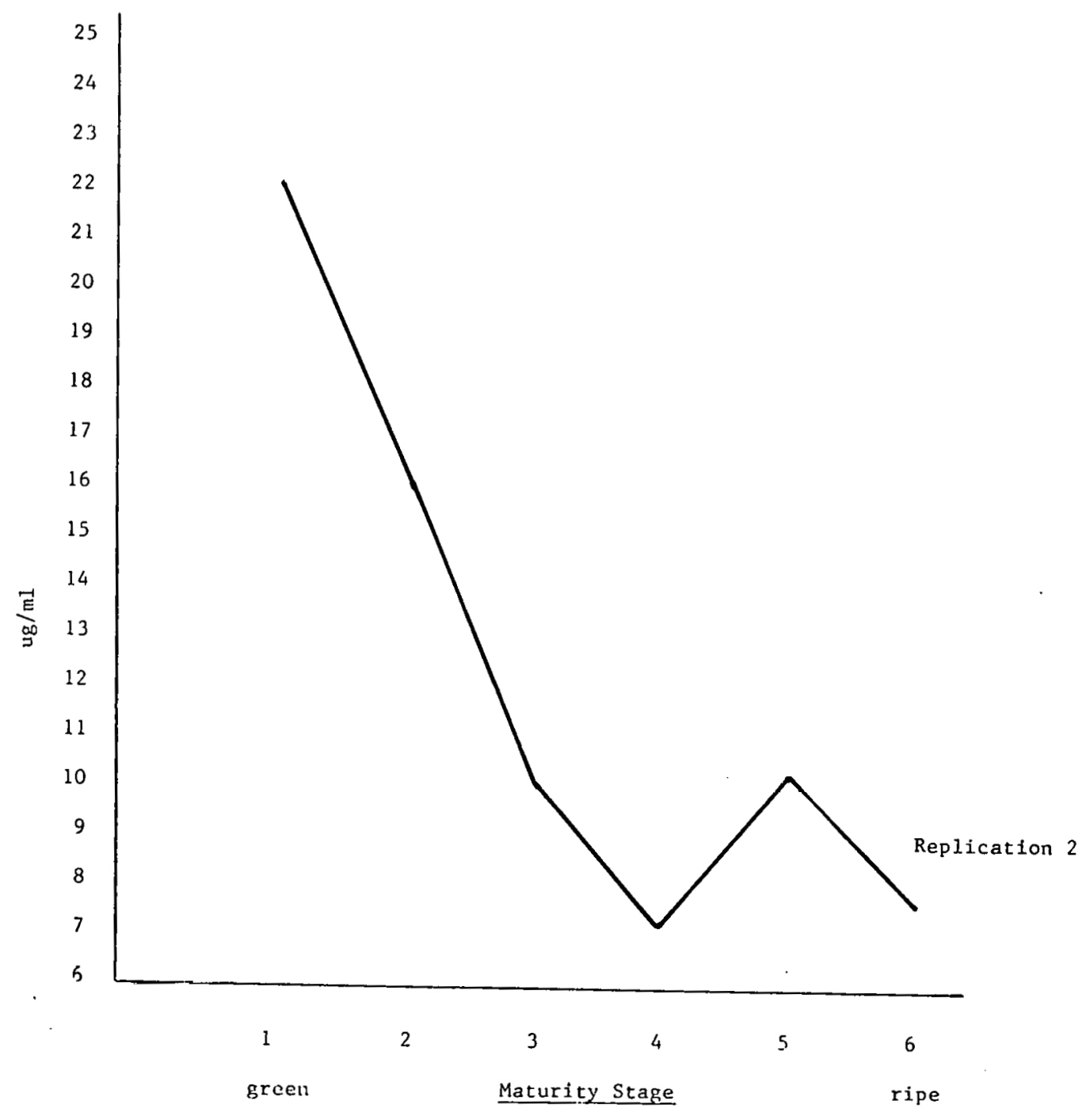

Figure 12 - Percent protein in serum versus maturity stage (Bradford method). 
$-48-$

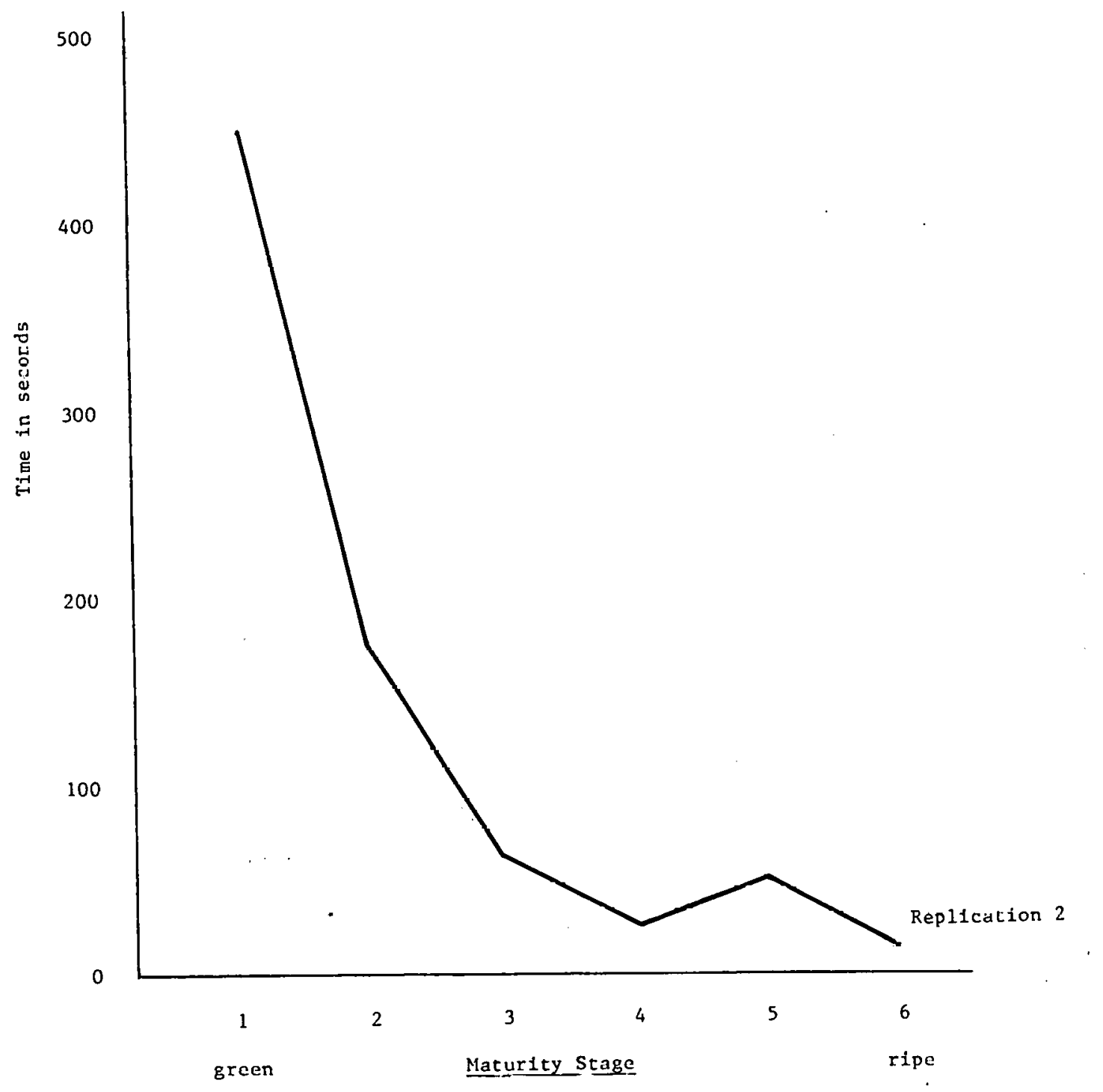

Figure 13 - Libby's efflux viscosity versus maturity stage. 


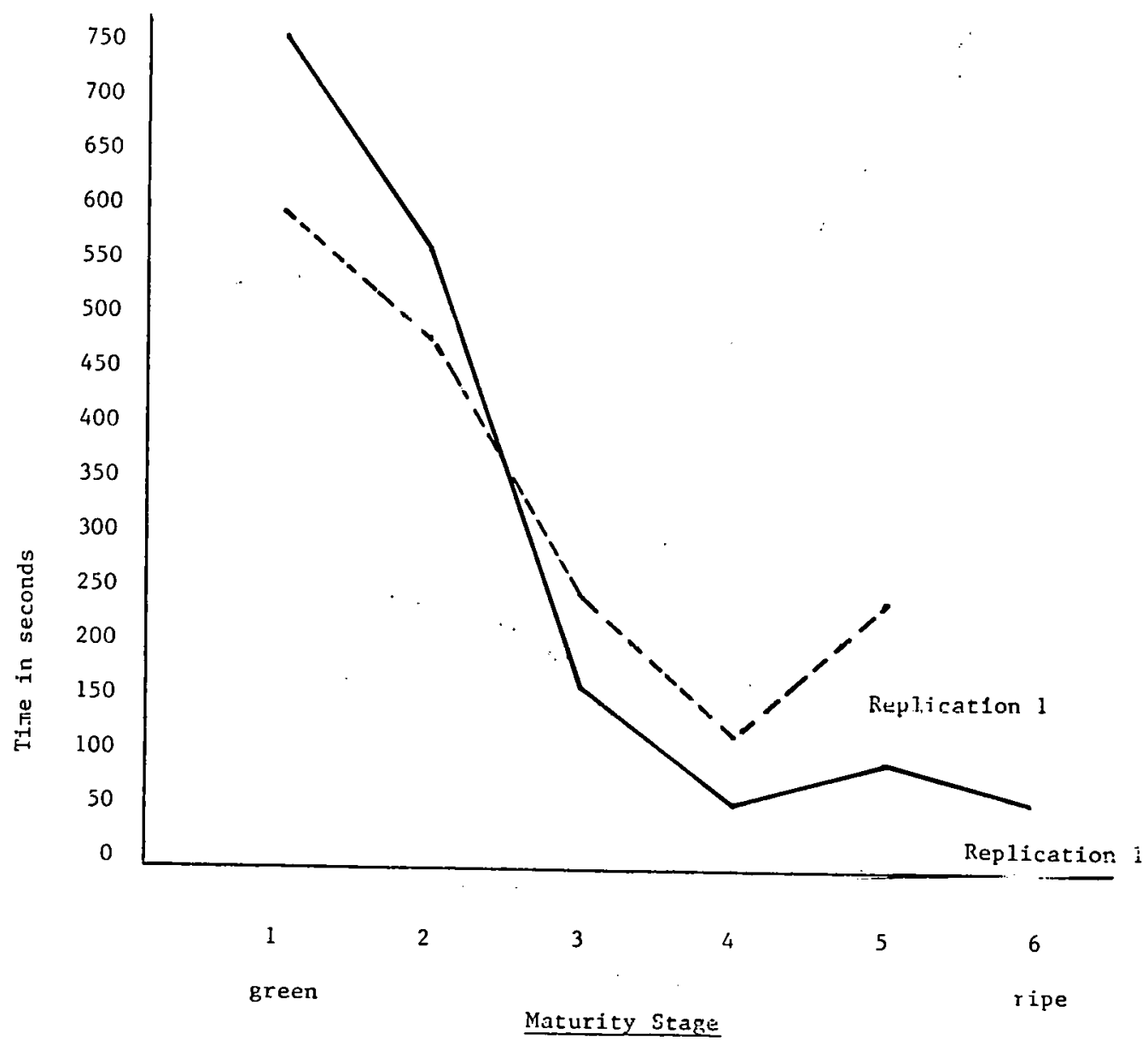

Figure 14 - Serum viscosity versus maturity stage (Ostwald method). 


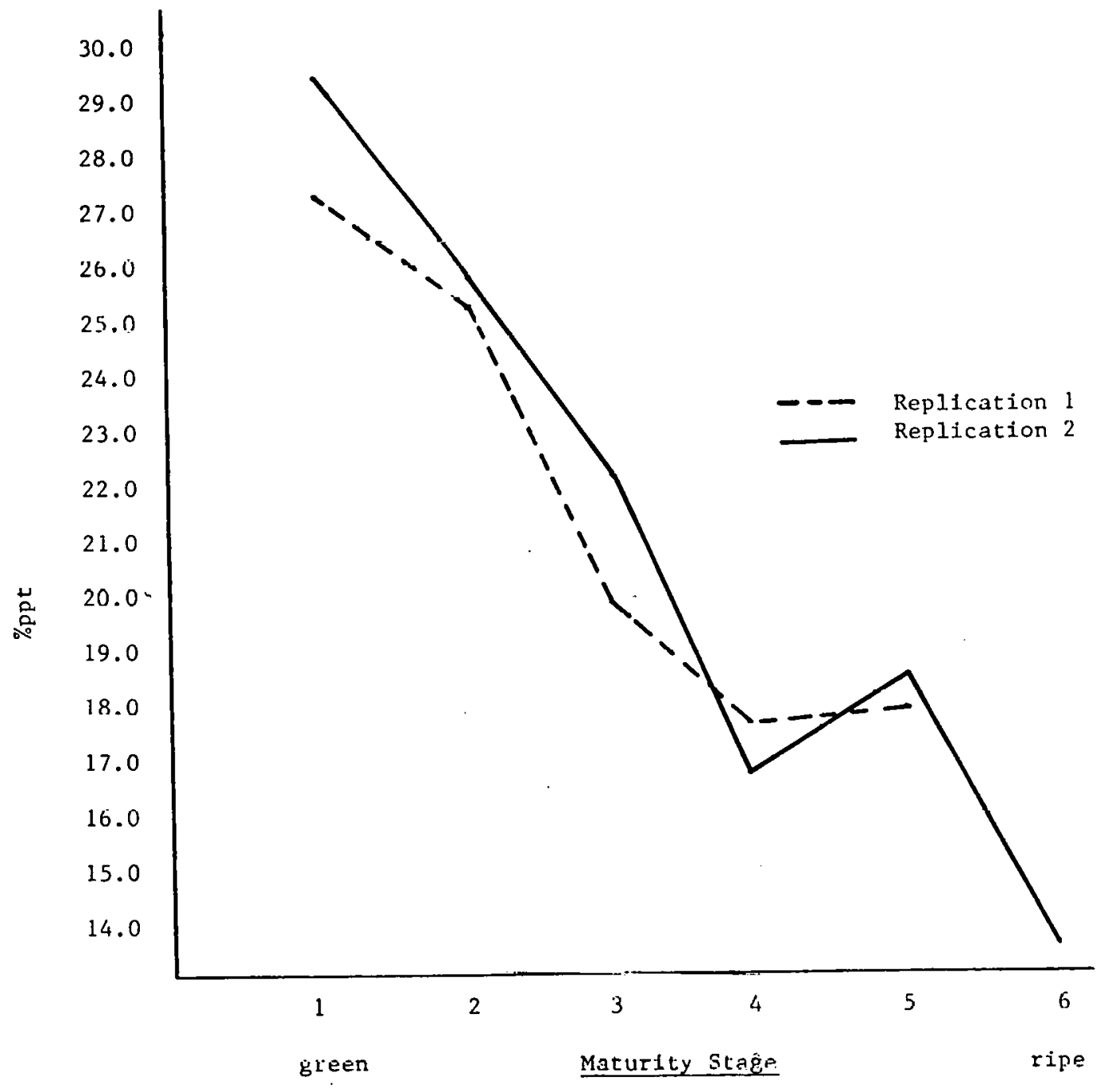

Figure 15 - Precipitate weight ratio versus maturity stage. 


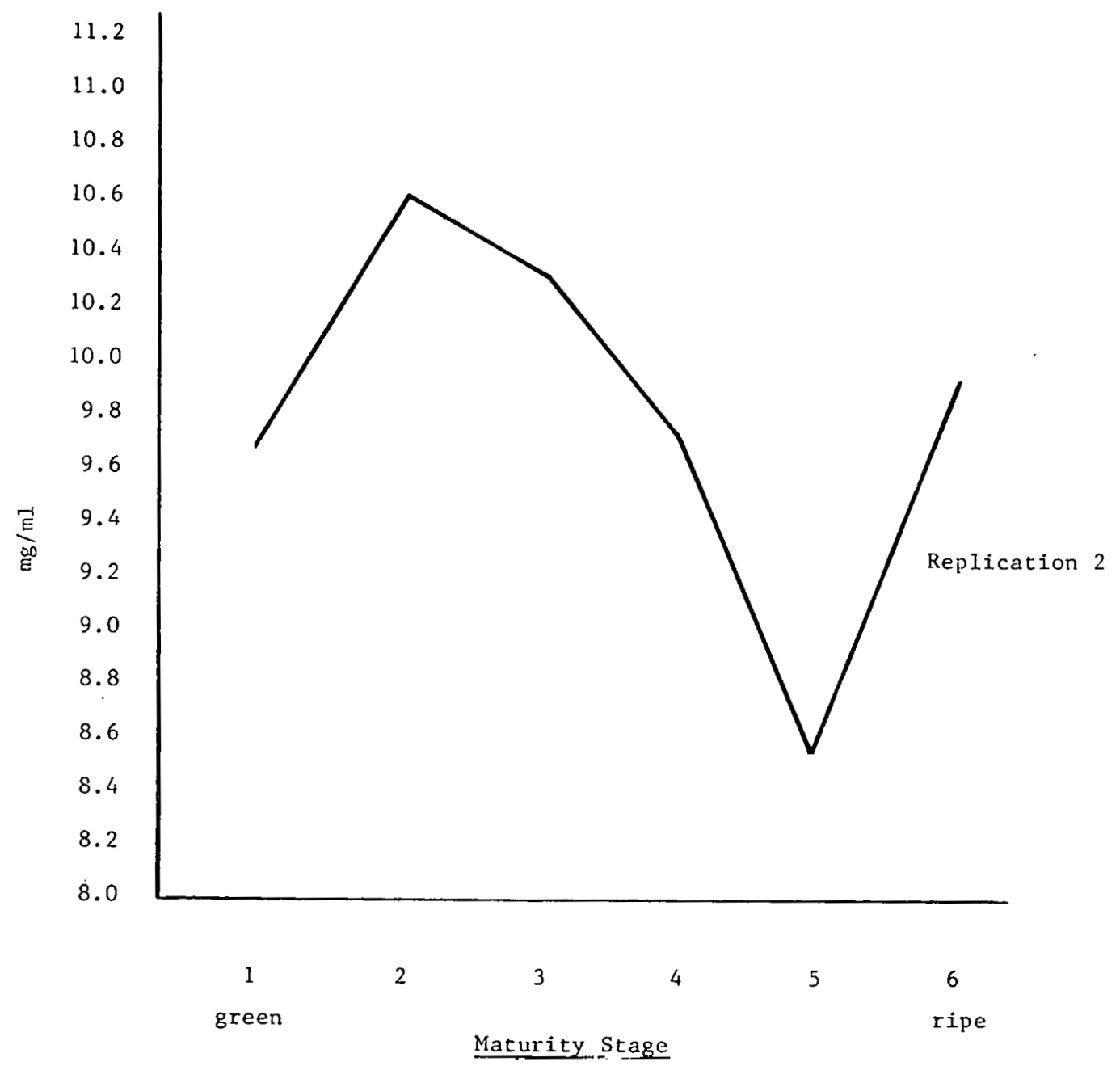

Figure 16 - Percent pectin in serum versus maturity stage (carbazole $/ \mathrm{H}_{2} \mathrm{SO}_{4}$ method). 
TABLE 15. PH OF TOMATO JUICE AND SERUM HARVESTED AT SIX STAGES OF MATURITY

\begin{tabular}{ccc}
\hline Maturity stage & Juice & pH (Replication II) \\
\hline 1 (green) & 4.51 & 4.50 \\
2 & 4.35 & 4.33 \\
3 & 4.31 & 4.27 \\
4 & 4.28 & 4.28 \\
6 (ripe) & 4.36 & 4.34 \\
\hline
\end{tabular}

TABLE 16. TOMATO JUICE HUNTER COLOR READINGS OF TOMATOES HARVESTED AT SIX STAGES OF MATURITY

\begin{tabular}{ccccc}
\hline Maturity stage & Hunter & Color Readings & (Replication II) \\
\hline 1 (green) & L & a & b & a/b \\
2 & 48.8 & -3.3 & 22.7 & -.145 \\
3 & 40.9 & 10.6 & 20.3 & .522 \\
4 & 30.7 & 25.6 & 14.1 & 1.82 \\
5 (ripe) & 28.1 & 28.3 & 13.1 & 2.16 \\
6 & 27.0 & 28.6 & 12.7 & 2.25 \\
& 26.1 & 29.8 & 12.7 & 2.35 \\
\hline
\end{tabular}

TABLE 17. PERCENT TOTAL SOLIDS IN TOMATO JUICE ADJUSTED TO 5.5 BRIX FROM TOMATOES HARVESTED AT VARIOUS STAGES OF MATURITY

\begin{tabular}{ccc} 
Maturity stage & $\begin{array}{c}\text { l'otal solids ( } \\
\text { Replication I }\end{array}$ & $\begin{array}{c}\text { in romato Juice } \\
\text { Replication II }\end{array}$ \\
\hline 1 (green) & 6.46 & 6.45 \\
2 & 6.29 & 6.21 \\
3 & 6.09 & 6.06 \\
4 & 5.92 & 5.95 \\
5 (ripe) & 5.96 & 5.91 \\
6 & --- & 5.85
\end{tabular}


PHASE II

Studies were performed with commercially-prepared tomato puree ( $9 \%$ NTSS) and with fresh tomato juice. Commercially-prepared tomato puree was used because of its year-round availability and because its viscosity can be easily measured by means of the Bostwick procedure.

\section{Separation study}

Canned puree $(320 \mathrm{lb})(140 \mathrm{~kg})$ was separated into pulp and serum fractions using a decanter centrifuge. Puree was fed to the cen-trifuge at $\sim 1 \mathrm{gal} / \mathrm{min}(3.8 \mathrm{~L} / \mathrm{min})$. Centrifuging was done at $\operatorname{maxi}-$ mum rpm ( $\sim 3500 \mathrm{x}$ g) with slow scroll speed. Most of the pulp fraction was removed from the decanter (the centrifuge was not dismantled, so some pulp remained inside) and placed in a vat. Rinse water $\left(\sim 47^{\circ} \mathrm{C}\right)$ equal in weight to the serum fraction removed was added to the vat and mixed. This mixture was centrifuged as above. The rinse water leaving the centrifuge was added to the serum, producing rinse/serum. The rinsing procedure was repeated. A total of $480 \mathrm{lb}(220 \mathrm{~kg})$ of water was added during the two rinse cycles, producing $710 \mathrm{lb}(320 \mathrm{~kg}) \mathrm{rinse} / \mathrm{serum}$ and $90 \mathrm{lb}$ $(40 \mathrm{~kg})$ rinsed-pulp, thus ending with $28 \%$ of the original puree weight as rinsed-pulp. Results of analysis of samples are given in Table 18 . 
TABLE 18. CHARACTERIZATION OF PUREE AND FRACTIONS

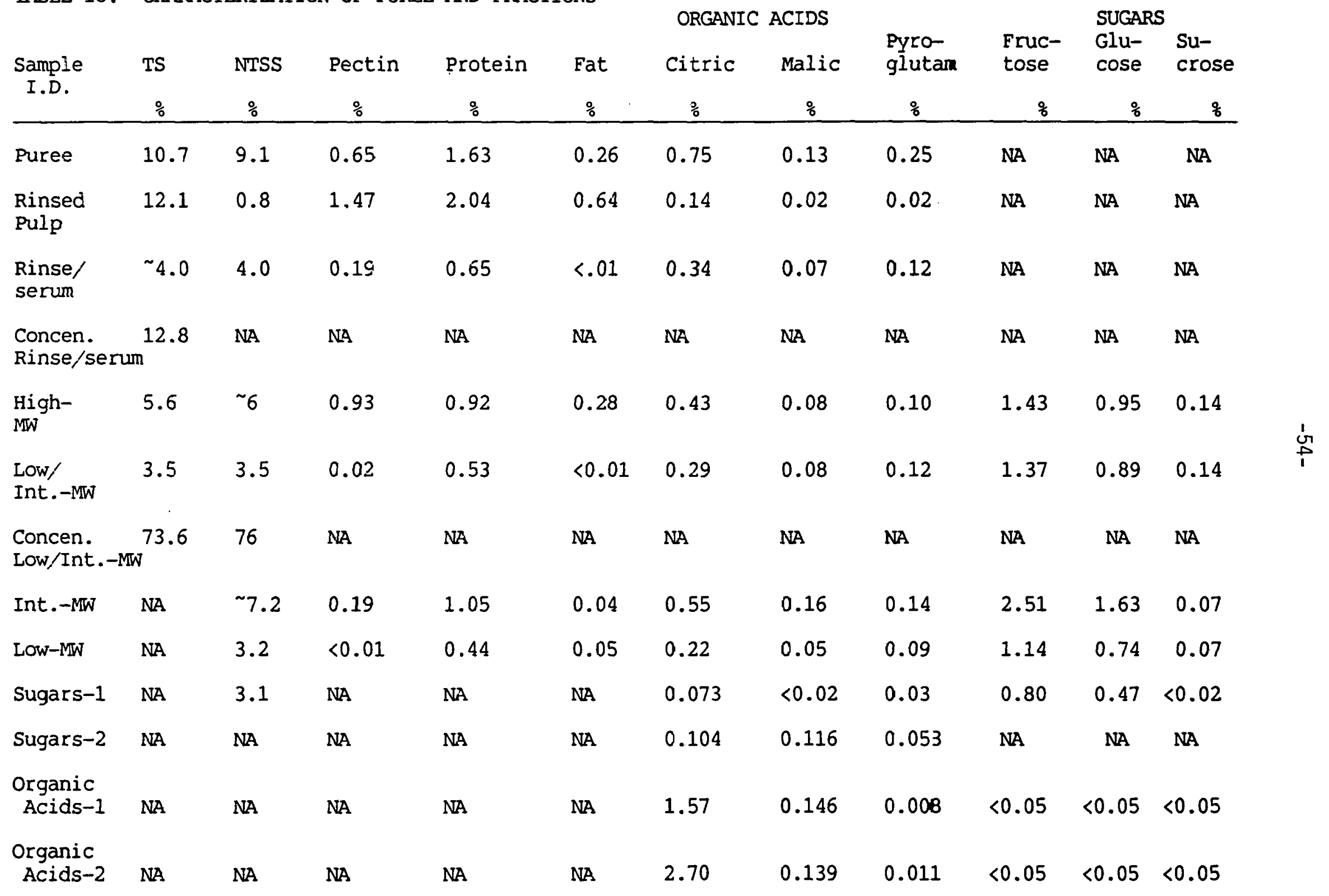


Ultrafiltration and Concentration studies

The rinse/serum fraction was further fractionated by ultrafiltration. Some fractions obtained were concentrated.

Initial 2000-MW Membrane Ultrafiltration. In initial ultrafiltration studies, a 2000-MW membrane was chosen to fractionate the rinse/serum into a low-MW fraction and a high/intermediate-MW fraction. This approach was expected to remove a large fraction of the sugar from the rinse/serum, so that a sample suitable for molecular weight distribution analysis would be produced (Sugars interfere with the MW distribution determination).

A quantity of the rinse/serum $(26.6 \mathrm{lb}, 12.06 \mathrm{~kg})$ was concentrated in batch mode for 4 hrs using GR90PP membranes $\left(0.18 \mathrm{~m}^{2}\right.$ total membrane area), at $25^{\circ} \mathrm{C}, 8 \mathrm{~L} / \mathrm{min}, 290 \mathrm{psi}(2 \mathrm{MPa})$. The flux decreased from 9 to $5 \mathrm{gal} / \mathrm{ft}^{2}$ day $\left(15\right.$ to $8 \mathrm{~L} / \mathrm{m}^{2} \mathrm{hr}$ ). Sugar rejection (as measured by NTSS) was higher than anticipated (45 to 57\%); only 55 to $43 \%$ of sugars permeated. The initial rinse/ serum concentration was $4 \%$ NTSS (Table 18); the resulting permeate had a concentration of 2.2 to $3.1 \%$ NTSS, and the resulting retentate (high/intermediate $M W$ ) had a concentration of $7.3 \%$ NTSS. The sugars may have formed complexes with high-molecularweight components, thus producing a higher-than-expected sugar rejection (based upon lie molecular-weight-cutoff of the membranes).

The membranes were cleaned with detergent and flux and sugar rejection were measured using a pure sugar solution (6\% fructose) at 145 and 290 psi ( 1 and $2 \mathrm{MPa}$ ). The observed rejection ( 15 and $19 \%$ at the two pressures, respectively) was lower than that obtained with rinse/serum but higher than expected. 
The retentate (obtained from batch mode runs with rinse/serum) was diafiltered in order to remove a larger fraction of sugars from the retentate. In order to do this water was added to the retentate in an amount equal to the weight of the permeate removed in the batch runs.

This solution ( $2.5 \%$ NTSS) was ultrafiltered in batch diafiltration mode for $4 \mathrm{hrs}$. Flux varied from 8 to $4 \mathrm{gal} / \mathrm{ft}^{2}$ day $(14$ to $7 \mathrm{~L} / \mathrm{m}^{2} \mathrm{hr}$ ). Sugar rejection (by NTSS) was still high (60 to $64 \%$ ). The permeate had a concentration of 1 to $1.7 \%$ NTSS and the final retentate had a concentration of $5.5 \%$ NTSS. The diafiltration procedure was repeated. Flux varied from 6 to 4 gal/Fl ${ }^{2}$ day ( 10 to $7 \mathrm{~L} / \mathrm{m}^{2} \mathrm{hr}$ ). Sugar rejection (by NTSS) was 54 to $73 \%$. The final retentate had a concentration of $3.3 \%$ NTSS. During the two diafiltrations, permeate equal to $97 \%$ of the added water weight was removed.

The above procedure (batch run and two diafiltrations) removed about $70 \%$ of the sugars (by NTSS) Irum the feed (rinsc/cerum). The final retentate weight was $37 \%$ of the initial feed (rinse/ serum) weight. The membranes were cleaned with an enzyme cleanes (Monarch DDS), which resulted in a significant water flux increase. However, a test with $6 \%$ fructose again showed only a slight decrease in rejection: 10 and $17 \%$ at 145 and 290 psi ( 1 and 2 MPa), respectively.

The above procedure was repeated with $28.31 \mathrm{~b}(12.93 \mathrm{~kg})$ of rinse/serum at the same operating conditions, for $7 \mathrm{hrs}$. The flux varied from 5 to $3 \mathrm{gal} / \mathrm{ft}^{2}$ day ( 8 to $5 \mathrm{~L} / \mathrm{m}^{2} \mathrm{hr}$ ) over this period. overall sugar rejection (by NTSS) was high (60 to 53\%).

The 2000-MW-cutoff membrane was determined to be too tight for the initial ultrafiltration; use of 100,000-MW-cutoff membranes was therefore investigated. 
Permeate Concentration.

Permeate from the initial 2000-MW-cutoff membrane ultrafiltration and two diafiltrations $(40 \mathrm{lb}, 18 \mathrm{~kg})$ was concentrated using rotary evaporators at $104^{\circ} \mathrm{F}, 40^{\circ} \mathrm{C}$ and $27^{\prime \prime} \mathrm{Hg}$ vacuum. The initial NTSS concentration was $1.5 \%$. Twenty-six batches of this were concentrated to produce one solution with a concentration of $8.5 \%$ NTSS which was further concentrated in four batches to a concentration of $58 \%$ NTSS. The fluid color was initially light yellow; final fluid color was dark brown.

100,000-MW-Cutoff Membrane Ultrafiltration. Two types of 100,000-MW-cutoff membranes (GR40PP and PES100) were studied to fractionate the rinse/serum fraction into low-MW and high/intermediate-MW fractions. The higher MW-cutoff membranes were expected to exhibit higher flux and lower sugar rejection during fractionation of the rinse/serum fraction.

The data from four batch separation runs are summarized in Table 19. Unless otherwise indicated, all runs were made at $25^{\circ} \mathrm{C}, 8$ $\mathrm{L} / \mathrm{min}, 100 \mathrm{psi}(0.7 \mathrm{MPa})$ with $0.108 \mathrm{~m}^{2}$ membrane area each of the two membrane types.

Each run (Figs. 17 and 18) started with the initial hour of run time in rerycle mode to monitul the initial fiux. Flux decline was time dependent as well as concentration dependent. After the first run the membranes were rinsed with water.

In the second run temperature scans were run (Table 20) following the initial recycle period $\left(25\right.$ to $\left.64^{\circ} \mathrm{C}\right)$ and the batch separation $\left(25\right.$ to $62^{\circ} \mathrm{C}$ ). At higher temperatures sugar rejection (by NTSS) was lower and the flux significantly higher. The membranes were cleaned with an enzyme detergent (Monarch DDS) following the second run. 
TABLE 19. 100,000-MW-MEMBRANE ULTRAFILTRATION TESTING WITH RINSE/SERUM

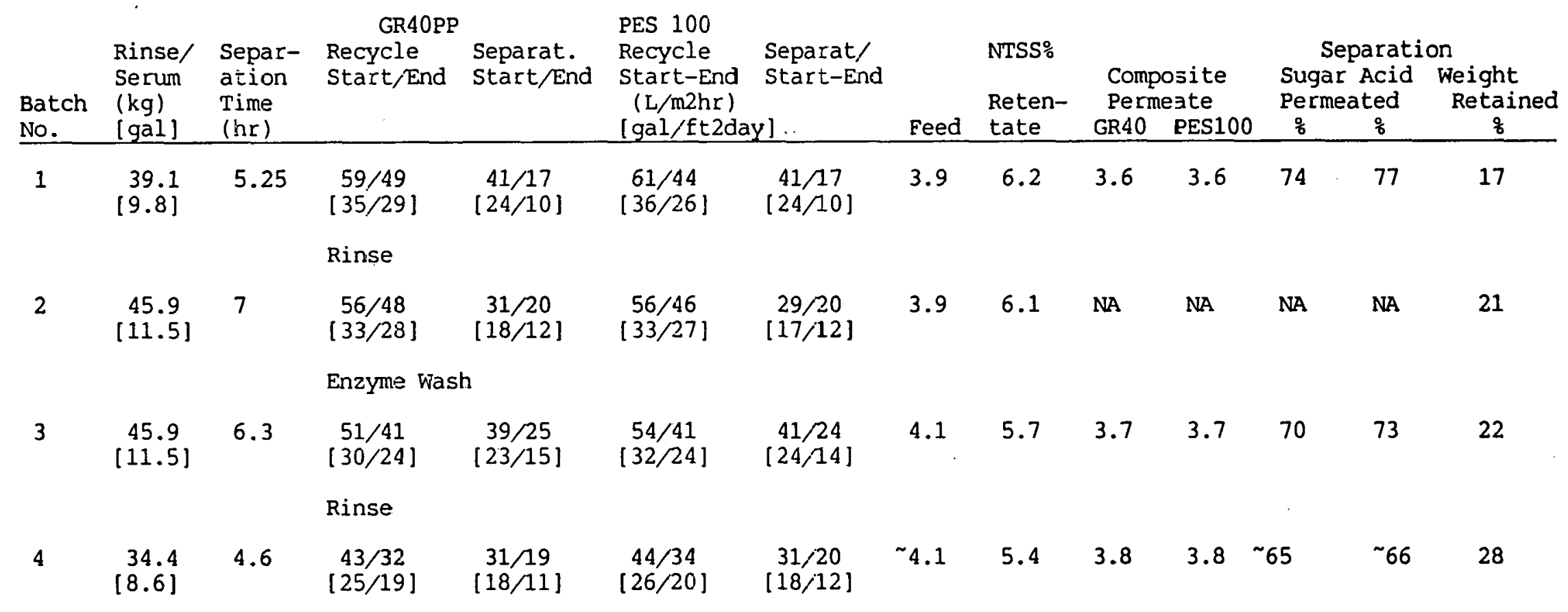




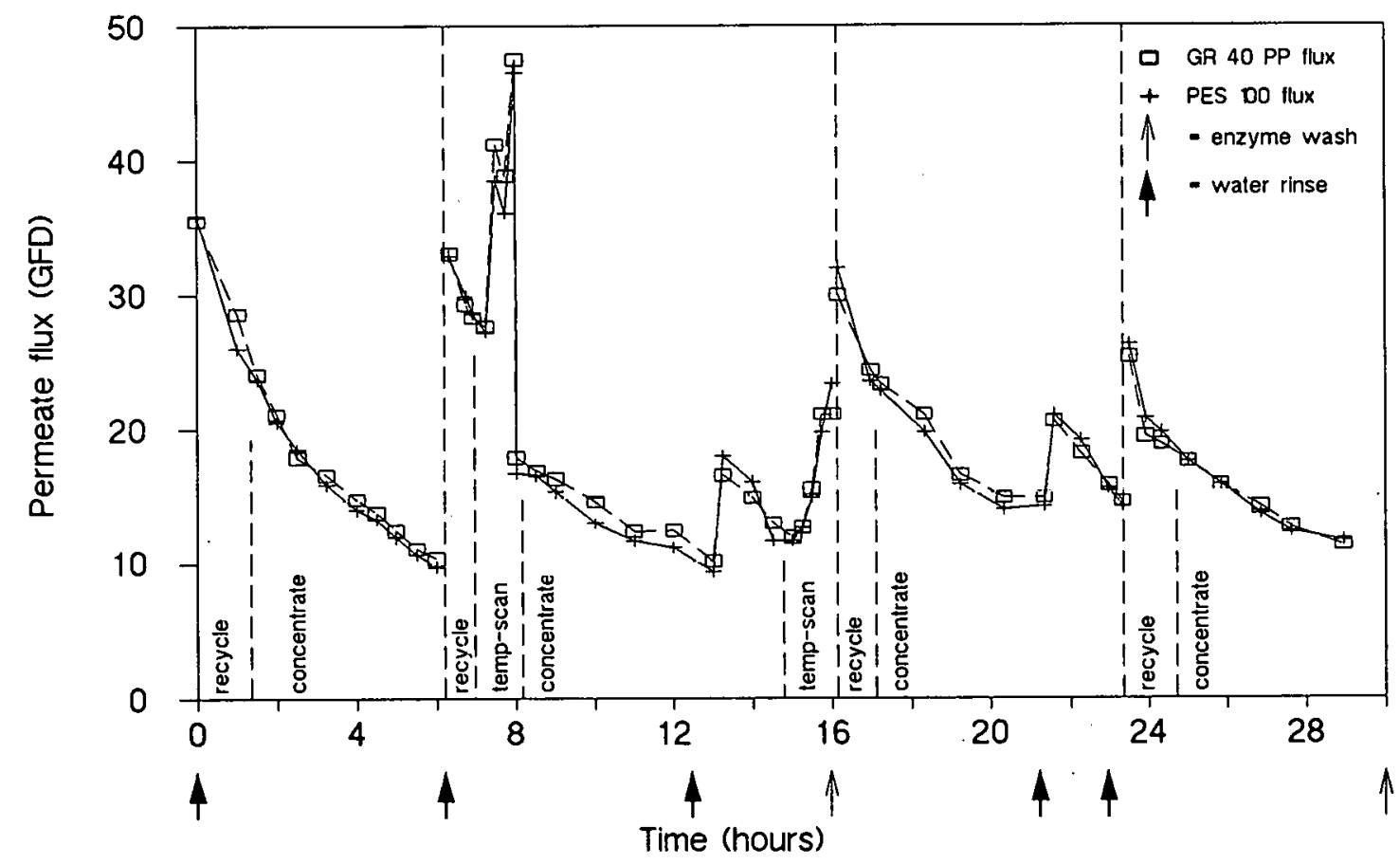

Figure 17 - Flux versus time - 100,000-MW-cutoff membrane ultrafiltration of rinse/serum. 


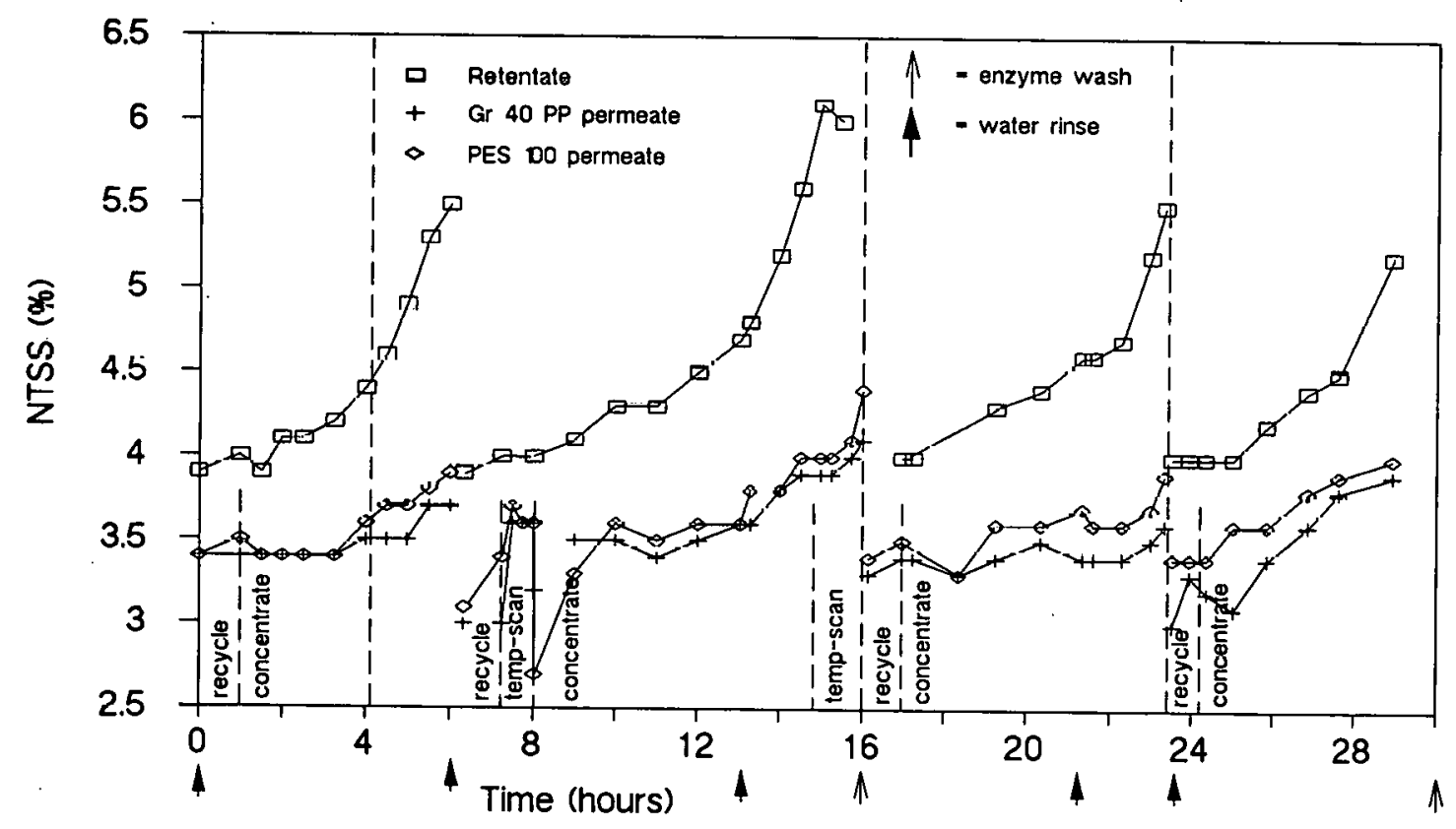

Fiqure 18 - NTSS (q) versus time - 100,000-Mw-cutoff membrane ultrafiltration of rinse/serum. 
TABLE 20. 100,000-MW-CUTTOFF MEIBRANE ULTRAFILTRATION TEMPERATURE SCANS WITH RINSE/SERUM

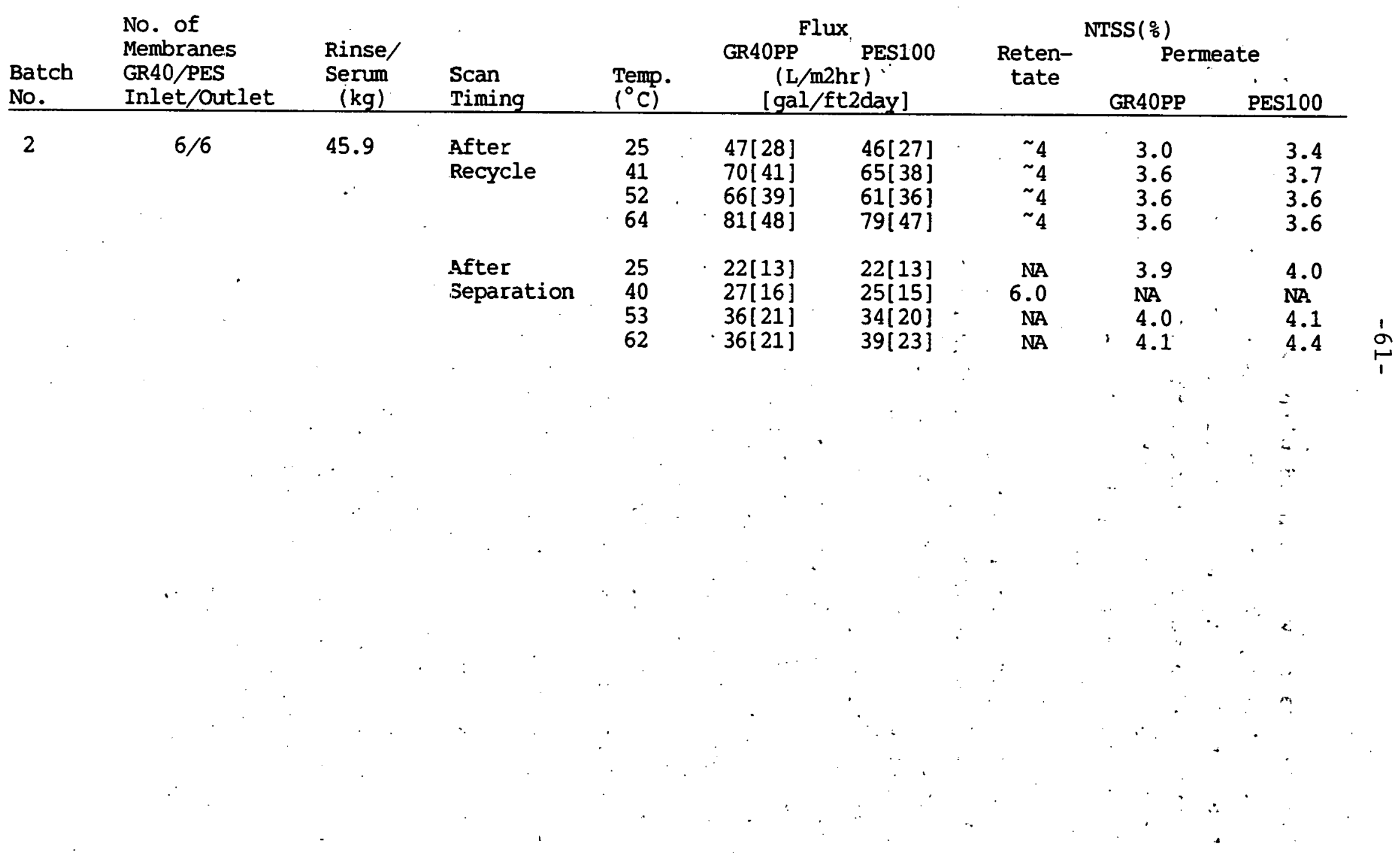


The membranes were rinsed with water between the third and fourth runs. During the five runs, the rinse/serum flux declined during the run. If the membrane run lasted $\sim 6$ to 7 hrs (with rinse/ serum) followed by rinsing with water, the flux of the rinse/ serum returned to almost the original flux (at the beginning of that run). However, after $\sim 16$ hrs operation with rinse/serum, cleaning with a detergent was necessary in order to restore flux.

Flux was significantly higher with the 100,000-MW-cutoff membrane ultrafiltration than with the 2000-MW-cutoff membrane ultrafiltration. Sugar rejection was reduced so that without the use of diafiltration 65-74\% of the sugar permeated. A slightly higher percentage of acid permeated (66-77\%). The final retentate weight was 17-28\% of the initial feed weight. This amount was limited mainly by the pressure drop across the membranes (Fig. 19) and the maximum operating pressure of the PES100 membranes (100 psi; $0.7 \mathrm{MPa})$. The performances of both membranes were similar in flux and rejection, although the pES100 membranes were on the outlet end of the ultrafiltration module and thus experienced lower pressures for most of the testing.

Permeate Concentration.

Permeate from the five batch separations made with the 100,000MW-cutoff membranes $(40.1 \mathrm{~b}, 18 \mathrm{~kg})$ was composited and concentrated using rotary evaporators at $158^{\circ} \mathrm{F}, 70^{\circ} \mathrm{C}$ and $22^{\prime \prime} \mathrm{Hg}$ vacuum. The initial NTSS concentration was $3.5 \%$. Thirty-one batches of this were concentrated to produce one solution with a concentration of $17.6 \%$ NTSS which was further concentrated in six batches to a concentraiton of $76 \%$ NTSS. Total evaporation time was 4-8 hrs. The fluid color was initially light yellow; final fluid color was dark brown. 


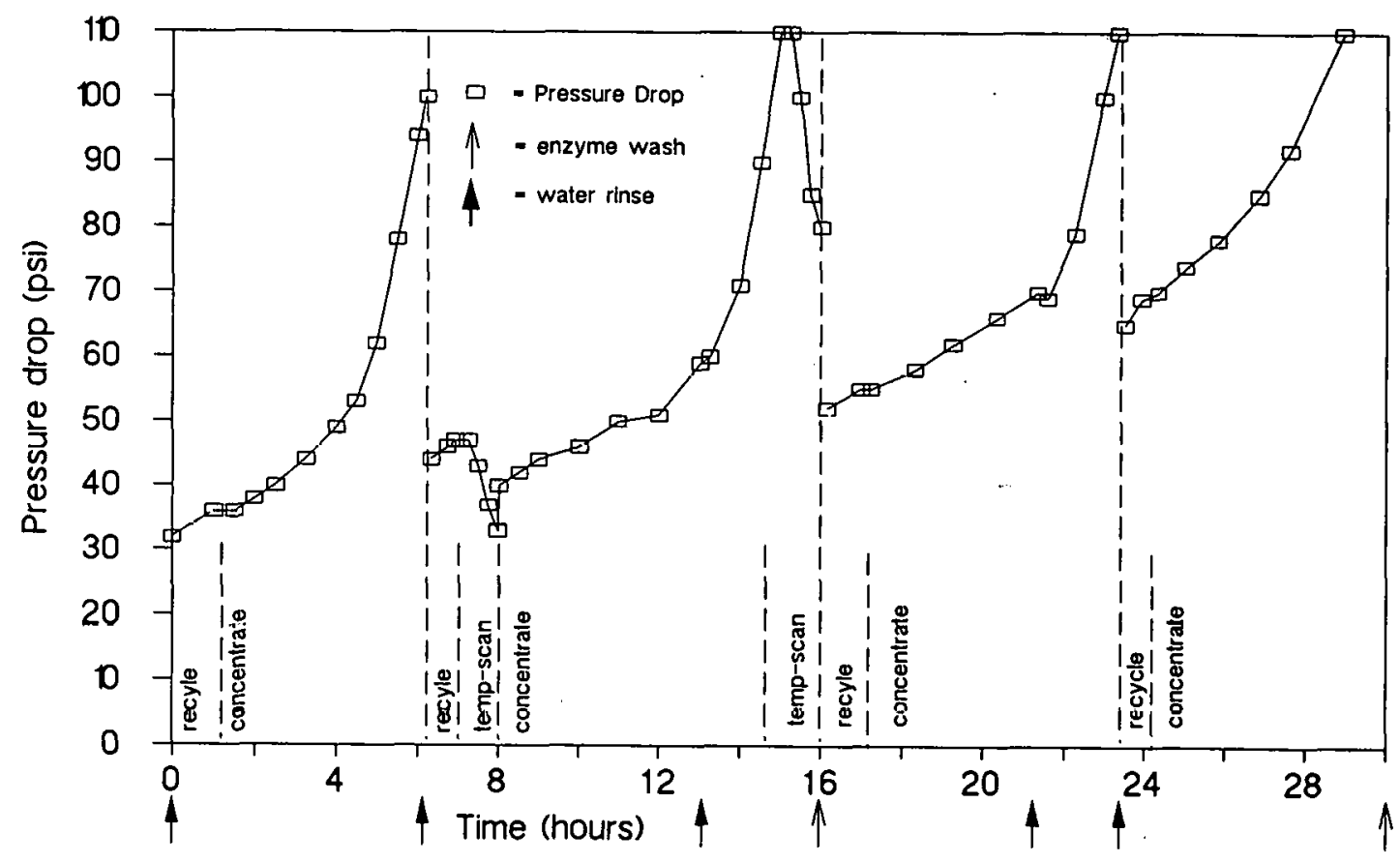

Figure 19 - Pressure drop versus time - 100,000-MW-cutoff membrane ultrafiltration of rinse/serum. 
2000-MW-Cutoff Membrane Ultrafiltration. Once the rinse/serum was fractionated into high- and low/intermediate-MW fractions, ultrafiltration membranes with a 2000-MW-cutoff were used to fractionate the low/intermediate-MW fraction into intermediateand low-MW fractions.

New membranes of the same type used in the "Initial 2000-MW-Cutoff Membrane Ultrafiltration" (GR9OPP) were obtained. The data from three batch separations are summarized in Table 21 . Unless otherwise indicated, all runs were made at $23 \pm 2^{\circ} \mathrm{C}, 8 \mathrm{~L} / \mathrm{min}$ flow rate, $290 \mathrm{psi}$ ( $2 \mathrm{MPa}$ ) with $0.18 \mathrm{~m}^{2}$ total membranc area. The first and third batches consisted of an initial run in batch mode, followed by continuous mode operation. The second batch only ran in batch mode, because the retentate was lost at the end of the run. The membranes were rinsed with water after each of the three batches.

Flux (26-14 L/m $\mathrm{m}^{2} \mathrm{hr}, 16-8 \mathrm{gal} / \mathrm{ft}^{2}$ day) was lower than the flux with $100,000-\mathrm{MW}$-cutoff membranes with rinse/serum $\left(61-17 \mathrm{~L} / \mathrm{m}^{2} \mathrm{hr}, 36-10\right.$ gal/ft ${ }^{2}$ dayl, but higher than the flux with $2000-M W-c u t o f f$ mombranes with rinse/serum $\left(15-5 \mathrm{~L} / \mathrm{m}^{2} \mathrm{hr}, 9-3 \mathrm{gal} / \mathrm{ft}^{2} \mathrm{day}\right)$. $78 \%$ of the sugar (by NTSS) permeated in batches 1 and 3 . The final retentate (intermediate-MW fraction) weight was $\sim 11 \%$ of the initial feed (low/intermediate-MW fraction) weight showing good separation. 
TABLE 21. 2000-MK-CUTOFF MEMBRANE ULTRAFILTRATION TESTING WITH LOW/INT.-MW FRACTION

\begin{tabular}{|c|c|c|c|c|c|c|c|c|c|}
\hline $\begin{array}{l}\text { 3atch } \\
\text { No. }\end{array}$ & $\begin{array}{l}\text { Mode } \\
B / C^{a}\end{array}$ & $\begin{array}{l}\text { Low/Int } \\
\text {-MW } \\
\text { (kg) } \\
\text { [gal] }\end{array}$ & $\begin{array}{l}\text { Recyle } \\
\text { Time } \\
\text { (hr) }\end{array}$ & $\begin{array}{l}\text { Separa- } \\
\text { tion } \\
\text { Time } \\
\text { (hr) }\end{array}$ & $\begin{array}{r}\text { Recycle } \\
\text { Start/End } \\
(\mathrm{L} / \mathrm{m} \\
{[\mathrm{gal} / \mathrm{f}}\end{array}$ & $\begin{array}{l}\text { ux } \\
\text { Separat. } \\
\text { Start/End } \\
\text { hr) } \\
{ }^{2} \text { day] }\end{array}$ & Feed $^{\stackrel{N}{\mathbf{N}}}$ & $\begin{array}{l}\text { SS }(\%) \\
\text { Reten- } \\
\text { tate }\end{array}$ & $\begin{array}{l}\text { Compos- } \\
\text { ite } \\
\text { Permeate } \\
\end{array}$ \\
\hline \multirow[t]{3}{*}{1} & B & $\begin{array}{l}16.8 \\
{[4.2]}\end{array}$ & 1 & 4.1 & $\begin{array}{c}26 / 24 \\
{[16 / 14]}\end{array}$ & $\begin{array}{l}20 / 16 \\
{[12 / 10]}\end{array}$ & 3.5 & 10.1 & 2.7 \\
\hline & $C$ & $\begin{array}{l}16.4 \\
{[4.1]}\end{array}$ & 0.5 & 6.2 & $\begin{array}{c}15 / 18 \\
{[9 / 11]}\end{array}$ & $\begin{array}{c}14 / 17 \\
{[8 / 10]}\end{array}$ & $\begin{array}{l}7.2 \digamma \\
3.6\end{array}$ & 6.6 & 3.6 \\
\hline & & \multicolumn{8}{|c|}{ Rinse } \\
\hline 2 & B & $\begin{array}{l}25.8 \\
{[6.5]}\end{array}$ & 1 & 4.5 & $\begin{array}{l}19 / 19 \\
{[11 / 11]}\end{array}$ & $\begin{array}{c}20 / 14 \\
{[12 / 9]}\end{array}$ & 3.6 & 5.2 & $N A$ \\
\hline \multirow[t]{3}{*}{3} & B & $\begin{array}{l}22.4 \\
{[5.6]}\end{array}$ & 0 & 7.0 & $\begin{array}{c}\text { No Recycle } \\
-\end{array}$ & $\begin{array}{c}15 / 14 \\
{[9 / 8]}\end{array}$ & 3.7 & 7.9 & 2.7 \\
\hline & & \multicolumn{8}{|c|}{ Rinse } \\
\hline & C & $\begin{array}{l}10.5 \\
{[2.6]}\end{array}$ & 0 & 6.1 & No Recycle & {$\left[\begin{array}{r}11 / 9 \\
6 / 5]\end{array}\right]$} & $\begin{array}{l}7.8 / \\
3.6\end{array}$ & 7.6 & 3.7 \\
\hline
\end{tabular}

\footnotetext{
${ }^{\mathbf{a}} \mathrm{B}=$ Batch

$\mathrm{C}=$ Continuous
}

${ }^{b}$ Continuous mode feed consisted of retentate from batch mode plus Low/Int-MW fraction.

'Batch No. 1 continuous mode feed (retentate from batch mode) was diluted with additional Low/Int-MW fraction. 


\section{Ion Exchange studies}

The low MW- fraction was available for fractionation by ion exchange into sugars and organic acids. The purpose was to examine whether certain components (possibly sugars and/or organic acids) might be eliminated at the tomato processing plant, thus saving on containerization and transportation costs. These component(s) could then be obtained from local sources and added back at the point of remanufacture.

Initial Anion Resin Testing. Initially, the anion resins were studied with a model fluid. The testing with the model fluid and with the low-MW fraction involved the sequence of procedures below:

Feed Cycle - Feed entered at the top of the resin bed and passed downflow through the column exiting at the bottom. Flow rate was 20-25 ml/min. Column effluent was measured periodically for $\mathrm{pH}$, conductivity, fructose and acidity. The feed cycle was terminated when citric acid content exceeded $0.2 \%$.

Sweeten-off Backwash - Water (250ml) entered at the bottom of the resin bed and passed upflow through the column exiting at the top. This proceudre was followed to purge the column of the feed solution.

Regeneration - Sodium hydroxide ( $4 \%$ ) solution (150 ml) entered at the top of the resin bed and passed downflow through the column with a 45 min contact time exiting at the bottom. The effluent was called $\mathrm{NaOH}$ regenerant.

NaOH-off Backwash - water (600ml) entered at the bottom of the resin bed and passed upflow through the column exiting at the top. 
Final Rinse - water entered at the top of the resin bed and passed downflow through the column until the $\mathrm{pH}$ of the effluent was less than 8.3. (An exception was made with the sM-73 resin. Rinsing was so slow that the final rinse was discontinued after several liters of water had passed through; the $\mathrm{pH}$ was $\sim 10$. )

A model system fluid ( $4 \%$ fructose [by NTSS], $0.4 \%$ citric acid [by titratable acidity], $\mathrm{pH} 2.5$, conductivity $=1100 \mathrm{us} / \mathrm{cm}$ ) was used as feed for testing. Two weak base anion resins (IWT $S M-73$ and A-399b) were used. Each column had $100 \mathrm{ml}$ bed volume.

The two resins successfully removed citric acid from the model fluid (as measured by titratable acidity). The apparent capacity of the resins (in gm anhydrous citric acid removed from the feed per $100 \mathrm{ml}$ bed volume, calculated from the volume of feed solution treated before the effluent reached $0.025 \%$ citric acid) is below:

\begin{tabular}{lllc} 
Run & $\begin{array}{l}\text { Flow } \\
\text { No. }\end{array}$ & $\begin{array}{l}\text { Apparent Capacity } \\
(\mathrm{m} 1 / \mathrm{min})\end{array}$ & $\begin{array}{l}\text { (gm citric acid removed/ } \\
\text { bed volume }[100 \mathrm{ml}])\end{array}$ \\
\hline & & & A-399b \\
& 20 & 6.5 & $\mathrm{NA}$ \\
2 & 24 & 4.8 & 10.3 \\
3 & 20 & 5.9 & 11.8
\end{tabular}

The A-399b resin had about twice the capacity of the SM-73 resin. 
Separation of Low-MW Fraction. The feed for this testing was the low-MW fraction ( $3.2 \%$ NTSS, $0.223 \%$ anhydrous citric acid, pH $\sim 4.1$, conductivity $=3650 \mathrm{us} / \mathrm{cm}) . \mathrm{SM}-73$ and $\mathrm{A}-399 \mathrm{~b}$ were used. Each column had $100 \mathrm{ml}$ bed volume.

Both resins removed organic acids from the low-MW fraction (as measured by titratable acidity). The apparent capacity of the resins calculated from the volume of feed solution treated before the effluent reached 0.03 to $0.04 \%$ citric acid) is below:

$\begin{array}{llc}\text { Flow } & \begin{array}{c}\text { Apparent capacity } \\ \text { Resins }\end{array} & \begin{array}{l}\text { (gm citric acid removed/ } \\ \text { bed volume [100ml]) }\end{array} \\ \text { SM-73 } & 18 \pm 13 & \sim 7.5 \\ \text { A-399b } & 18 \pm 9 & \sim 6.6\end{array}$

The SM-73 resin's capacity with the low-MW fraction was similar to that with the model system fluid. The conductivity of the low-MW fraction was three times as high as the conductivity of the model system fluid.

The A-399b resin's capacity with the low-MW fraction was lower than with the model system fluid. This resin permanently took on a yellow/grey color from the feed.

The citric acid was left in salt form, having been removed by the NaOH. These organic acid salts were then converted to organic acids by use of a cation resin. 
Initial Cation Resin Testing. A model fluid was used for initial testing of the strong acid cation exchange resin (IWT C-391b). A formula for the model fluid was calculated from the theoretical concentration of sodium citrate in the $\mathrm{NaOH}$ regenerant produced with $0.22 \%$ anhydrous citric acid in the feed (low-Mw fraction) to the anion resin; and the theoretical concentration of $\mathrm{NaOH}$ in the $\mathrm{NaOH}$ regenerant based upon that fluid's $\mathrm{pH}$. This resulted in a model fluid of $6 \%$ sodium citrate and $0.4 \% \mathrm{NaOH}$. The $\mathrm{pH}$ of this solution was $\sim 12.6$, conductivity $\sim 40,000 \mathrm{us} / \mathrm{cm}$. The column had a bed volume of $100 \mathrm{ml}$. The testing with the model fluid and with the NaOH regenerant (from the anion exchange of the low-MW fraction) involved the sequence of procedures below:

Feed Cycle - This procedure was the same as in anion resin testing. Column effluent was measured periodically for $\mathrm{pH}$, conductivity, acidity. The feed cycle was terminated when $\mathrm{pH}$ reached 12 .

Sweeten-off Backwash - See anion resin testing procedure.

Regeneration - Hydrochloric acid ( $7 \%$ ). solution ( $150 \mathrm{ml}$ ) entered at the top of the resin bed and passed downflow through the column with a $30 \mathrm{~min}$. contact time.

HCl-off Backwash - This procedure was the same as the NaOH-off Backwash in anion resin testing.

Final Rinse - This procedure was the same as in anion resin. testing. The rinsing was discontinued when the $\mathrm{pH}$ of the effluent was greater than or equal to 4.3 .

The resin was effective in converting the sodium citrate to citric acid. The apparent capacity of the resin is below (defined as the gm citric acid produced per $100 \mathrm{ml}$ bed volume; 
calculated from the volume of feed solution treated before the effluent dropped below $0.1 \%$ anhydrous citric acid):

\section{Apparent Capacity}

Flow (gm citric acid produced/

$\begin{array}{ccr}\text { Run No. } & \frac{(\mathrm{ml} / \mathrm{min})}{} & \text { bed volume } \\ 1 & 24 & \sim 4.5 \\ 2 & 20 & \sim 3.8\end{array}$

There appeared to be a decrease in capacity from the first run to the second.

Conversion of Organic Acid Salts to Acids. The first feed was the NaOH regenerant from the anion exchange of the low-MW fraction with the $\mathrm{A}-399 \mathrm{~b}$ resin $(\mathrm{pH} \sim 12.6$, conductivity $=52,500$ us $/ \mathrm{cm}, \sim 300 \mathrm{gm})$. " $\mathrm{pH}$ and acidity of the effluent were monitored (Figure 20 and Table 22 ). The column was regenerated.

The next feed run through the column was the sweeten-off Backwash from the above cation exchange. In addition effluent with $\mathrm{pH} \geq 2$, from the above cation exchange, was added as feed. When this feed source was depleted, the column flow was stopped and the $\mathrm{NaOH}-$ off Backwash from the A-399b resin ( $670 \mathrm{ml})$ was added as. feed. $\mathrm{pH}$ and acidity of lie effluant were monitored (Figure 21 and Table 22). The column was regenerated.

Part of the Final Rinse ( $\sim 50 \mathrm{ml})$ from the $A-399 \mathrm{~b}$ anion resin was then used as feed. $\sim 200 \mathrm{ml}$ water was added to wash out all the feed. The $\mathrm{pH}$ of the effluent ranged from 2.8 to 4.65 ; acidity ranged from 0.014 to $0.001 \%$ anhydrous citric acid. This (Final Rinse) effluent did not contribute significantly to the totality of organic acids. 
The above procedure was repeated using the solutions produced from the anion exchange of the low-MW fraction with the SM-73 resin. pHi and acidity of the effluent were monitored (Figs 22 and 23 and Table 22).

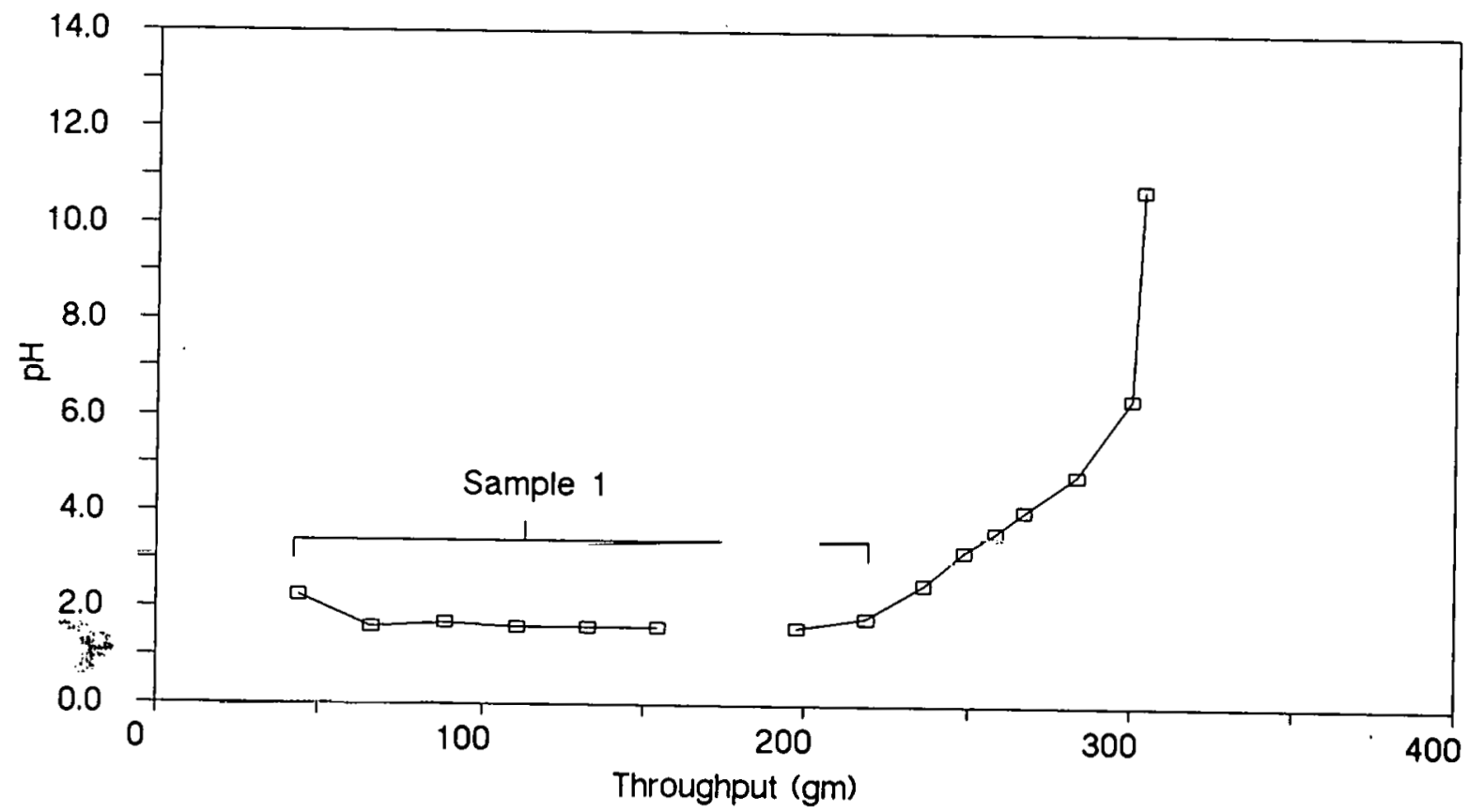

Figure 20 - pH vs. throughput for cation resin C-391b using $\mathrm{NaOH}$ regenerant from anion resin $\mathrm{A}-399 \mathrm{~b}$ as feed. 


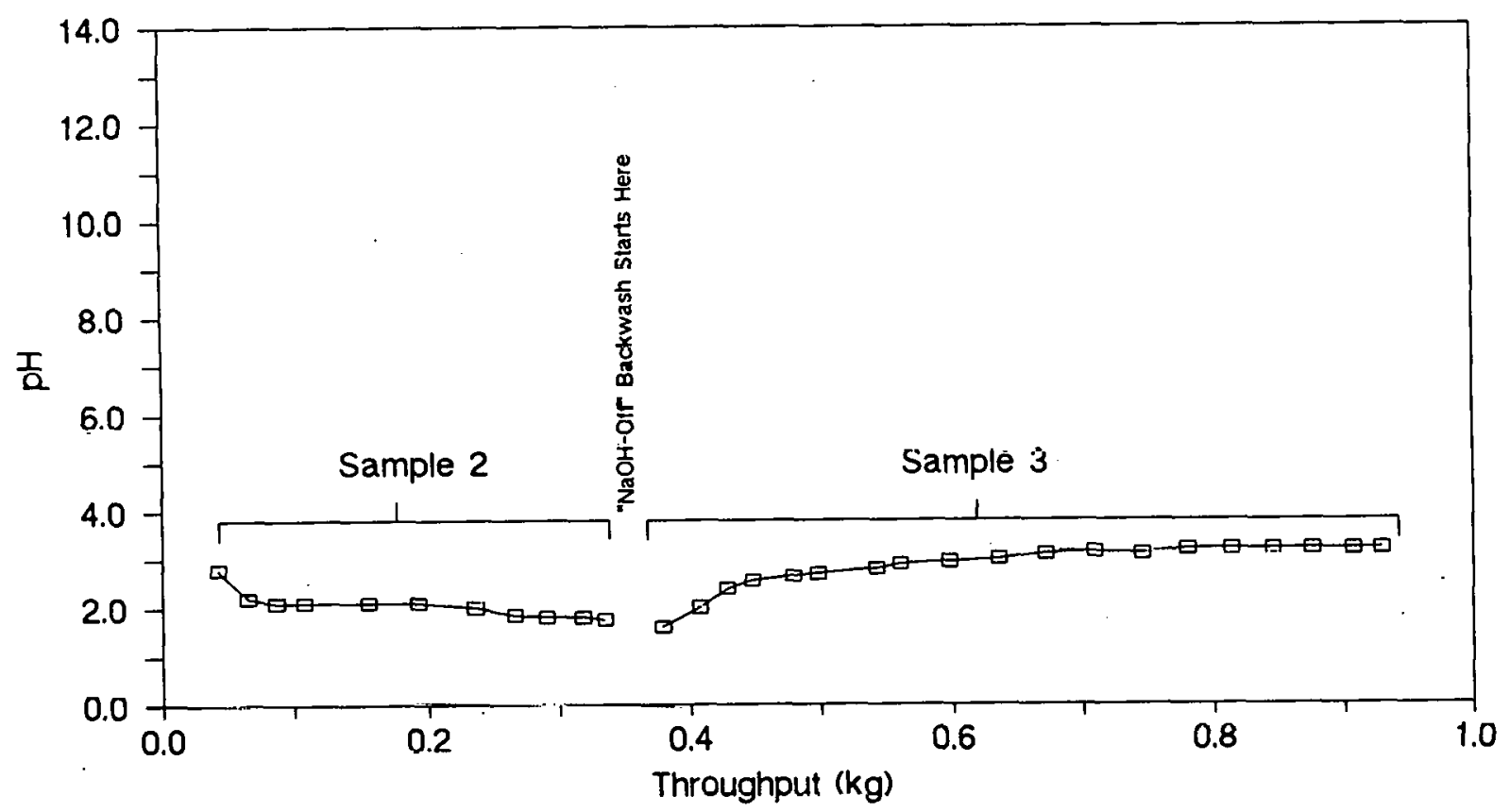

Figure 21 - pH vs. throughput for cation resin C-391b using effluent $\geq \mathrm{pH} 2$ (from Figure 20) plus Sweeten-off Backwash of resin in Figure 20; second feed is NaOH-off Backwash from anion resin. A-399b. 

TABLE 22. ACIDITY OF EFFLUENTS FROM CATION EXCHANGE WITH
IWT C-391b OF ORGANIC ACID SALTS SAMPLES

\begin{tabular}{|c|c|c|c|c|c|}
\hline $\begin{array}{l}\text { Sample } \\
\text { No. }\end{array}$ & $\begin{array}{l}\text { Feed } \\
\text { I.D. }\end{array}$ & $\begin{array}{l}\text { Origin } \\
\text { (Anion } \\
\text { Exchange } \\
\text { Resin) } \\
\end{array}$ & $\begin{array}{l}\text { Anhydrous } \\
\text { Citric } \\
\text { Acid } \\
(q)\end{array}$ & $\mathrm{pH}$ & $\begin{array}{c}\text { Quantity } \\
(\mathrm{gm})\end{array}$ \\
\hline 1 & $\begin{array}{c}\text { NaOH } \\
\text { Regenerant }\end{array}$ & $A-399 b$ & 1.21 & 1.6 & 220 \\
\hline 2 & $\begin{array}{l}\text { NaOH Regen. } \\
\text { Effluent >pH } 2 \\
+ \text { Sweeten-off } \\
\text { from Sample } 1\end{array}$ & $A-399 b$ & 0.46 & 1.9 & 335 \\
\hline 3 & $\begin{array}{l}\text { NaOH-off } \\
\text { Backwash }\end{array}$ & $A-399 b$ & 0.11 & 2.3 & 600 \\
\hline 5 & $\begin{array}{c}\mathrm{NaOH} \\
\text { Regenerant }\end{array}$ & $S M-73$ & 0.94 & 1.45 & 290 \\
\hline 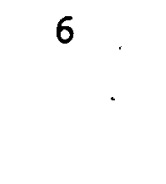 & $\begin{array}{l}\text { NaOH Regen. } \\
\text { Effluent >pH } 2 \\
+ \text { Sweeten-off } \\
\text { from Sample } 5\end{array}$ & $S M-73$ & 0.37 & 1.7 & 320 \\
\hline 7 & $\begin{array}{l}\text { NaOH-off } \\
\text { Backwash }\end{array}$ & $S M-73$ & 0.19 & 2.35 & 670 \\
\hline
\end{tabular}




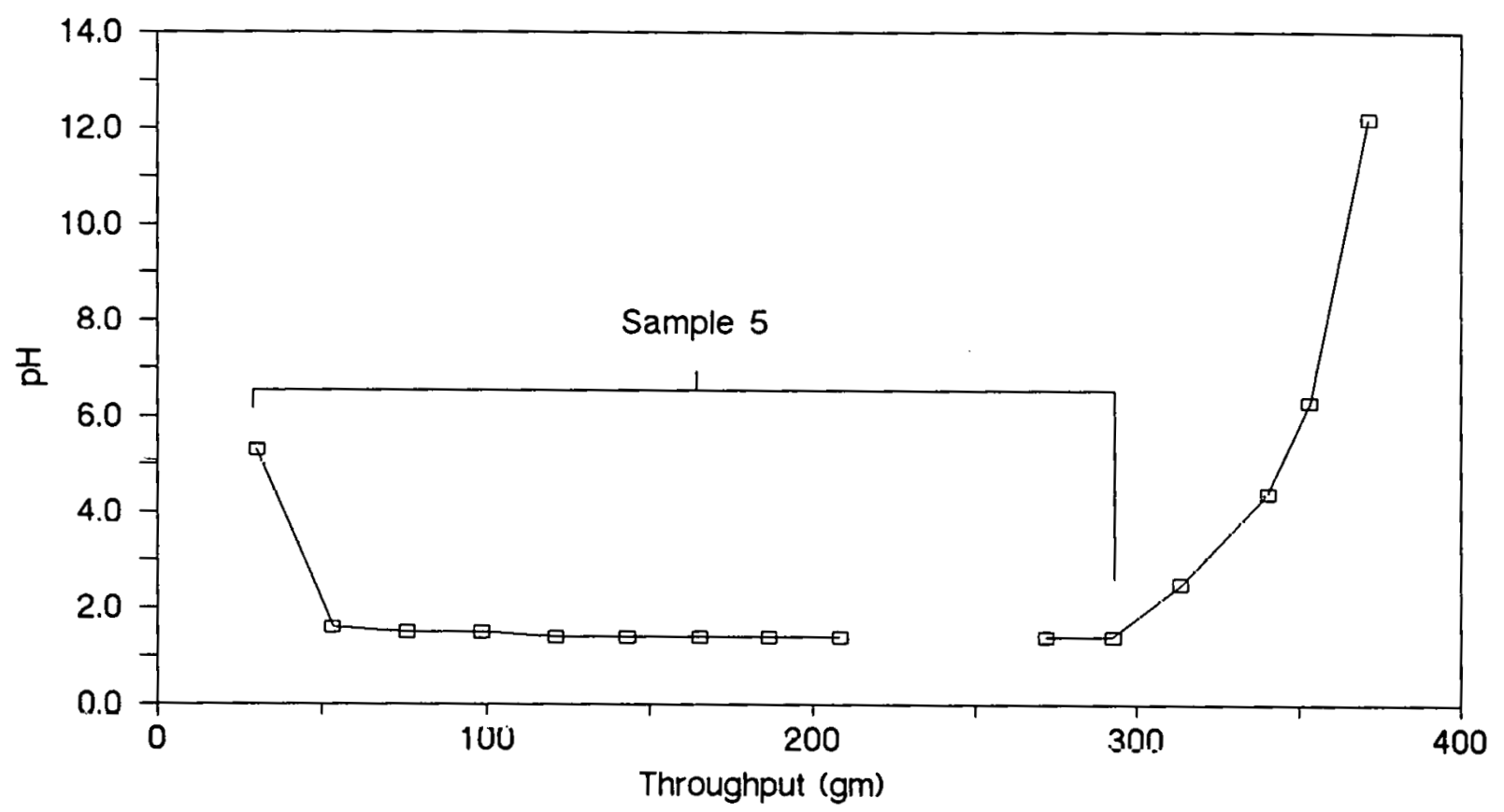

Figure 22 - pH vs. throughput for cation resin C-391b using $\mathrm{NaOH}$ regenerant from anion resin $S M-73$ as feed.

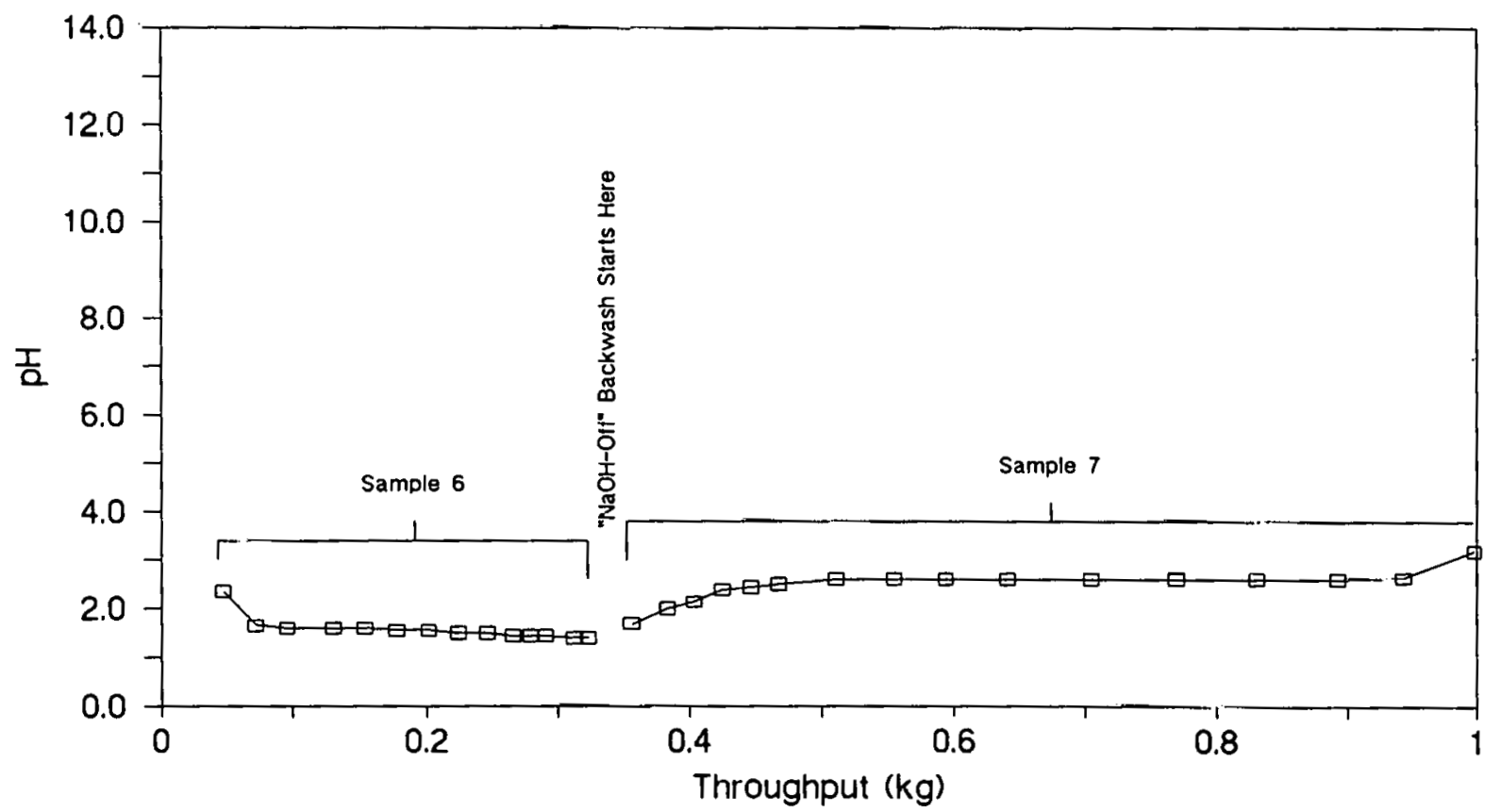

Figure 23 - pH vs. throughput for cation resin C-391b using effluent $>\mathrm{pH} 2$ (in Figure 22) plus sweeten-off Backwash of resin in Figure 22; second feed is NaOH-off Backwash from anion resin SM-73. 
Because some of the effluent was sent back through the column during the runs, the determination of the resin's apparent capacity was obscured. Approximations are made below:

\section{Feed}

Solutions

From

$$
A-399 b
$$

SM-73
Flow

$\underline{(\mathrm{ml} / \mathrm{min})}$
Apparent Capacity (gm citric acid produced/ bed volume $[100 \mathrm{ml}])$

These capacities were lower than with the model system, but the capacity did not decrease significantly from the first run to the second run.

\section{Mass Balance}

An attempt has been made to calculate the mass balance of the above separation and ultrafiltration studies. Table 23 summarizes these calculations. As can be seen, after the first ultrafiltration step $(100,000-M W$ cutoff $)$, all of the total solids, sugars, and organic acids from the rinse/serum $( \pm 2.6 \%)$ were recovered. After the second ultrafiltration step $(2000-\mathrm{MW}$ cutoff), 95-98\% of the total solids and sugars, and $87 \%$ of the organic acids of the rinse/serum were recovered. 
TABLE 23. MASS BALANCE

\begin{tabular}{|c|c|c|c|c|c|c|c|c|}
\hline Fraction & $\begin{array}{c}\text { Weight } \\
\mathrm{gm}\end{array}$ & $\begin{array}{l}\text { TS } \\
\% \\
\end{array}$ & $\begin{array}{c}\text { Sugar. } \\
\frac{\circ}{6}\end{array}$ & $\begin{array}{c}\text { Acid } \\
\div \\
\end{array}$ & $\begin{array}{l}\text { TS } \\
\text { gm }\end{array}$ & $\begin{array}{c}\text { Sugar } \\
\text { gm }\end{array}$ & $\begin{array}{c}\text { Acid } \\
\text { gm }\end{array}$ & $\begin{array}{c}\text { TS } \text { Mugar Acid }^{\text {Mass Balance }} \\
\end{array}$ \\
\hline $\begin{array}{l}\text { Puree } \\
\text { Water }\end{array}$ & $\begin{array}{l}400 \\
600 \\
\end{array}$ & $\begin{array}{r}10.7 \\
0 \\
\end{array}$ & $\begin{array}{r}\text { NA } \\
0 \\
\end{array}$ & $\begin{array}{r}1.13 \\
0 \\
\end{array}$ & $\begin{array}{r}42.80 \\
0 \\
\end{array}$ & $\begin{array}{r}N A \\
0 \\
\end{array}$ & $\begin{array}{r}4.52 \\
0 \\
\end{array}$ & $100 \underbrace{\text { ( } s \text { of Puree) }}_{\mathrm{NA}} 100$ \\
\hline $\begin{array}{l}\text { Rinsed-Pulp } \\
\text { Rinse/Serum }\end{array}$ & $\begin{array}{r}62 \\
938\end{array}$ & $\begin{array}{r}12.5 \\
3.9\end{array}$ & $\begin{array}{c}\mathrm{NA} \\
2.43\end{array}$ & $\begin{array}{l}0.18 \\
0.53\end{array}$ & $\begin{array}{r}7.75 \\
36.58\end{array}$ & $\begin{array}{l}\mathrm{NA} \\
22.79\end{array}$ & $\begin{array}{l}0.11 \\
4.97\end{array}$ & . \\
\hline $\begin{array}{l}\text { SubTotal } \\
\quad \text { (Rinsed-Pu }\end{array}$ & $\begin{array}{l}1000 \\
\text { ulp }+ \text { Rin }\end{array}$ & se/Serum & & & 44.33 & NA & 5.08 & $10 \equiv .5^{\left(\frac{\circ}{8} \text { of Puree) }\right.} \mathrm{NA} 112.4$ \\
\hline $\begin{array}{l}\text { High-MW } \\
\text { Low/Int-MW }\end{array}$ & $\begin{array}{l}203.6 \\
734.4\end{array}$ & $\begin{array}{l}5.6 \\
3.5\end{array}$ & $\begin{array}{l}2.52 \\
2.4\end{array}$ & $\begin{array}{l}0.61 \\
0.49\end{array}$ & $\begin{array}{l}11.40 \\
25.70\end{array}$ & $\begin{array}{r}5.13 \\
17.63\end{array}$ & $\begin{array}{l}1.24 \\
3.60\end{array}$ & \\
\hline $\begin{array}{l}\text { SubTotal } \\
\quad \text { (Rinsed-Pu. } \\
\text { SubTotal } \\
\quad \text { (High-MW + } \\
\end{array}$ & $\begin{array}{r}1000 \\
\text { ulp }+ \text { Higl } \\
938 \\
+ \text { Low/Int } \\
\end{array}$ & $\begin{array}{l}(\mathrm{L}-\mathrm{MW} \div \mathrm{L} \\
-\mathrm{MWN}) \\
\end{array}$ & Low/Int-l(W) & & $\begin{array}{l}44.86 \\
37.11\end{array}$ & $\begin{array}{c}\text { NA } \\
22.76\end{array}$ & $\begin{array}{l}4.95 \\
4.84\end{array}$ & 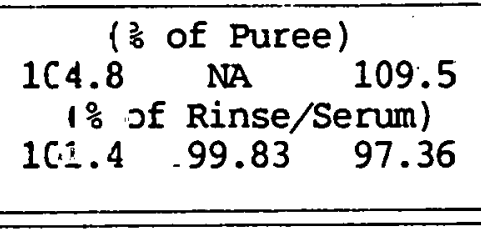 \\
\hline $\begin{array}{l}\text { Int-MN } \\
\text { Low-MN }\end{array}$ & $\begin{array}{r}97.9 \\
636.5\end{array}$ & $\begin{array}{l}6.7 \\
2.8\end{array}$ & $\begin{array}{l}1.21 \\
1.95\end{array}$ & $\begin{array}{l}0.85 \\
0.36\end{array}$ & $\begin{array}{r}6.58 \\
17.82\end{array}$ & $\begin{array}{r}4.12 \\
12.41\end{array}$ & $\begin{array}{l}0.83 \\
2.29\end{array}$ & \\
\hline \multicolumn{5}{|c|}{$\begin{array}{l}\text { SubTotal } 1000 \\
\quad \text { (Rinsed-Pulp - High-MW + Int-MW + Low-MW) } \\
\text { SubTotal } 938 \\
\quad \text { (High-MW + Int-MW + Low-MW) } \\
\text { Subtotal } \quad 734.4 \\
\quad \text { (Int-MW + Low-MW) }\end{array}$} & $\begin{array}{l}35.78 \\
24.38\end{array}$ & $\begin{array}{l}21.66 \\
16.53\end{array}$ & $\begin{array}{l}4.365 \\
3.123\end{array}$ & $\begin{array}{c}\text { (\% of Puree) } \\
101.7 \text { NA } 99.05 \\
\vdots \% \text { of Rinse/Serum) } \\
97.81 \text { 95.04 } 87.81 \\
\vdots \% \text { of } \text { Low/Int-MW) } \\
94.85 \quad 93.80 \quad 86.79\end{array}$ \\
\hline
\end{tabular}




\section{Recombination studies}

After separating and fractionating the puree into fractions, reconstitution of these fractions was performed.

Second Level Recombination. Rinsed-pulp, high-MW, and concentrated low/intermediate-MW fractions were combined to make recombined puree. Using weights of fractions obtained during the separation/fractionation steps and the amount of solids in the original puree and fractions, calculations were made of how much of each fraction to add to make the puree. Since there had been spills during the initial centrifugation, exact tracking of fractions was not possible. Three preliminary trials were made homogenizing Trials 1 and 3 for $7 \mathrm{~min}$, Trial 2 for $3 \mathrm{~min}$. The samples were checked for solids and the final trial was tested for Bostwick, color, and syneresis. Results are summarized in Table 24. The amount of insoluble solids is apparently critical to viscosity. The three trials showed progressively better viscosity results and solids closer to the original solids level. The Bostwick results appeared promising. The color of the recombined product was lighter (higher $L^{*}$ ), with slightly less red/purple (lower $a *$ ), and more yellow (higher b*). Syneresis results were similar to the original puree.

A second set of triale was made. A small amount of pulp $10.5 \%$ of the rinse/serum) which had been strained by cheese cloth from the rinse/serum prior to ultrafiltration was also added to the three fractions. All samples were homogenized $7 \mathrm{~min}$. 
TABLE 24. RESULTS OF RECONBINATIONS

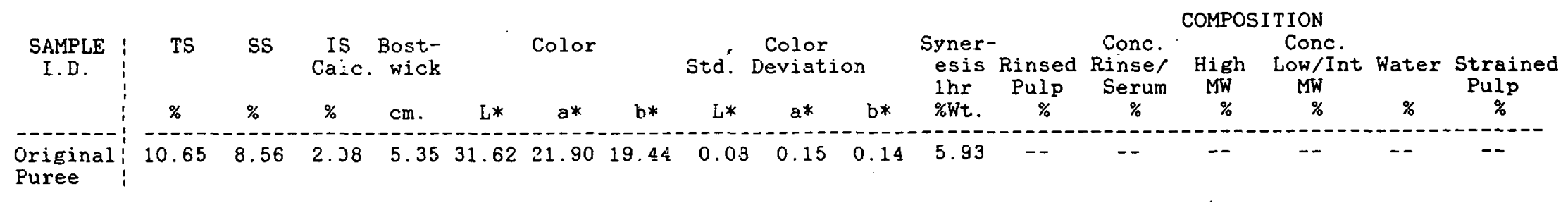

Recombined Purəe from Rinsed-PulF, High-MW, and Low/Int:-MW Fractions (Second Level Recombination)

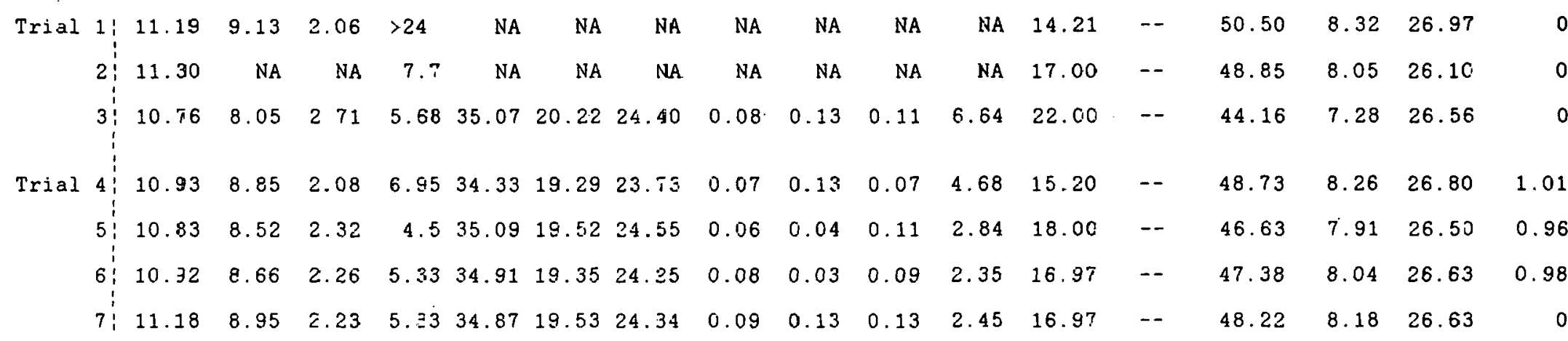

Recombined Puree from Rinsed-Pulp and Concentrated Rinse/Serum (First Level Recombination)

$\begin{array}{lllllllllllllllllll}\text { Trial } & 1 & 10.91 & 8.81 & 2.10 & 6.72 & 35.10 & 19.34 & 24.57 & 0.04 & 0.07 & 0.04 & 4.19 & 15.90 & 68.20 & -- & -- & -1 & \end{array}$ $\begin{array}{lllllllllllllllllllll}2 & 10.87 & 3.57 & 2.30 & 5.45 & 35.69 & 19.45 & 25.15 & 0.14 & 0.12 & 0.13 & 3.2 & 18.00 & 66.00 & \ldots & -1\end{array}$ \begin{tabular}{l|lllllllllllllllllll}
3 & 10.85 & 8.60 & 2.25 & 4.3 & 35.92 & 19.42 & 25.46 & 0.17 & 0.15 & 0.10 & NA & 18.94 & 65.00 & $\ldots$ & $\ldots$
\end{tabular} 
The results of these trials (Trials 4-7) are summarized in Table 24. The solids levels were similar to the original puree. The Bostwick viscosity results were good. The color results were similar to Trial 3 with slightly less red/purple. syneresis results were better than with the original puree.

Thus, these trials showed that duplicating the solids of the original puree was difficult. Insoluble solids content is critical to the viscosity. Viscosity was better in the recombined puree than in the original puree, but insoluble solids were slightly higher than the original. If the solids could be exactly duplicated, firmer conclusions could be drawn.

First Level Recombination. Some rinse/serum was concentrated by rotary evaporation $(2-2.5 \mathrm{hrs})$ at $45-50^{\circ} \mathrm{C}, 26-27^{\prime \prime}$ Hg vacuum to 12.8\% TS. This concentrated rinse/serum was combined with rinsed-pulp to make recombined puree. Three trials were made, homogenizing all samples for $7 \mathrm{~min}$.

Results are summarized in Table 24. The solids levels and Bostwicks obtained are similar to Trials 4-7 of the Second Level Recombination (also in Table 24). The color is slightly lighter with slightly more yellow than Trials 4-7 of the second Level Recombination. Syneresis results were better than the original puree. These trials showed similar results to the above second Level Recombination trials.

\section{Pulp Drying studies}

Drying of the rinsed pulp would greatly facilitate its handing, storage, and transporlation. To study this, tomato pulp was drum dried and evaluated for hygroscopy. 
Drying of Rinsed Pulp. A twin drum laboratory dryer (Blau-Knox Co., Buflovak Equipment Div., Model ALC4) was used. This dryer had two drums, each $6 \mathrm{in.}$ in diameter and 8 in. in length. The drums were driven by a Graham transmission model 175BR5. The dryer drums were heated internally by saturated steam; steam pressure determined drying temperature. Drum rotational speed determined product drying time, and the nip setting determined the product film thickness on the drycr:

Seven drying trials were conducted. The first was a preliminary evaluatiun trial. In this trial, it was decided that in order to obtain a feed consistency which could film on the dryer's surface, a slurry of rinsed-pulp and water was required. In the subsequent. four trials, the amount of water added to rinsed-pulp was varied, and dryer settings were also varied, to obtain different dried pulps. The dried pulps were evaluated later by their ability to resist fungal spoilage in storage. The results are given in Table 25. The last two drying trials used unrinsed puree ( $9.6 \%$ NTSS) and a combination of tomato puree and paste which had an $18.6 \%$ NTSS, to provide a dried tomato product which could be used as a suyar-containing control. This was. compared with the dried rinsed-pulp, which contained little sugar. Results for these two trials are also given in Table 25 .

Results in Table 25. show that the dryer was successful in producing a dried rinsed-pulp of $6 \%$ moisture content. The dried rinsed-pulp was orange in color, and resembled flakes of bran. Tomato puree could not be dried on the dryer., due to its low solids content, which caused the stlcky product to roll up at the cut-off knives. The puree/paste blend was successfully dried to $4 \%$ moisture content; it was red in color. 
TABLE 25. PULP DRYING RESULTS

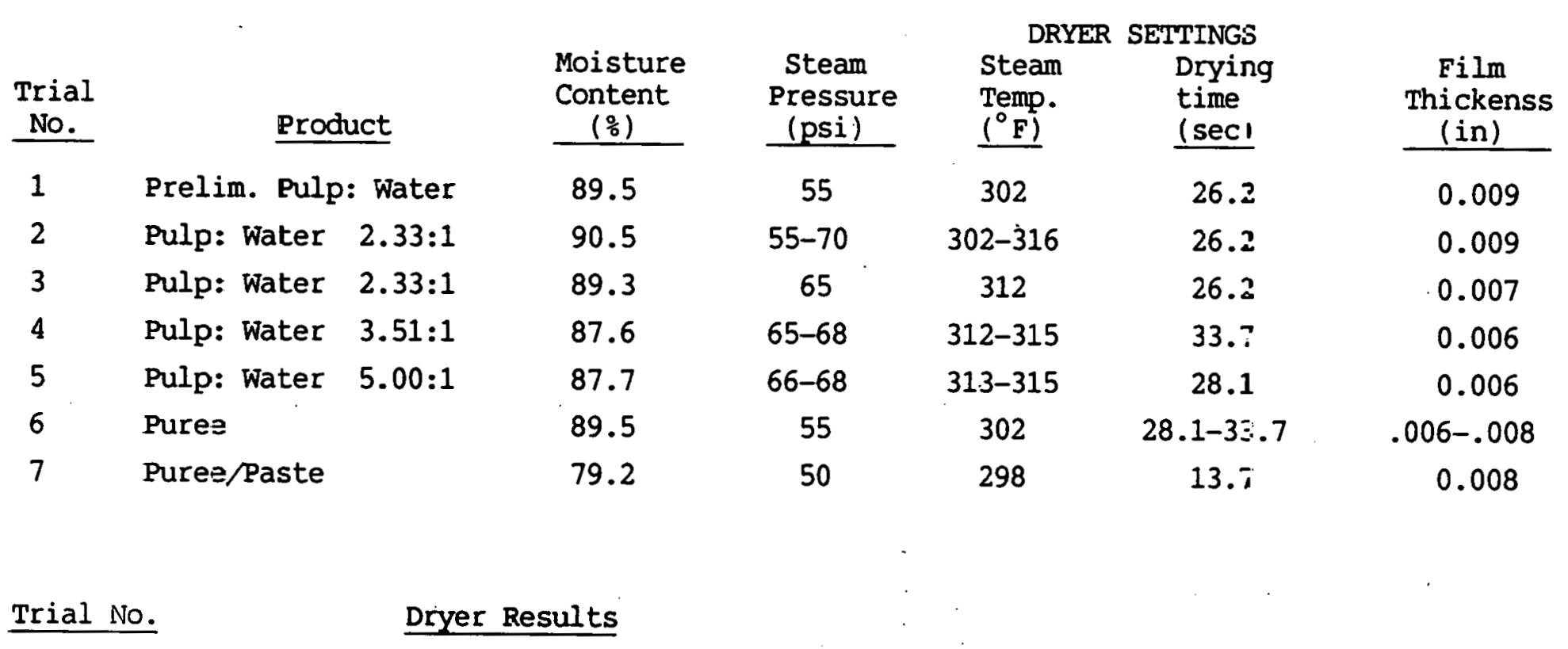

Not dried sufficiently to avoid fungal spoilage

Dried well, no spoilage

Not dried sufficiently to avoid fungal spoilage

Dried well, no spoilage, moisture content: $6 \%$

Dried well, no spoilage

Wouldn't dry, very sticky, rolled up at cut-off knives

Ran very well, no spoilage, moisutre content: $4 \%$ 
Hygroscopy of Dried Pulp. Hygroscopy is important because it relates to the storage stability, packaging needs, and handing requirements of dried foods. To study the hygroscopy of the dried rinsed-pulp (Trial 4) and the dried puree/paste (Trial 7), samples were placed in constant humidity rooms, and water uptake recorded as a gain in weight.

Two constant humidity rooms were used for the tests. The Tropical Room had $82^{\circ} \mathrm{F}$ dry bulb temperature and $80 \%$ relative humidity. The prairie Room had $70^{\circ} \mathrm{F}$ dry bulb temperature and 45 relative humidity.

In the hygroscopy test, petri dishes were tared, and $5 \mathrm{gm}$ samples of the dried product were weighed into the dishes. Six dishes ( 3 of dried pulp, and 3 of dried puree/paste) were placed in each room. The samples were weighed after $1,2,5$, and 8 days in the rooms. The result's, given as percent gain in weight versus storage time, are shown in Figs. 24 and 25 . 
$-83-$

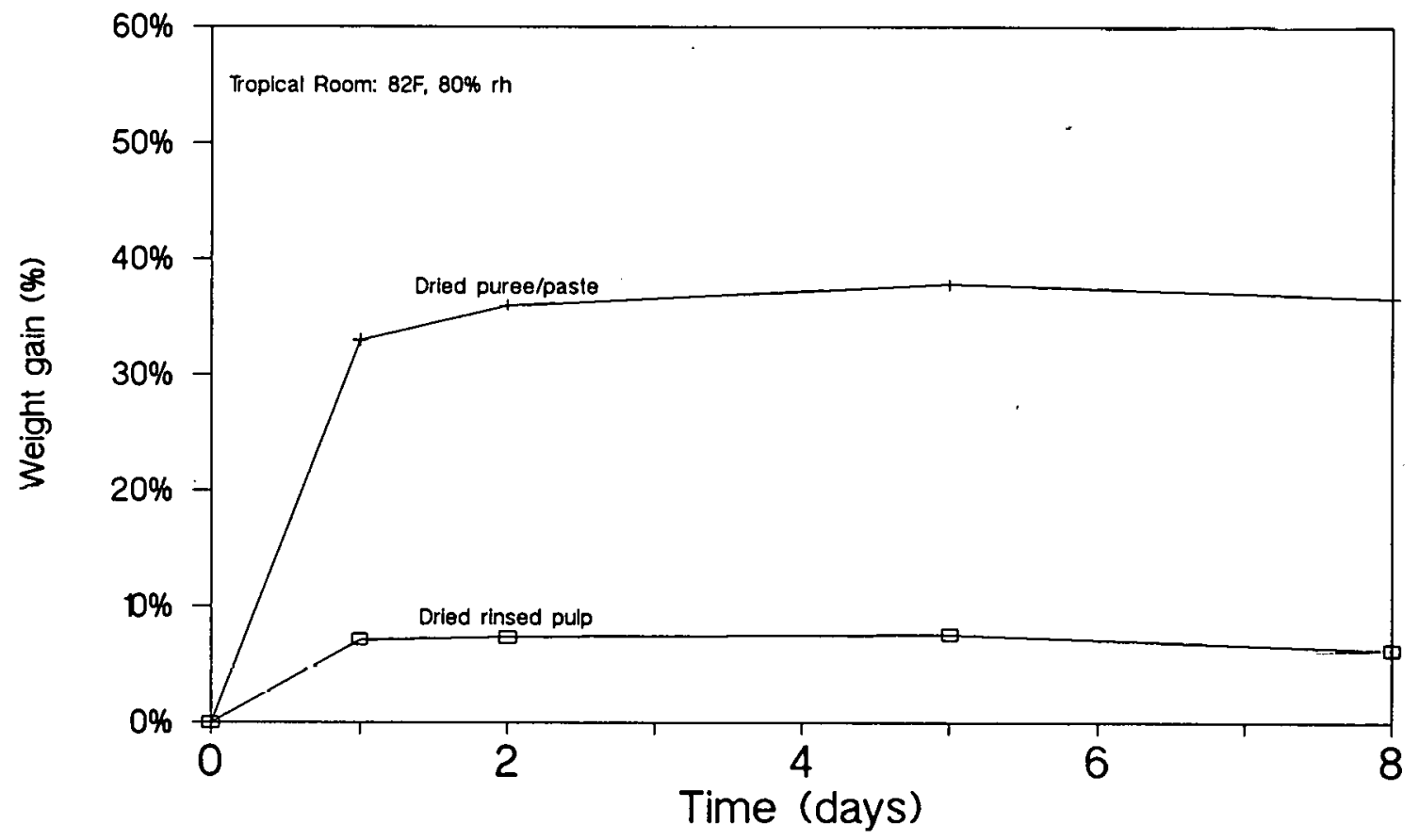

Figure 24 - Hygroscopy - weight gain ( $\%$ ) versus time in tropical room. 


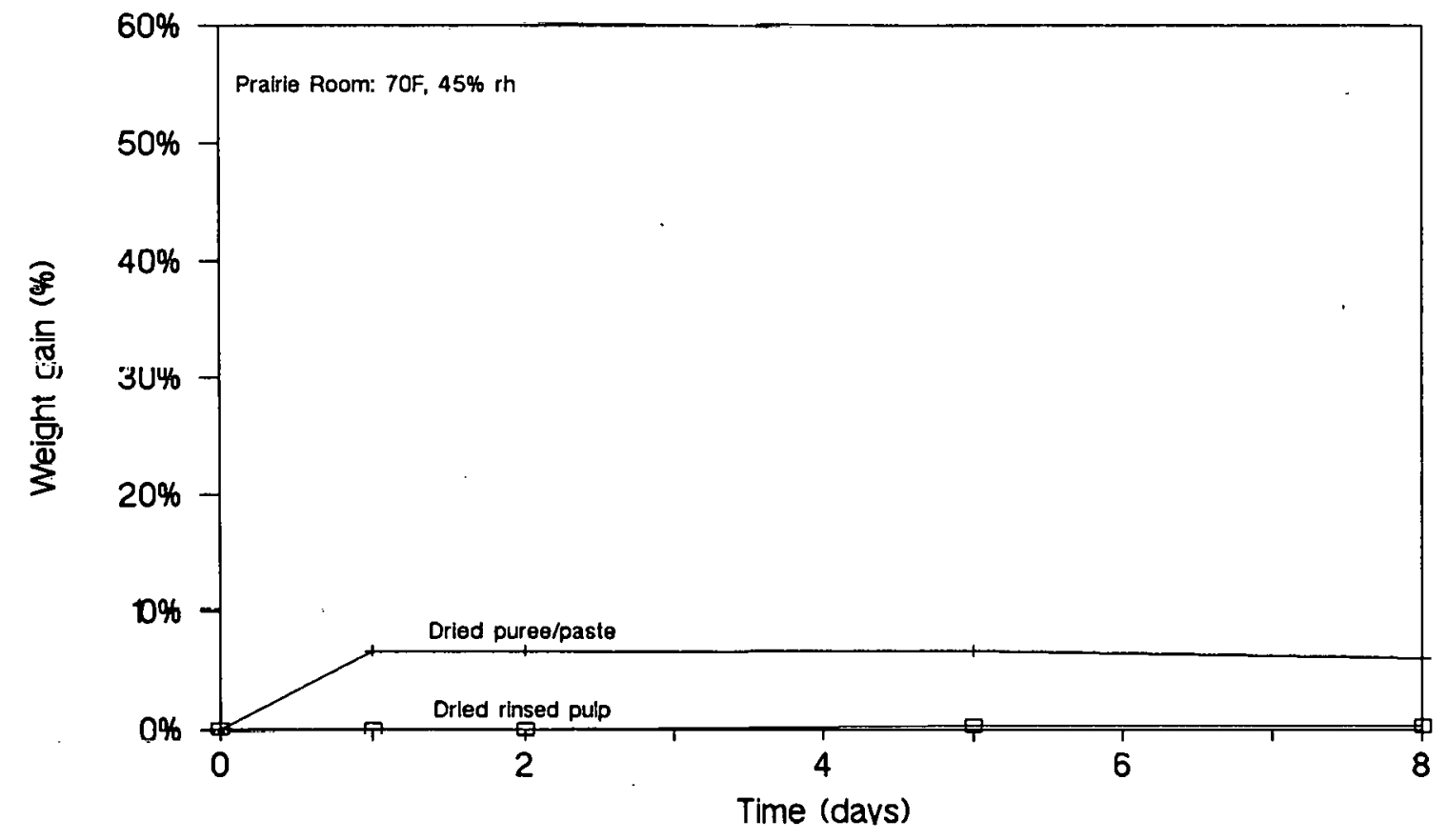

Figure 25 - Hygroscopy - Weight gain (\%) verșus time in. prairie room. 
This study showed the hygroscopy of rinsed-pulp to be low, especially when compared with dried puree/paste. Samples of puree/paste stored in the Tropical Room absorbed enough water to permit mold growth after 10 days. The difference in hygroscopy reflects the difference in sugar content between the two samples, since at low moisture content, sugar has a great water binding capacity.

\section{Fresh Juice studies}

In order to assess the effects upon fresh tomato juice of some of the techniques examined in this project, some studies were conducted with fresh product. For these studies fresh tomato juice (hot break: $210-200^{\circ} \mathrm{F}, 99-93^{\circ} \mathrm{C}$ ) was obtained from a food processing plant along with serum and pulp produced from a production scale decanter centrifuge operating on fresh tomato juice.

Puree Production. The Bostwick procedure to evaluate viscosity is commonly used in the tomato processing industry. Since it is not possible to perform this test on tomato juice, because it is too thin, a baseline puree was made from the fresh juice. This was done in order to have a quality baseline that would include Bostwick for comparison with later studies results.

Fresh juice $(4.9 \mathrm{lb}, 2.2 \mathrm{~kg})$ was concentrated using a rotary evaporator at $158^{\circ} \mathrm{F}, 70^{\circ} \mathrm{C}$ and $22^{\prime \prime} \mathrm{Hg}$ vacuum. The initial NTSS was 5.0. Four batches of this were run and composited producing a final puree with $9.1 \%$ NTSS. The puree was analyzed and results are in Table 26 .

Serum Concentration. It was necessary to concentrate the fresh juice serum to two solids levels. First, serum was needed at a solids level to be used for recombination to make puree; this 
TABLE 26. CHARACTERIZATION OF FRESH JUICE AND FRACTIONS

\begin{tabular}{|c|c|c|c|c|c|c|}
\hline $\begin{array}{l}\text { SAMPLE } \\
\text { I.D. }\end{array}$ & $\begin{array}{c}\text { TS } \\
\text { Vacuum } \\
q \\
\end{array}$ & $\begin{array}{c}\text { SS } \\
\text { Calc. } \\
8 \\
\end{array}$ & $\begin{array}{l}\text { IS } \\
\text { Calc. } \\
\text { \& }\end{array}$ & & $\begin{array}{c}\text { NTSS } \\
8 \\
\end{array}$ & $\begin{array}{c}\text { Pectin } \\
\frac{8}{8}\end{array}$ \\
\hline Juice & 5.86 & 4.78 & 1.08 & & 5.0 & 0.32 \\
\hline $\begin{array}{l}\text { Baseline } \\
\text { Puree }\end{array}$ & 10.59 & 8.59 & 2.00 & & 9.1 & -- \\
\hline Pulp & $\begin{array}{l}11.32 \\
11.09\end{array}$ & $\begin{array}{l}4.87 \\
4.88\end{array}$ & $\begin{array}{l}6.46 \\
6.21\end{array}$ & $\begin{array}{l}* 1 \\
\star 2\end{array}$ & $\begin{array}{l}5.4 \\
--\end{array}$ & 1.31 \\
\hline Serum & 4.83 & 4.83 & $\sim 0$ & & 4.9 & 0.18 \\
\hline $13 \%$ Serum & 12.76 & 12.58 & 0.18 & & 13.0 & -- \\
\hline $23 \%$ Serum & -- & -- & -- & & 20.8 & -- \\
\hline \multirow[t]{2}{*}{708 serum } & $\begin{array}{l}70.61 \\
71.92 \\
73.61\end{array}$ & $\begin{array}{l}\text { Calc. } \\
67.88 \\
68.81 \\
73.49\end{array}$ & $\begin{array}{l}2.93 \\
3.11 \\
0.13\end{array}$ & $\begin{array}{l}* \\
* 4 \\
* 5\end{array}$ & $\begin{array}{l}71.5 \\
-- \\
--\end{array}$ & $\begin{array}{l}-- \\
-- \\
--\end{array}$ \\
\hline & \multicolumn{3}{|c|}{$\begin{array}{l}* 1=\text { Whole Bucket } \\
\star 2=2 \text { nd Frozen Tub } \\
\text { * = Tub } 1\end{array}$} & \multicolumn{2}{|c|}{$\begin{array}{r}* 4=\text { Composite } \\
\text { Tub } 1 \text { and } \\
\text { analyzed } \\
\star 5=* 4 \text { analyze }\end{array}$} & $\begin{array}{l}\text { of rest of } \\
\text { ald Tub } 2 \\
\text { on } 9 / 25 / 86 \\
\text { ed on } 10 / 16 / 8\end{array}$ \\
\hline
\end{tabular}


would test whether separation alone affects quality. Then, serum was needed at a much higher solids level to be used for recombination to make puree; this would test whether separation and concentration affect quality. The highly concentrated serum would also be stored to assess shelf-stability.

Fresh juice serum ( $20 \mathrm{gal}, \sim 76 \mathrm{~L})$ was evaporated in a pilot scale evaporator at $\sim 160^{\circ} \mathrm{F}, \sim 70^{\circ} \mathrm{C}$ from $4.9 \%$ NTSS to $13 \%$ NTSS. Approximately $2.5 \mathrm{gal}, 9.5 \mathrm{~L}$ was removed from the evaporator for recombination testing. The rest of the serum still in the evaporator was concentrated to $20.8 \%$ NTSS and removed. Rotary evaporators were used $(\sim 3-4 \mathrm{hrs})$ at $\sim 160^{\circ} \mathrm{F}, \sim 70^{\circ} \mathrm{C}$ and $22 " \mathrm{Hg}$ vacuum to produce serum of $71.5 \%$ NTSS. Analysis results of fractions, juice, and puree are given in Table 26.

Recombination. The objective was to recombine the serum (at two solids levels) with pulp and water in order to assess the effect of separation, (concentration) and recombination upon quality. It was also necessary to produce enough of the puree made from low level solids serum to be used for a storage effect study.

Recombination with Low Level solids Serum.

Pulp (113.16 gm), 13\% TS serum (231.56 gm), and water (55.28gm) were combined to make $400 \mathrm{gm}$ puree, homogenizing for $7 \mathrm{~min}$. The NTSS ( $9.2 \%$ ) and TS by microwave (10.5\%) were measured to check solids levels against the baseline puree ( $9.1 \%$ NTSS, $10.3 \%$ TS). Since the solids were approximately the same as the baseline puree, larger batches were made using the same component ratios. Eleven batches (400 gms (a) were made with the homogenizer for 7 min each and composited (Sample No. 1, Table 27). One batch ( 12 $1 \mathrm{~b}, 5.4 \mathrm{~kg}$ ) was made using the static mixer with two passes through it (Sample No. 2, Table 27). A portion of each of these two batches was tested for solids and quality factors. The rest was used in a storage effect study. (See storage Effects.) 
TABLE 27. CHARACTERIZATION OF FRESH JUICE AND RECOMBINED SAMPLES

\begin{tabular}{|c|c|c|c|c|c|c|c|c|c|c|c|c|c|c|}
\hline \multicolumn{2}{|c|}{$\begin{array}{cc} & \\
\text { Sample } & \text { Sample } \\
\text { I.D. } & \text { No. } \\
\end{array}$} & $\begin{array}{l}\text { TS } \\
\vdots \\
\end{array}$ & $\begin{array}{l}\text { SS } \\
\circ \\
\end{array}$ & $\begin{array}{c}\text { Is } \\
\text { Calc. } \\
\vdots\end{array}$ & \multicolumn{2}{|c|}{$\begin{array}{l}\text { NTSS } \\
\frac{\%}{0}\end{array}$} & $\begin{array}{l}\text { Bost- } \\
\text { wick } \\
\mathrm{cm} .\end{array}$ & $L^{*}$ & $\begin{array}{l}\text { Color } \\
a^{\star}\end{array}$ & $s$ & $\begin{array}{r}\text { Std. } \\
L^{\star} \\
\end{array}$ & \multicolumn{2}{|c|}{$\begin{array}{l}\text { Color } \\
\text { Deviation }\end{array}$} & $\begin{array}{l}\text { Syner- } \\
\text { esis } \\
1 \mathrm{hr} \\
: \mathrm{Wt} .\end{array}$ \\
\hline $\begin{array}{l}\text { Baseline } \\
\text { Puree }\end{array}$ & & 10.59 & 8.59 & 2.00 & 9.1 & & 5.3 & 32.20 & 21.29 & 19.35 & 0.10 & 0.26 & 0.11 & 13.7 \\
\hline $\begin{array}{l}\text { Homog. } \\
\text { Puree }\end{array}$ & 1 & 10.53 & 8.68 & 1.90 & 9.2 & & 5.3 & 32.24 & 22.19 & $19.6 i$ & 0.11 & 0.16 & 0.12 & $11.2 \mathrm{~F}$ \\
\hline $\begin{array}{l}\text { Stat.Mix } \\
\text { Puree }\end{array}$ & 2 & 10.60 & 8.63 & 1.97 & 9.2 & & 5.67 & 32.06 & 22.09 & 19.22 & 0.13 & 0.17 & 0.17 & $11.5 F$ \\
\hline $\begin{array}{l}\text { HotF.1mo } \\
\text { Homog. }\end{array}$ & 3 & 11.5 & 9.15 & 2.00 & 9.62 & & 4.47 & 31.59 & $21.76^{\circ}$ & 19.30 & 0.1 .2 & 0.10 & 0.14 & 6.2 \\
\hline $\begin{array}{l}\text { HotF. } 4 \text { mo } \\
\text { Homog. }\end{array}$ & 4 & 11.12 & 9.07 & 2.05 & 9.77 & & 4.7 & 30.94 & 21.82 & 19.25 & $0.1 \overline{5}$ & 0.25 & 0.36 & 8.3 \\
\hline $\begin{array}{l}\text { HotF. } 8.5 \mathrm{mo} \\
\text { Homog. }\end{array}$ & 5 & $\mathrm{NA}$ & NA & $\mathrm{NA}$ & NA & & 4.5 & 31.51 & 21.26 & 19.23 & 0.11 & 0.10 & 0.09 & 10.1 \\
\hline $\begin{array}{l}\text { HotF.1mo } \\
\text { Stat.Mix }\end{array}$ & 6 & 11.17 & 9.16 & 2.01 & 9.67 & & 4.51 & 31.15 & 21.59 & ני18.9 & 0.16 & 0.10 & 0.15 & 8.0 \\
\hline $\begin{array}{l}\text { HotF. } 4 \mathrm{mo} \\
\text { Stat.Mix }\end{array}$ & 7 & 11.21 & 9.12 & 2.10 & 9.8 & & 4.36 & 30.74 & 21.57 & $18.8 \mathrm{~J}$ & 0.27 & 0.21 & 0.24 & 8.3 \\
\hline $\begin{array}{l}\text { HotF. } 8.5 \mathrm{mo} \\
\text { Stat.Mix }\end{array}$ & 8 & $\mathrm{NA}$ & $\mathrm{NA}$ & $\mathrm{NA}$ & $N A$ & & 4.25 & 31.30 & 21.21 & 19.10 & 0.11 & 0.11 & 0.14 & 10.3 \\
\hline \multirow[t]{2}{*}{$\begin{array}{l}\text { Homog. } \\
\text { Puree-0 }\end{array}$} & $\stackrel{9}{9}$ & 10.43 & 8.71 & 1.73 & 9.2 & \multirow[t]{2}{*}{$\begin{array}{l}\text { IN } \\
\text { JN } \\
\mathrm{HT}\end{array}$} & \multirow{2}{*}{$\begin{array}{l}6.0 \\
5.88 \\
8.0 \\
4.86\end{array}$} & 31.91 & 20.97 & 19.57 & 0.21 & 0.16 & 0.18 & $6.0 \mathrm{sF}$ \\
\hline & $\begin{array}{l}10 \\
(\text { Trial 2) }\end{array}$ & 10.87 & 8.72 & 2.15 & 9.2 & & & 31.04 & 21.22 & 19.13 & 0.11 & 0.14 & 0.12 & 5.7 \\
\hline $\begin{array}{l}\text { Stat.Mix } \\
\text { Puree-0 }\end{array}$ & 11 & 10.34 & 8.51 & 1.83 & 9.2 & & 6.45 & 30.69 & 20.54 & 18.60 & 0.18 & 0.18 & 0.16 & $11.5 \mathrm{sF}$ \\
\hline \multicolumn{3}{|l|}{$\begin{array}{l}\text { IN=initial } \\
\text { HT=heated }\end{array}$} & \multicolumn{6}{|c|}{$\begin{array}{l}\text { ON=Overnight } \\
\text { SF=Possibly slightly fermenting }\end{array}$} & \multicolumn{5}{|c|}{$F=$ Possibly fermenting } & \\
\hline
\end{tabular}


The solids of the recombined purees were nearly identical to the solids of the baseline puree. The Bostwick of the homogenized puree (mean of 4 determinations $=5.3 \mathrm{~cm}$ ) was the same as the baseline puree $\mathrm{cm}$ ) indicating no loss in viscosity. The Bostwick of the static mixed puree (mean of 3 determinations $=5.67 \mathrm{~cm}$ ) was slightly higher $\left(+0.37 \mathrm{~cm},+7 \frac{\circ}{6}\right)$ indicating a slight loss in viscosity.

The colors of the recombined purees were neither lighter nor darker (no change in $L^{*}$ ), and had slightly more red/purple (higher $a^{*}$ ) than the baseline puree.

Syneresis results of homogenized (11.25\%) and static mixed (11.5\%) purees were slightly lower than the baseline puree (13.7\%) indicating no significant increase in syneresis or serum separation. There was some gas formation in the two recombined samples during the five hour test indicating possible fermentation. These samples had been refrigerated for four days before the syneresis test.

The results of these tests indicate that separation by centrifuge, and recombination by homogenizer does not adversely affect viscosity (Bostwick), color, or syneresis. Recombination by static mixer does not appear to adversely affect color or syneresic, but the bostwick viscosity is not fully recovered.

Recombination with High Level Solids Serum.

Trial 1 - Pulp $(226.3 \mathrm{gm}), 70 \%$ TS serum $(83.7 \mathrm{gm})$, and water $490.0 \mathrm{gm}$ ) were combined to make $800 \mathrm{gm}$ puree, homogenizing for 7 min (Sample 9, Table 27). This recombination procedure was repeated with the same ratios of each component, using the static mixer ( 2 passes) making $950 \mathrm{gm}$ puree (Sample 11, Table 27). The samples were tested for solids and quality factors. 
The total solids of the recombined purees (10.43 and $10.34 \%$ ) were slightly lower than that of the baseline puree (10.59\%). The Bostwick viscosity of the homogenized puree (mean of five determinations) was higher $(6.0 \mathrm{~cm})$ than the baseline puree $(5.3 \mathrm{~cm})$ indicating a slight viscosity loss $(+0.7 \mathrm{~cm},+13 \%)$. The Bostwick of the static mixed puree (mean of three determinations) was also higher $(6.45 \mathrm{~cm})$ than the baseline puree, indicating a viscosity loss $(+1.15 \mathrm{~cm},+22 \%)$. The samples were refrigerated overnight and the homogenized sample (No. 9) was tested for Bostwick. There was a slight improvement $(5.88 \mathrm{~cm})$. Both samples were heated to $92^{\circ} \mathrm{C}$, cooled, and tested for Bostwick giving poorer results $(8.0$ and $7.9 \mathrm{~cm})$. The lower viscosity values may have been related to the lower solids values; thus a second trial was made.

The color of the static mixed recombined sample (No. 11) was darker (lower $L^{*}$ ), and had slightly less red/purple (lower a*) and less yellow (lower $b *$ ) than the baseline puree. The color of the homogenized sample (No. $y$ ) was nearly the same as the baseline puree.

syneresis results of the homogenized puree (6.0\%) were signif1cantly lower than the baseline puree (13.7\%). The static mixed puree (11.5\%) was approximately the same as the baseline puree. There was some gas formation in the two recombined samples during the latter part of the five hour test. This might indicate fermentation, however chemical analysis revealed no alcohol or lactic acid, possible fermentation products.

Trial 2 - Pulp (128.0 gm), $70 \%$ TS serum $(28.2 \mathrm{gm})$, and water $(233.7 \mathrm{gm})$ were combined to make $400 \mathrm{gm}$ puree, homogenizing for 7 min (Sample 10, Table 27). The sample was tested for solids and quality factors. 
This time the total and insoluble solids of the homogenized puree (10.87 and $2.15 \%$ ) were slightly higher than that of the baseline puree $(10.59$ and $2.0 \%)$. The Bostwick viscosity of the homogenized puree (mean of 3 determinations) was lower $(4.86 \mathrm{~cm}$ ) than the baseline puree $(5.3 \mathrm{~cm})$ indicating a slight viscosity gain $(-0.44 \mathrm{~cm}, 8 \%)$. If the recombination could reproduce the actual baseline solids, the baseline Bostwick value could probably also be reached. Quantity limitation prevented a third trial:

The color of sample 10 was slightly darker than the baseline puree.

Syneresis of the Trial 2 homogenized puree (5.7\%) was lower than the baseline puree $(13.7 \%)$.

The results of these tests indicate that separation by centrifuge, concentration of serum to a high level, and recombination by homogenization will most likely give a puree with adequate viscosity, less serum separation, and slightly darker color. The total and insoluble solids content of the recombined product is critical. to its viscosity. Since the static mixed recombination was not repeated, it is difficult to draw firm conclusions about its quality.

stonage Effecta. The effect of time upon both recombined product and high level solids serum was studied.

Recombined Product storage.

As mentioned previously, some of the recombined puree made with low level solids serum was used in a storage effect study, to see what effect separation and recombination would have upon the long term quality of the recombined product. 
Sixteen \#303 cans were filled with recombined product which had been heated to $190^{\circ} \mathrm{F}, 88^{\circ} \mathrm{C}$. The cans were refrigerated to prevent flat sour spoilage. Eight cans contained static mixed product; eight cans contained homogenized product (one of these cans was only half full). The cans were stored for subsequent opening at various time intervals for product quality assessment.

At 1 month two cans of each recombination technique were opened and composited. Analysts resulls are in Table. 27 (Sample Nos. 3 and 6 ). The solids of these two purees were higher than those of the baseline puree because of the evaporation which took place while heating the recombined purees prior to filling the cans. The Bostwick viscosity determination gave similar results for both products $(4.47 \mathrm{~cm}, \mathrm{~s} . \mathrm{d} .=0.01$ [the mean of 3 determinations] for the homogenized; $4.51 \mathrm{~cm}, \mathrm{s.d}=0.16$ [the mean of 8 determinations] for the static mixed). These values show an increase in viscosity $(\sim-0.8 \mathrm{~cm}, 15 \%)$ over the baseline puree $(5.3$ $\mathrm{cm})$ which is at least partly due to the increase in solids ( $0.6 \%$ TS increase). The Bostwick of the static mixed puree was approximately the same as that of the homogenized puree, which is significant since these two values differed $(0.37 \mathrm{~cm}, 7 \%)$ prior to heating and holding.

The hot filled purees had higher solids than the baseline puree. This, in addition to the heat treatment, may account for their darker colors (lower $L^{*}$ ). The static mixed hot filled puree (Sample No. 6) had slightly less yellow color (lower $b *$ ).

Syneresis results are better (lower) than the baseline puree and the recombined purees prior to heating and holding. Some of this may be due to the increase in solids content, and some may be due to the heat treatment. 
At 4 months two cans of each recombination technique were opened and composited. Analysis results are in Table 27 (Sample Nos. 4 and 7). The Bostwick viscosities were similar to those at 1 mo. The colors of both recombined products were slightly darker than at 1 mo, but there were no other significant changes in color. The syneresis results showed a slight increase in serum separation, but the values were less than the original baseline puree.

At 8.5 months two cans of each recombination technique were opened and composited. Analysis results are in Table 27 (Sample Nos. 5 and 8 ). The Bostwick viscosity values of the recombined products were similar to or lower than those at 1 and 4 months. Colors of the recombined products at 8.5 months were similar to the color at 1 month. Syneresis results were higher than at. 1 and 4 months, but lower than the baseline puree.

These storage effect results indicate acceptable. storage capability. Provision should be made in subsequent testing to assess storage of the product at temperature(s). commonly used for product storage $\left(70^{\circ} \mathrm{F}\right)$.

High Level Solids Serum storage.

The $72 \%$ solids serum was stored at room temperature in a plastic tub for 8 momths. There was no sign of mold growth. The outer. layer appears darker in color than the inner portion.

Ultrafiltration of serum. The same 100,000-MW-cutoff ultrafiltration membranes that had been used with rinse/serum were used for testing with fresh juice serum.

Two batch separation runs were made and data is summarized in Table 28 and Figs. 26 and 27. All runs were made at 100 psi (0.7. MPa), $8 \mathrm{~L} / \mathrm{min}$, and $25^{\circ} \mathrm{C}$ (except during the two temperature scans 
in the second batch) with $0.108 \mathrm{~m}^{2}$ membrane area each of two membrane types (GR4OPP and PES100). Each run began wth an hour run time in recycle mode, to monitor initial flux. This showed that flux decline was time dependent as well as concentration dependent. After the first batch, the membranes were cleaned with an enzyme detergent (Monarch DDS).

During the second batch, temperature scans followed the initial recycle period $\left(25-65^{\circ} \mathrm{C}\right)$ and the batch separation $\left(25-65^{\circ} \mathrm{C}\right)$ (Table 29). At the higher temperatures, as in the tests run wlll rinse/serum, sugar rejection (by NTSS) was lower and the flux significantly higher.

The flux with fresh juice serum was in the same range as that with the rinse/serum but was somewhat lower, possibly for the following reasons: the initial fresh juice serum feed had a higher osmotic pressure, due to its higher concentration, ( $5 \%$ NTSS) than the initial rinse/serum feed ( $4 \%$ NTSS); the membranes had operated previously for $29 \mathrm{hr}$ before operating on fresh juice serum.

The flux from both membrane types was very similar even though the PES100 membranes were operating at a lower pressure (since they were on the outlet end of the module). Sugar rejection with the PES100 membranes was lower than with the GR4OPP membranes. The lower rejection, a desirable characteristic, may be related to the lower operating pressure of the PES100 membranes, or the characteristics of the membrane. Reversing the order of the membranes on the module could test whether the lower operating pressure was the cause of the lower rejection.

During the runs with fresh juice serum, 53-57\% of the sugar permeated and 55-60\% of the organic acid permeated. The final retentate weight was $37-41 \%$ of the initial feed weight. The runs 
with rinse/serum permeated more sugar (65-74\%) and acid (66-77\%), and produced a lower retentate weight (17-28\% of the initial feed weight). The runs with fresh juice serum could not reach the lower retentate weight reached with rinse/serum. This may have been due to the higher pressure drop across the membranes which occurred at the beginning of the runs with fresh juice serum $(62$ and 80 psi) versus the initial pressure drop with rinse serum $(32,43,52$, and 62 psi), (Figs. 19 and 28) which built up with operation time. 
TABLE 28. 100,000-IWW-CUTOFF MEMRRANE ULTRAFILTRATION TESTING WITH FRESH JUICE SERUM

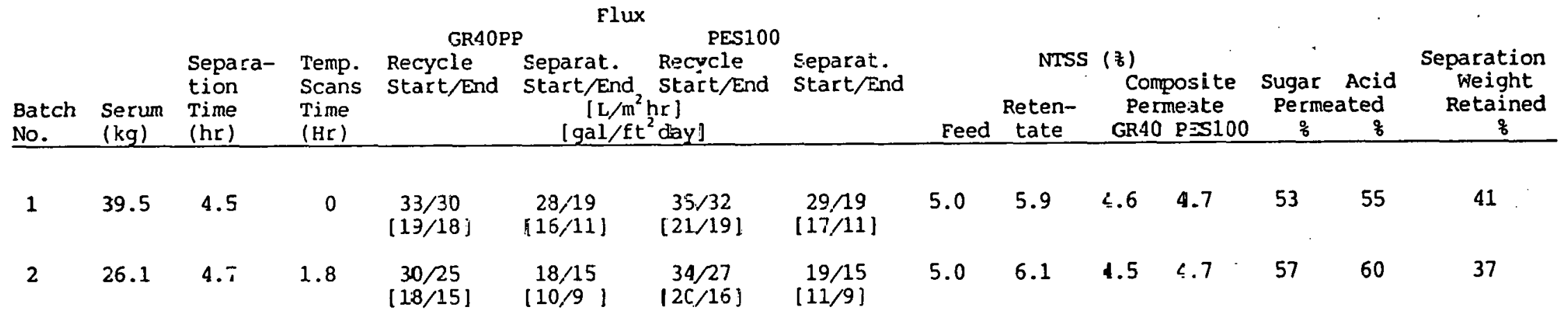




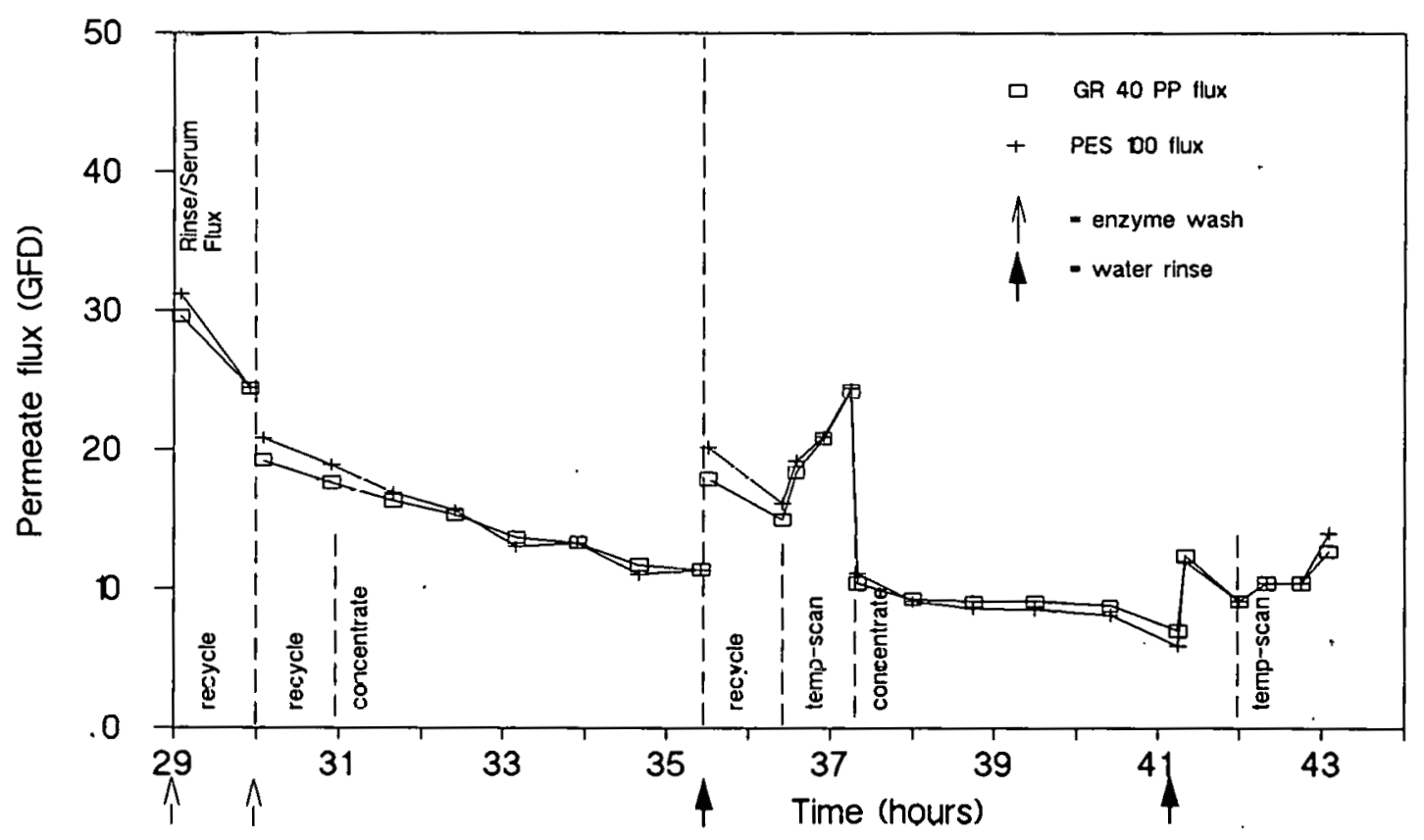

Figure 26 - Flux versus time - 100,000-MW-cutoff membrane ultrafiltration of fresh juice serum. 


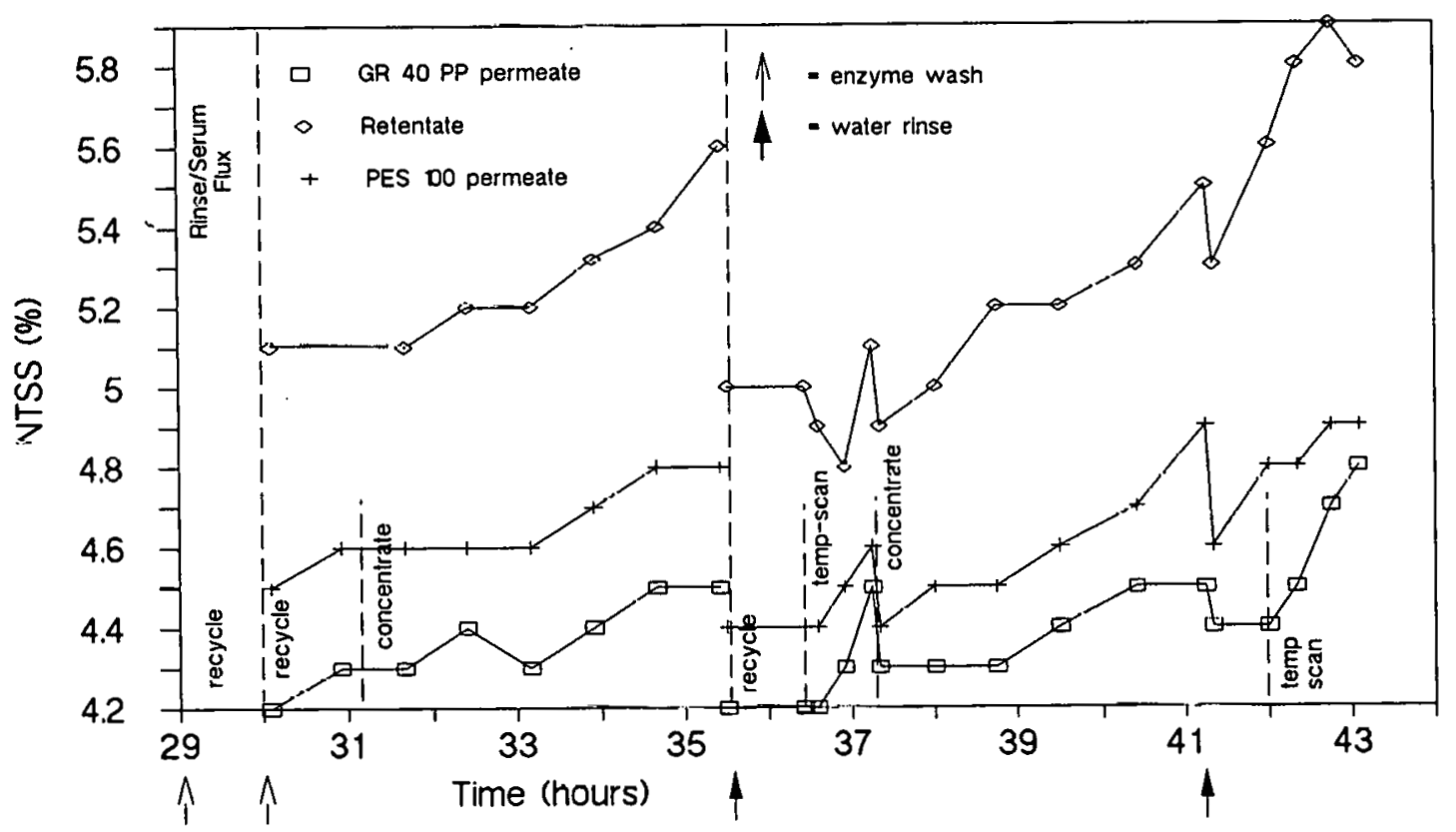

Figure 27 - NTSS (\%) versus time - 100,000-MW-rutoff membrane ultrafiltration of fresh juice serum. 
TABLE 29. 100,00-MW-CUTOFF MEMBRANE ULTRAFILTRATION TEMPERATURE SCANS WITH FZESH JUICE SERUM

\begin{tabular}{|c|c|c|c|c|c|c|c|c|}
\hline \multirow{2}{*}{$\begin{array}{l}\text { Batch } \\
\text { No. } \\
\frac{2}{2}\end{array}$} & \multirow{2}{*}{$\begin{array}{l}\begin{array}{l}\text { Serum } \\
(\mathrm{kg})\end{array} \\
26.1\end{array}$} & \multirow{3}{*}{$\begin{array}{l}\text { Scan } \\
\text { Timing } \\
\\
\text { After } \\
\text { Recycle }\end{array}$} & \multirow{3}{*}{$\begin{array}{l}\text { Temp. } \\
\left({ }^{\circ} \mathrm{C}\right)\end{array}$} & \multirow{2}{*}{\multicolumn{2}{|c|}{$\begin{array}{c}(\mathrm{L} / \mathrm{m} 2 \mathrm{hr}) \\
{[\mathrm{gal} / \mathrm{ft} 2 \mathrm{day}]}\end{array}$}} & \multirow{3}{*}{$\begin{array}{l}\begin{array}{l}\text { Reten- } \\
\text { tate }\end{array} \\
\\
5.0 \\
4.9 \\
4.8 \\
5.1\end{array}$} & \multicolumn{2}{|c|}{$\begin{array}{l}\text { WTSS }(\%) \\
\text { Permeate }\end{array}$} \\
\hline & & & & & & & GR4OPP & PES100 \\
\hline 2 & 26.1 & & & $\begin{array}{l}23[15] \\
31[18] \\
35[21] \\
41[24]\end{array}$ & $\begin{array}{l}27[16] \\
33[19] \\
36[21] \\
41[24]\end{array}$ & & $\begin{array}{l}4.2 \\
4.2 \\
4.3 \\
4.5\end{array}$ & $\begin{array}{l}4.4 \\
4.4 \\
4.5 \\
4.6\end{array}$ \\
\hline & & $\begin{array}{c}\text { After } \\
\text { Separation }\end{array}$ & $\begin{array}{l}25 \\
38 \\
48\end{array}$ & $\begin{array}{l}15[9] \\
18[10] \\
18[10]\end{array}$ & $\begin{array}{l}15[9] \\
18[10] \\
18[10]\end{array}$ & $\begin{array}{l}5.6 \\
5.8 \\
5.9\end{array}$ & $\begin{array}{l}4.4 \\
4.5 \\
4.7\end{array}$ & $\begin{array}{l}4.8 \\
4.8 \\
4.9\end{array}$ \\
\hline
\end{tabular}




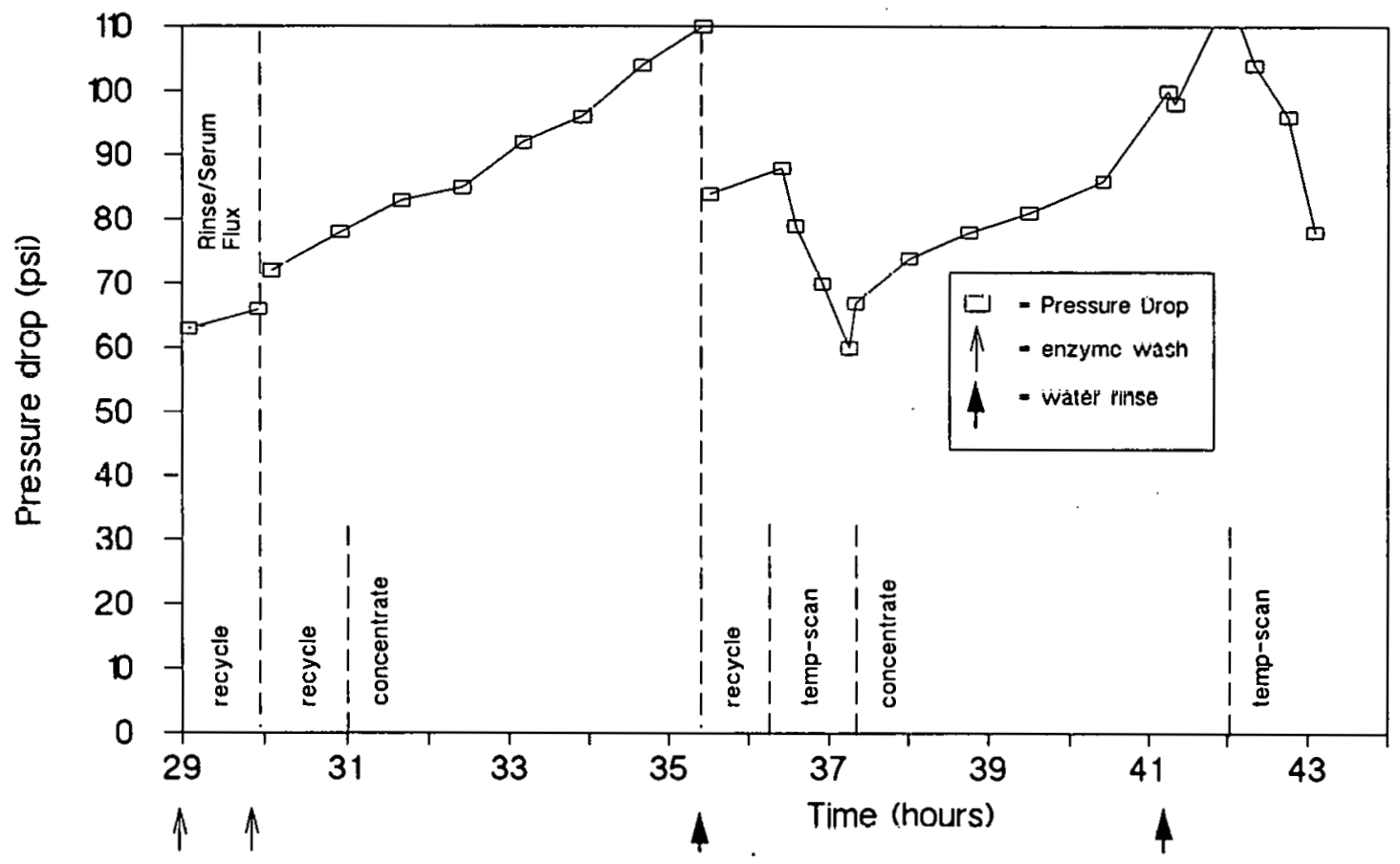

Figure 28 - Pressure drop vereus time - 100,000-MW-cutoff membrane ultrafiltration of fresh juice serum. 


\section{CONCLUSIONS AND RECOMMENDATIONS}

Tomato puree was successfully separated by centrifuge into pulp and rinse/serum fractions. Rinse/serum was successfully fractionated into high-, intermediate-, and low-Mw fractions. Further study on the performance economics of the ultrafilter is recommended. Fractions were successfully concentrated ( rinse/serum [to $13 \% \mathrm{TS}$ ] and low/intermediate-MW fraction [to $74 \%$ TS] and recombined by homogenizer to produce a puree. The recombined puree had satisfactory viscosity and was lighter in color than the control puree. Ion exchange successfully produced sugar and organic acid fractions from the low-mw fraction. Further work is needed to demonstrate the possibility of recombining using the sugar and organic acid fractions.

Fresh tomato juice was successfully separated by centrifuge into pulp and serum fractions. The serum was successfully concentrated to two levels ( 13 and $70 \% \mathrm{TS}$ ) and recombined with pulp and water to produce a puree by homogenization and by static mixing. The homogenized recombined puree had satisfactory viscosity at both serum concentration levels; the static mixed recombined puree had satisfactory viscosity at the lower serum concentration level. The recombined puree was darker in color than the control puree at the higher serum concentration level, and the same color as the control puree at the lower serum concentration level. It is recommended that a storage study of fractions and recombined product be conducted at ambient.. temperature.

Performance of host site studies is recommended. 


\section{REFERENCES}

AOAC, 1984. "Official Methods of Analysis," 14th ed. Association of Official Analytical Chemists, Washington, D.C.

Blumenkrantz, N. and Asboe-Hansen, G., 1973. New method for quantitative determination of uronic acids. Anal. Biochem. $54: 484$.

Chin, H., Kimball, J., Hung, J., and Allen, B., 1985. Microwave oven drying determination of total solids in processed tomato products; a collaborative study. J. Assoc. Off. Anal. Chem. $68(6): 1081$.

Lamb, F. C., 1969. Collaborative study of the determination of soluble solids in tomato products by refractive index expressed as per cent sucrose. J. Assoc. Off. Anal. Chem. $52: 1050$.

Loftness, R. L., 1978. "Energy Handbook," Van Nostrand Reinhold So., New York, NY.

NCA, 1968. "Laboratory Manual for Food Canners and Processors, volume Two." AVI Publishing Co., Inc., Westport, СT.

McCready, R.M. and McComb, E.A., 1952. Extraction and determination of total pectic materials in frutts. Anal. Chem. 24(12): 1986 .

Southgate, D.A.T., 1969. Determination of carbohydrates in foods. J. Sci. Food Agric. 20:326.

Stoforos, N., 1986. Private communication. U.C. Davis, Davis, CA. 
APPENDIX A

\section{ABBREVIATIONS}

Btu

${ }^{\circ} \mathrm{C}$

cm

CP

$\circ F$

ft

gal

$\mathrm{gal} / \mathrm{ft} \mathrm{t}^{2} \mathrm{day}$

$\mathrm{gal} / \mathrm{min}$

$\mathrm{gm}$

$\mathrm{h}$

hr

hp

in

$\mathrm{J}$

K

$\mathrm{kg}$

$\mathrm{kJ}$

L

Ib

$\mathrm{L} / \mathrm{m}^{2} \mathrm{hr}$

$\mathrm{L} / \mathrm{min}$

m

$\mathrm{mPa}$

$\mathrm{MPa}$

psi

rpm

$\mathbf{s}$

W

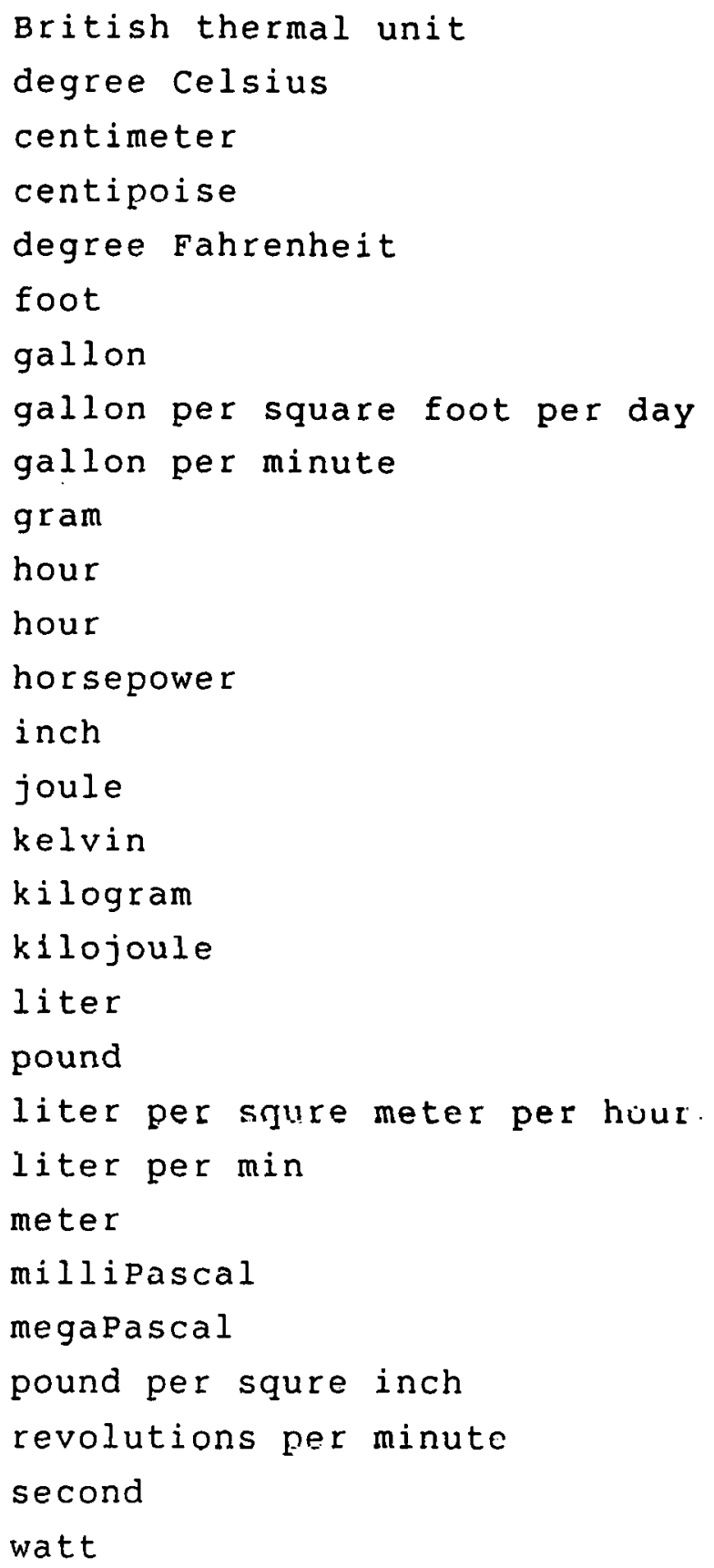




\section{APPENDIX B}

METRIC TO ENGLISH CONVERSION TABLE

To Convert From
$\mathrm{L} / \mathrm{m}^{2} \mathrm{hr}$
$\mathrm{har}$
$\mathrm{mPa}$
$\mathrm{MPa}$
$\mathrm{L}$
$\mathrm{L} / \mathrm{min}$
$\mathrm{Cm}$
$\mathrm{m}$
$\mathrm{m}$
$\mathrm{cm}$
$\mathrm{m}^{2}$
$\mathrm{Hl}^{3}$
$\mathrm{~m}^{3}$
$\mathrm{gm}$
$\mathrm{kg}$
$\mathrm{kg}$
$\mathrm{w}$
$\mathrm{J}$
$\mathrm{kJ}$

To

$g a l / f t^{2} d a y$

psi

psi

psi

gal

gal/min

in

in

$\mathrm{ft}$

in ${ }^{2}$

$f t^{2}$

$f t^{3}$

gal

$1 \mathrm{~b}$

$1 \mathrm{~b}$

$t$

$\mathrm{hp}$

kwh

Btu
Multiply By

$5.891 \times 10^{-1}$

$1.45 \times 10^{1}$

$1.15 \times 10^{-7}$

$1.45 \times 10^{2}$

$2.042 \times 10^{-1}$

$2.642 \times 10^{-1}$

$3.937 \times 10^{-1}$

$3.937 \times 10^{1}$

3. 2808

$1.55 \times 10^{-1}$

$1.0764 \times 10^{1}$

$3.5313 \times 10^{1}$

$2.642 \times 10^{2}$

$2.2046 \times 10^{-3}$

2. 2046

$1.023 \times 10^{-3}$

$1.3405 \times 10^{-3}$

$2.7778 \times 10^{-7}$

$9.478 \times 10^{-1}$ 